


\section{ADB and Thailand}

A Development Partnership toward Inclusive Growth
(1) 2017 Asian Development Bank

6 ADB Avenue, Mandaluyong City, 1550 Metro Manila, Philippines

Tel $+6326324444 ;$ Fax +6326362444

www.adb.org

Some rights reserved. Published in 2017.

Printed in Thailand.

ISBN 978-92-9257-798-8 (e-ISBN)

Publication Stock No. ARM178706-2

DOI.http://dx.doi.org/10.22617/

The views expressed in this publication are those of the authors and do not necessarily reflect the views and policies of the Asian Development Bank (ADB) or its Board of Governors or the governments they represent. By making any designation of or reference to a particular territory or geographic area, or by using the term "country" in this document, ADB does not intend to make any judgments as to the legal or other status of any territory or area.

This work is available under the Creative Commons Attribution 3.01 IGO license (CC BY 3.0 IGO) https://creativecommons.org//icenses/by/3.0//igo/. By using the content of this publication, you agree to be bound by the terms of this license.

This CC license does not apply to non-ADB copyright materials in this publication. Please contact pubsmarketing@adb.org if you have questions or comments with respect to content or permission to use. Notes:

In this publication, "\$" refers to US dollars.

Corrigenda to ADB publications may be found at http://www.adb.org/publications/corrigenda

All photos are from $A D B$ unless otherwise specified. 


\section{CONTENTS}

FOREWORD

TIMELINE

PART I: HISTORY OF THE PARTNERSHIP

INTRODUCTION

EARLY HISTORY OF THE ASIAN DEVELOPMENT BANK

ADB AND THAILAND

Industrial Finance: ADB's First Loan

Electricity Generation and Distribution

Transport Infrastructure

Water Supply and Wastewater Management

Agriculture and Fisheries

Summary

THE 1997 FINANCIAL CRISIS

SUMMARY

PART II: A DECADE OF PARTNERSHIP THROUGH THAILAND RESIDENT MISSION

ESTABLISHMENT OF ADB'S THAILAND RESIDENT MISSION

COUNTRY PARTNERSHIP STRATEGY BETWEEN ADB AND THAILAND,

2005 TO THE PRESENT

Climate Change Mitigation and Environment

Energy Efficiency

Clean Energy

Solar Power

Irastructure

Road Systems

Rail Systems

State Railway of Thailand

Mlass Rapid Transit System

Finance Sector

Capital Markets Development Program

Financial Inclusion

Regional Cooperation and Integration

ADB-Thailand Partnership in the Subregional Economic Cooperation Program

ADB-Thailand Partnership as a Regional Development Partner

PART III: TOWARD THE FUTURE

LESSONS LEARNED

CHALLENGES

THE WAY FORWARD 


\section{LIST OF TABLES, FIGURE, AND BOXES}

Tables

1 Gross Domestic Product per Capita in Selected Asian Countries, 1965 and 2015

2 ADB Loans to the Industrial Finance Corporation of Thailand, 1968-1983

3 ADB Loans to the Power Sector in Thailand, 1973-1996

4 ADB Support to the Transport Sector in Thailand, 1974-1995

5 ADB Support for Water Supply and Wastewater Management in Thailand, 1993-1997

6 ADB Support for the Agriculture and Fisheries Sectors, 1974-1999

7 ADB Support to Thailand in Response to the 1997 Asian Financial Crisis

8 Technical Assistance to Thailand since Inauguration of ADB's Thailand Resident Mission

9 Energy Consumption in Thailand, 2013

10 ADB Cumulative Lending, Grants, and Technical Assistance by Sector,

and Nonsovereign Financing, 1966-2016

Figure

1 Average Life Expectancy in Selected Asian Countries, 1965 and 2015
Boxes
The Rural Enterprise Credit Project
2 Agriculture Sector Program
3 Social Sector Program
4 Infrastructure Development
5 Capital Markets Development
6 Environmentally Sustainable Development
7 Regional Cooperation and Integration
8 Greater Mekong Subregion Highway Expansion Projects
9 Financial Literacy
10 Greater Mekong Subregion
11 Neighbouring Countries Economic Development Cooperation Agency
12 Thailand International Development Cooperation Agency 


\section{FOREWORD}

When the Asian Development Bank (ADB) was formed in 1966, Asia ws contending with widespread poverty and food shortages, and Thailand was stil low-income country. Over the past 50 years, $A D B$ is proud to have participate Pacific region. Thalland was one of ADB's founding member countries, and 1968, ADB provided its very first loan to Thailand for onlending to industral enterprises, laying the foundation for the country's industrial development during the 1970s.

The partnership between ADB and Thailand has involved both financial an echnical cooperation in a wide range of sectors including infrastructure, Anance, energy, environment, and reglonal cooperation and integration. 2005 , when ADB's Thalland Resident Mission was inaugurated in Banglok Thailand had already achieved middle-income status. Yet even with Thailand's advancement, ADB has continued to serve as an important conduit through which Thai public and private sector institutions gain access to the financial support, knowledge and cutting-edge expertise that are essential to the country's growing and increasingly sophisticated development. Today The stitutional and operational capacity, and the strengthening of Thailand's International competitiveness.

This publication, ADB and Thailand: Development Partnership toward Inclusive Growth, reflects on Thailand's impressive development journey over the

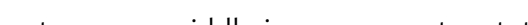

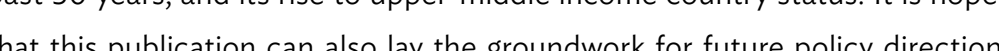
he We france, $A D B$ will continue to support sustainable and inclusive growth in Thailand through cleaner and more technologically advanced infrastructure 作elopment, Public-Private Partnerships, climate-friendly innovations, and gional cooperation and integration.

On the occasion of ADB's 50-year anniversary, we look forward to workin more closely with Thailand as the country continues to navigate the path of development
Since joining ADB as a founding member in 1966, Thailand has experienced drastic improvements in economic and social development with Gross Domestic Product per capita increasing by 42 folds. In essence, the Tha economy has transformed from agricultural-based (Thailand 1.0) to lightnuustrial-based (Thailand 2.0) and now to heavy-industrial-based (Thailand 3.0).

Going forward, on the economic front, the Thai government has recent/y adopted Thailand 4.0 initiative with focuses on innovation and services economy. The shift toward a value-based economy by promoting knowledgeand-innovative-based economic activities, inclusive society and environmenta sustainability can promote inclusive and equal opportunities to all which w eventually improve the overall living condition of Thai people as a whole.

Over the course of our partnership, ADB has been constantly supported Thailand's economic transformation. Development loans and technical assistances have greatly contributed to our efforts to strengthen economic and social foundation. The cooperation between ADB and Thalland has broug th about many development success stories not only in infrastructure and region development projects but also in health, education and agricultural sectors.
The critical role of $A D B$ as a resional development partner, especillly in the Greater Mekong Subregion, has greatly contributed to regional integration to promote equitable development not only in infrastructure connectivity but region

As one of the fastest growing developing countries, Thailand is now a donor member in Asian Development Fund. Moreover, the close collaboration has been elevated by the establishment of ADB's Resident Mission in Thailand in 2005 to intensify its operation within the region using Thailand as the base. this publication, $A D B$ and Thailand: Development Partnership toward Inclusive Growth, highlights many success stories and examples of our long-term partnership which, I think, can benefit other members in terms of lesson learned. Thailand looks ahead to continue its close collaboration with $A D B$ to transform itself into a value based economy and to pursue its high-income country status.

One occasion of ADB's 50th anniversary, I wish ADB all the success in its Sustainable Development Goals and to ensure that " $n$ o one will be left behind."

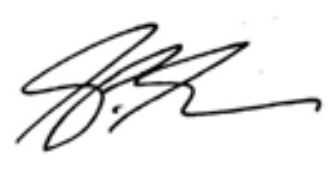

Stephen P. Groff

Vice-President
Asian Development Bank 


\section{TIMELINE}

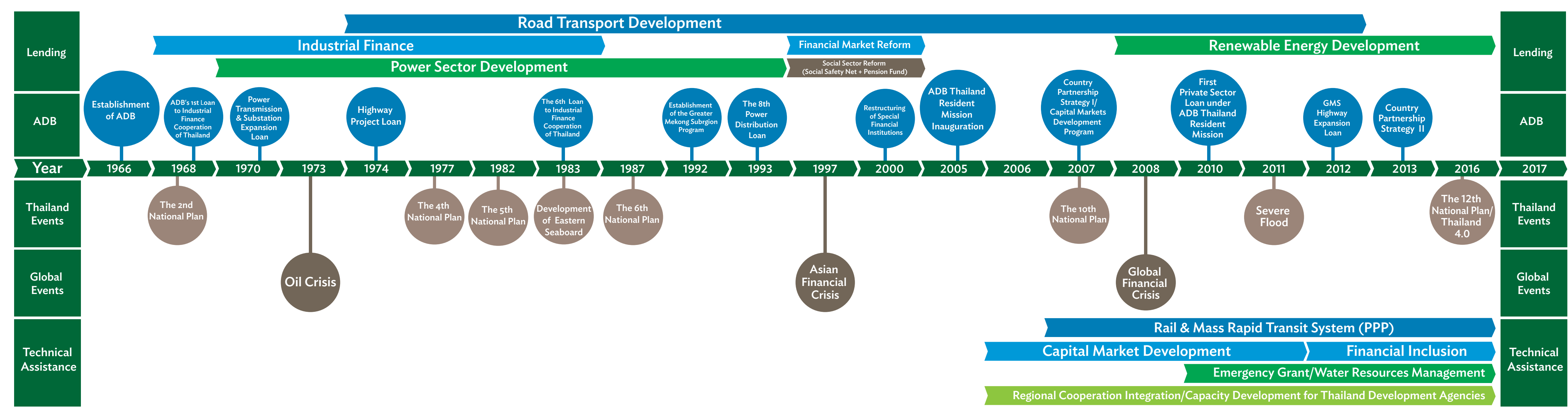




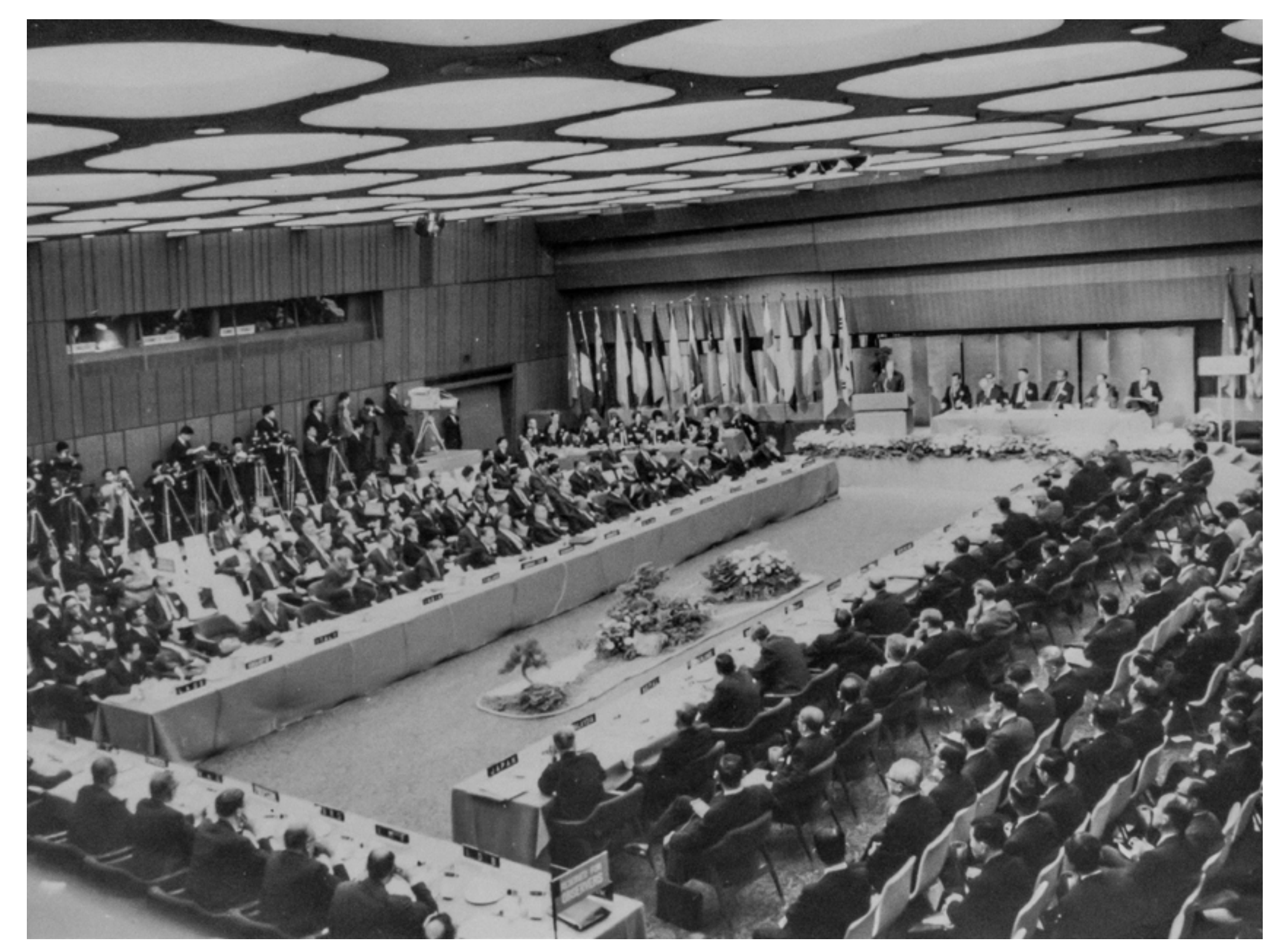

\begin{tabular}{l|c|c|c|} 
& \multicolumn{2}{l|}{ GDP: Capita (current \$) } & Increase (multiple) \\
\hline Country & 1965 & 2015 & $1965-2015$ \\
\hline Lao PDR & - & 1,810 & - \\
\hline Indonesia & 56 & 3,350 & $60 x$ \\
\hline PRC & 97 & 9,720 & $100 x$ \\
\hline Rep. of Korea & 105 & 27,200 & $259 x$ \\
Viet Nam & 126 & 2,110 & $17 x$ \\
Cambodia & 134 & 1,160 & $9 x$ \\
\hline Thailand & 138 & 5,820 & $42 x$ \\
\hline Philippines & 187 & 2,900 & $16 x$ \\
Malaysia & 309 & 9,770 & $32 x$ \\
Singapore & 516 & 52,900 & $103 x$ \\
Myanmar & 589 & 1,203 & $2 x$ \\
Japan & 920 & 32,500 & $35 x$ \\
Brunei Darussalam & 1,110 & 36,600 & $33 x$ \\
United Kingdom & 1,851 & 43,700 & $24 x$ \\
United States & 3,830 & 55,800 & $15 x$ \\
& & &
\end{tabular}




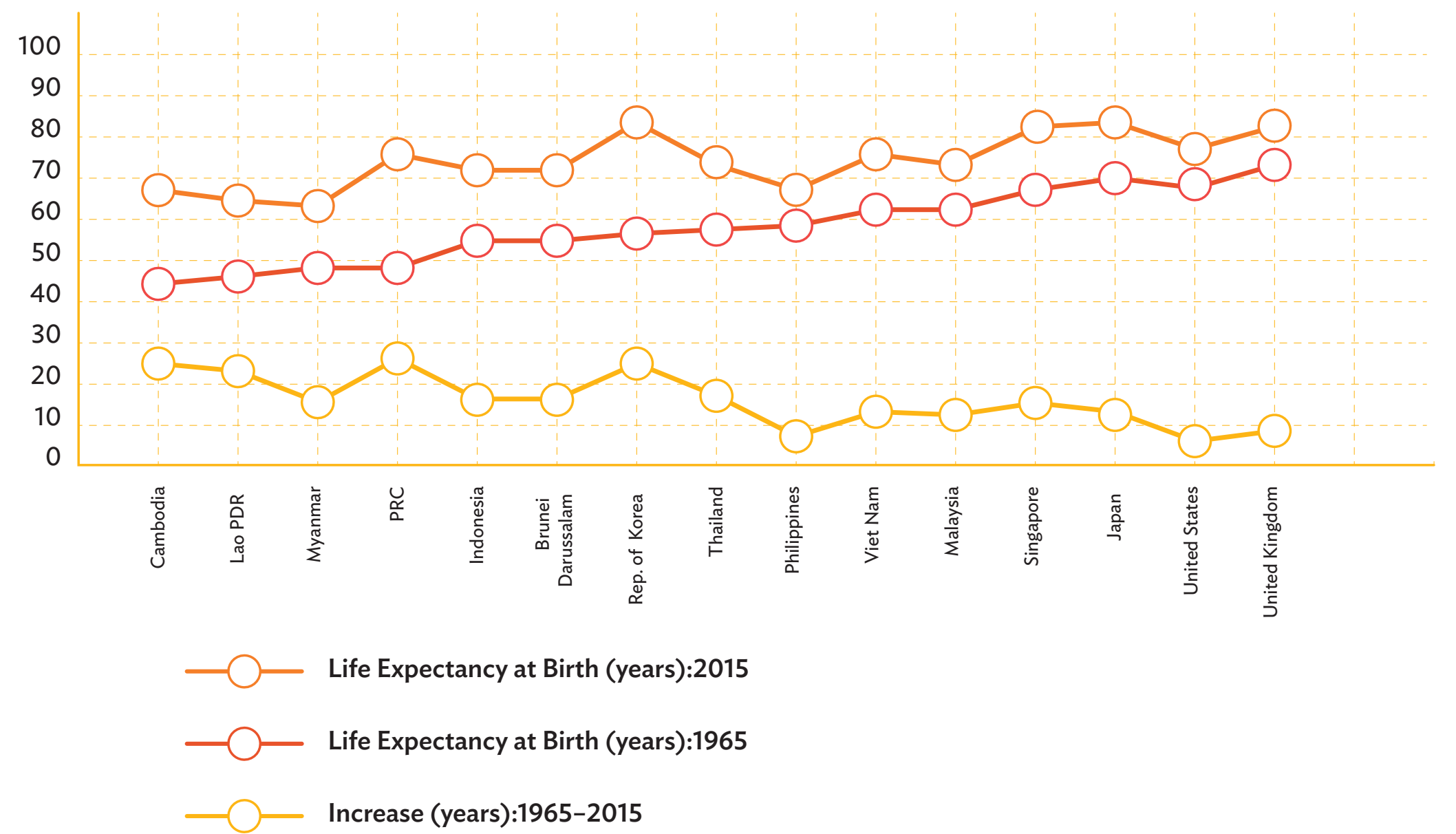

PRC = People's Republic of China, Lao PDR = Lao People's Democratic Republic. (

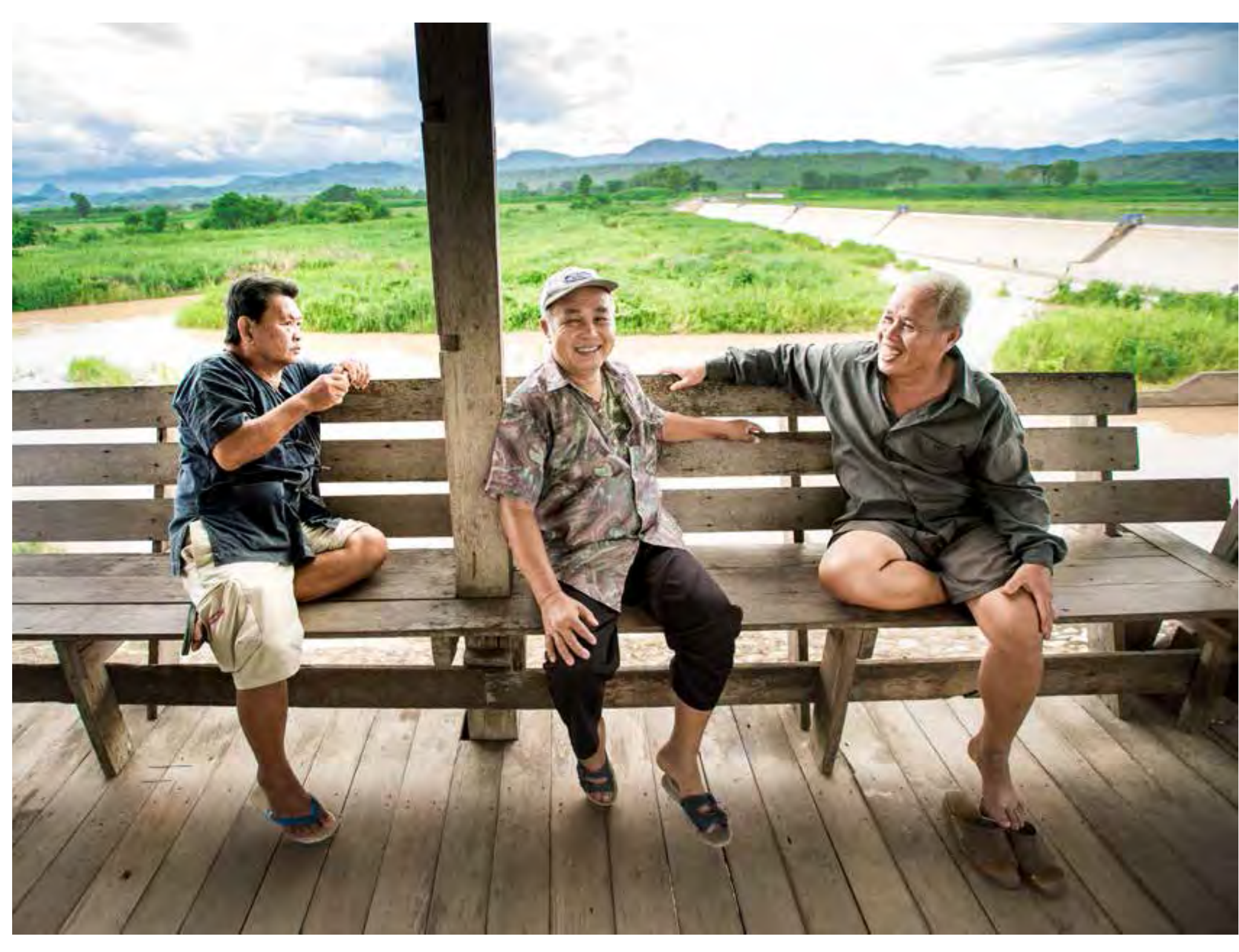


The picture has changed dramatically in the ensuing 50 years. Several countries, including Thailand, have made the transition to middle-income status, and others are now among the most prosperous nations in the world. The Republic of Korea's gros domestic product per capita has increased 259-fold since 1965 while both the PRC and Singapore have also seen huge per capita economic gains. Economic growth has been mirrored by welfare ence by significant improvements in life expectancy in most of the region's countries.

DB designated functions were (a) to attract additional development funds to the region; (b) to finance projects and facilities for the economic and social development of the region, which were not then adequately financed through existing agencies; and (c) to act as a focal point for and stimulus to other measures for regional economic cooperation.

\section{EARLY HISTORY OF THE ASIAN} DEVELOPMENT BANK

International financial institutions (IFIs) have their origins in the mmediate post-World War II period, and were initially establishe to help rebuild the war-damaged economies of Europe, and to bring rules-based stability and cooperation to the international financial system. From 1960, lower-cost financial assistan was also provided to aid the development of poorer countries through the International Development Association, which now, ogether with the International Bank for Reconstruction and Development (IBRD), constitutes the World Bank. However, the World Bank and other agencies were unable to meet the urgent development assistance needs of the smaller countries of Asia, other than India and Pakistan. This partly provided the rationale for the establishment of a development bank specifically for Asia, which, in addition, could be especially sensitive to Asian contextual environments and particular development needs and terests. The idea of a multilateral development bank for $A$ sia was first presented at the Simla Conference (India), held under the auspices of the Colombo Plan in 1955. But it was not until 963 that the idea of a regional development bank for Asia was discussed formally. The initial impetus came from the United ations Economic Commission for Asia and the Far East, which was eyeing a package of initiatives intended to accelerate region cooperation
An expert panel was convened after the 19th Session of the United Nations Economic Commission for Asia and the Far East in early 1963 to report to the Ministerial Conference in Manila later that year. The expert panel met in Bangkok in August and September 1963, and one of their recommendations was the establishment of
a regional bank "to assist in mobilizing and directing resources for a regional bank "to assist in mobilizing and directing resources for gronal projects, joint ventures and for trade" (White, 1970, 42). Another expert group, this time including Takeshi Watanabe, a Japanese banker and prominent financial consultant and who would later become ADB's first President, was tasked with developing a framework for the propose regional development bank. Its designated functions were (a) to attract additional development funds to the region; (b) finance projects and facilities for the economic and social developmen of the region, which were not then adequately financed through existing agencies; and if possible (c) to act as a focal point for and stimulus to other measures for regional economic cooperation (White, 1970, 42).

While the framework for a regional development bank was agreed in principle, a number of sticking points needed to be overcome before ADB could become a reality. The first concerned the initial capitalization of ADB, with Japan, at the time Asia's only developed country, reluctant to take full financial responsibility, arguing that it was desirable to involve other developed countries from outside the region in order not to limit ADB's capacity to mobilize funds for development (Watanabe, 1977, 2). In April 1965, faced with the United States' worsening position in Viet Nam, President B. Johnson announced a special development fund for e Mekong River region which, he claimed, would help stimulate the development of Southeast Asia more generally. Former World Bank President Eugene Black was appointed by Presiden Johnson as his special advisor on Southeast Asia. Mr. Black attended the Consultative Committee meeting in Bangkok, and shortly afterwards, on 28 June 1965, announced that the United States was willing to subscribe up to $20 \%$ of ADB's proposed nitial capital of $\$ 1$ billion (Watanabe, 1977, 8). The Government Japan had already expressed a willingness to contribute a dentical sum. Along with other non-Asian developed countries and an array of Asian developing countries, ADB managed to reach is target of $\$ 1$ in voting rights and the balance of control between regional and nonregional members, the location of the headquarters, the choice of President, and the design of the management structure, ADB held its inaugural meeting in Tokyo on 24 November 1966. 
ADB's first loan to Thailand, and indeed its very first loan

disbursement, was to the Industrial Finance Corporation of

Thailand, which had been created in 1959 by the government (but

operated as a private organization) to provide medium- and long-

term loans to industrial enterprises. The country's commercial

banks provided only short-term finance which, while useful for

capital needed for the establishment of new enterprises and the

expansion of existing businesses, which was the cornerstone of

the government's industrialization policy. 


\section{Table 2: ADB Loans to the Industrial Finance Corporation of Thailand, 1968-1983}

\begin{tabular}{|c|c|c|c|}
\hline Loan No. & Project & Amount (\$ million) & Approval Date \\
\hline 1 & IFCT I & 5 & Jan 1968 \\
\hline 24 & IFCT II & 10 & Dec 1969 \\
\hline 226 & IFCT III & 20 & Aug 1975 \\
\hline 358 & IFCT IV & 30 & Sep 1978 \\
\hline 543 & IFCTV & 50 & Nov 1981 \\
\hline 663 & IFCT VI & 25 & Dec 1983 \\
\hline
\end{tabular}

In total, the Asian Development Bank (ADB) contributed \$140 focused on labor-intensive agro-processing, but from the early million to the Industrial Finance Corporation of Thailand (IFCT) 1970s they were increasingly used to support the government's across six project phases and in almost 2 decades. Loans generally import-substitution industrialization policy and, in the early had a 15-year amortization period, and were used by the IFCT to 1980s, Thailand's expanding export-oriented industrialization nt and ADB policy emphasized the need make subloans to domestic industrial firms operaing in diferent strese parts of the country and across an array of manufacturing to support industrialization away from Greater Bangkok, with a subsectors. The size of subloans to domestic firms was subject to minimum of $40 \%$ of subloan projects to be located elsewhere in a maximum threshold to ensure that healthy numbers of small and the Central Region, and in the peripheral regions. Overall, ADB's medium-sized enterprises were able to benefit from the finance financial intermediation in Thailand, through the credit provided available. ADB loans were in US dollars, and were intended to to the IFCT from 1968-1983, grealty contributed to Thailand's augment the IFCT's foreign exchange resources which, in turn, were industrial development and transformation, generating thousands required by industrial firms to make transactions on international of new jobs and boosting export earnings, and helping to lay the markets. In line with government policy and the character of the foundation for the economic boom which occurred through the industrial sector at the time, ADB-funded subloans were initially 1980 s and early 1990 s.

Source: Asian Development Bank.
Electricity Generation and Distribution

A second crucial priority area for the development of the Thai economy was the generation and distribution of the electricity power that was needed both to support industrialization and to improve the welfare of urban and rural populations alike. The energy sector has long been (and continues to be) a major focus of ADB lending to Thailand. Between 1970 and 1996, ADB made the biggest external assistance contribution to Thailand's power sector of all the bilateral and multilateral international development agencies, lending a total of $\$ 1.4$ billion.

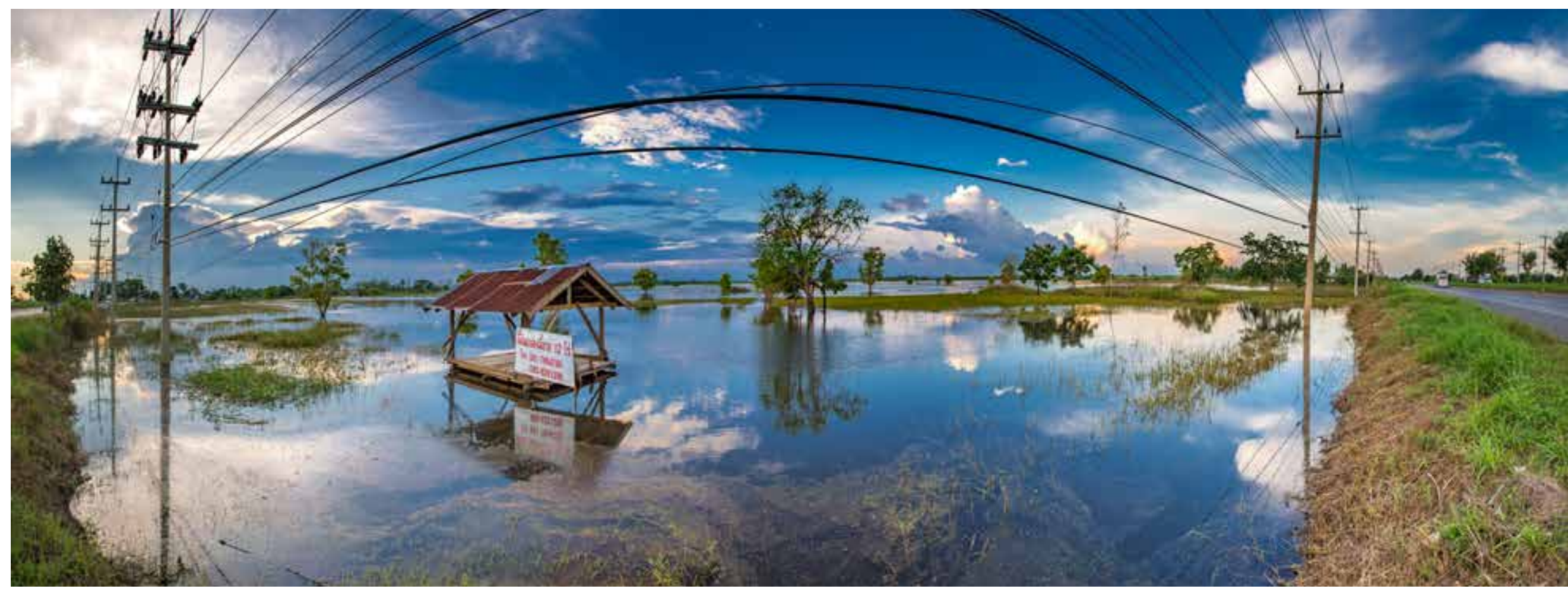




\begin{tabular}{|c|c|c|c|}
\hline Loan No. & Project Name & Amount (\$ million) & Approval Date \\
\hline \multicolumn{4}{|c|}{ Electricity Generating Authority of Thailand (EGAT) } \\
\hline 50 & Power Transmission \& Substation Expansion Project & 19.00 & Dec 1970 \\
\hline 113 & Mae Moh Power Project & 23.00 & Dec 1972 \\
\hline 191 & Second Power Project & 24.00 & Aug 1974 \\
\hline 219 & Mae Moh Power (Supplementary) & 15.00 & Apr 1975 \\
\hline 220 & Second Mae Moh Power Project & 22.70 & Apr 1975 \\
\hline 304 & Third Power Project & 47.00 & Aug 1977 \\
\hline 360 & Fourth Power Transmission Project & 36.50 & Oct 1978 \\
\hline 440 & Mae Moh (Unit 4) Power Project & 81.80 & Dec 1979 \\
\hline 502 & Power System Expansion Project & 85.00 & Dec 1984 \\
\hline 613 & Second Power Expansion Project & 81.60 & Dec 1982 \\
\hline 717 & Mae Moh (Unit 8) Power Project & 122.60 & Dec 1982 \\
\hline 828 & Mae Moh (Unit 9) Power Project & 38.40 & Dec 1986 \\
\hline 1022 & Transmission System for Mae Moh & 48.80 & Jun 1990 \\
\hline 1170 & Third Power Transmission (Sector) & 94.25 & Jul 1992 \\
\hline \multirow[t]{2}{*}{1245} & Fourth Power Transmission (Sector) & 115.60 & Aug 1993 \\
\hline & Total loans for EGAT Projects & 855.25 & \\
\hline
\end{tabular}

\begin{tabular}{|c|c|c|c|}
\hline Loan No. & Project Name & Amount ( $\$$ million) & Approval Date \\
\hline \multicolumn{4}{|c|}{ Metropolitan Electricity Authority (MEA) } \\
\hline 80 & Power Distribution Project & 18.00 & Dec 1971 \\
\hline 153 & Second Power Distribution Project & 21.00 & Nov 1973 \\
\hline 265 & Third Power Distribution Project & 37.00 & May 1976 \\
\hline 359 & Fourth MEA Power Distribution Project & 33.70 & Sep 1978 \\
\hline 535 & Fifth MEA Power Distribution Project & 61.00 & Oct 1981 \\
\hline 903 & Sixth Power Distribution (Sector) Project & 64.75 & Sep 1988 \\
\hline 1151 & Seventh Power Distribution (Sector) Project & 109.00 & Jan 1992 \\
\hline \multirow[t]{2}{*}{1246} & Eighth Power Distribution (Sector) Project & 134.60 & Aug 1993 \\
\hline & Total Loans for MEA Projects & 479.05 & \\
\hline \multicolumn{4}{|c|}{ Provincial Electricity Authority } \\
\hline \multirow[t]{2}{*}{1429} & Rural Electrification Project & 100.00 & Jan 1996 \\
\hline & Total Loans for the Power Sector & $1,434.30$ & \\
\hline
\end{tabular}


Around the mid-1980s, the environmental impact of power generation particularly thermal power became a growing concer Accordingly, ADB started commissioning environmental impact studies, producing mitigation plans, and systematically monitoring environmental emissions from projects that it supported. In Bangkok, as part of its support to the Metropolitan Electricity Authority, more power cables were installed underground to help minimize environmental and aesthetic impacts, including the first submarine cable under the Chao Phraya River.

Transport Infrastructure

Another form of infrastructure development, which has proven essential to both economic and social progress in Thailand, is transport. ADB has made a major contribution with almost $\$$ billion between 1974 and 1995 in this sector.

Foremost in ADB's involvement in the transport sector has been its contribution to the country's highways system. In conjunction with the Department of Highways (DOH), Ministry of Transport the three ADB highway projects of the late 1970s played a catalytic role in the development of the Eastern Seaboard, which helped ease some of the mounting economic and social pressures in Bangkok by allowing industrial, residential, and recreationa activities to spread out toward the east along the arterial routes between Bang Na, Bang Pakong, Chonburi, and Si Racha and

The three ADB highway projects of the late 1970s played a catalytic role in the development of the Eastern Seaboard, which helped ease some of the mounting economic and social pressures in Bangkok by allowing industrial residential, and recreationa activities to spread out toward the east along the arterial routes between Bang $\mathrm{Na}$, Bang Pakong, Chonburi, and Si Racha and Pattaya.

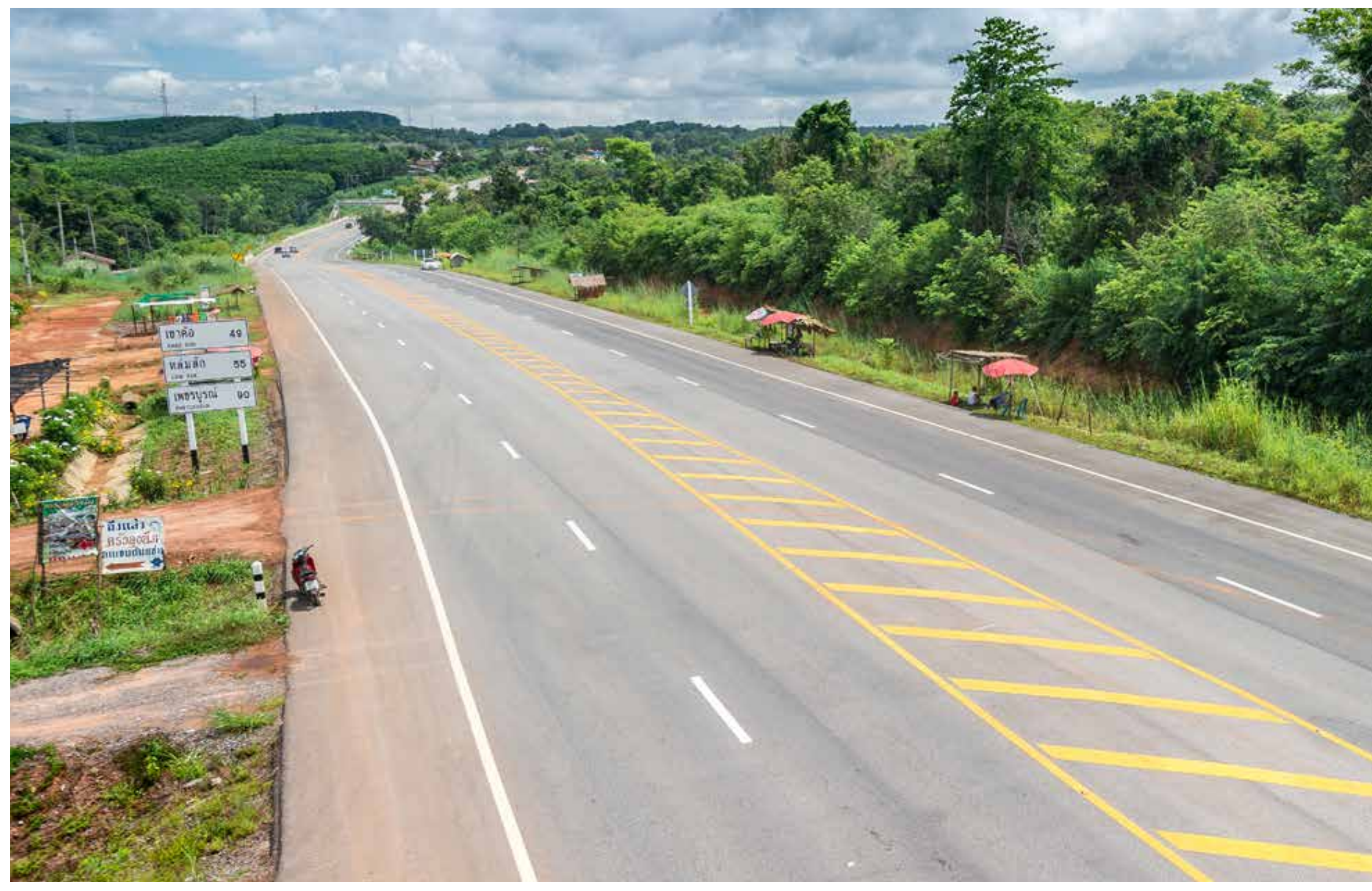




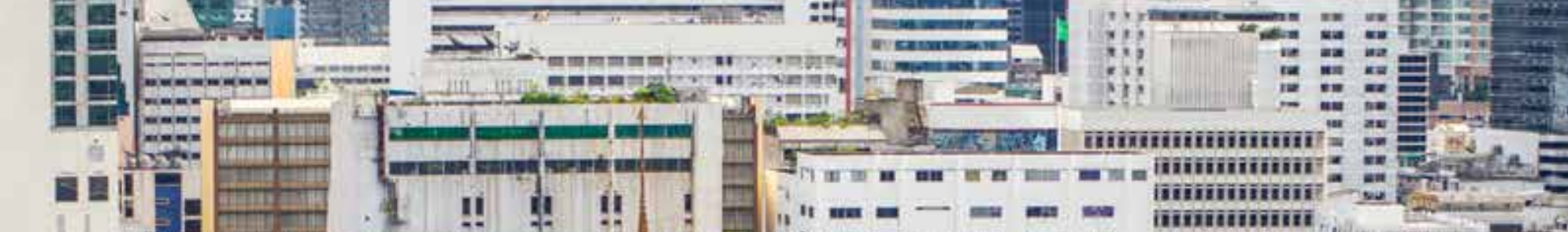

$\begin{array}{lccc} & & \text { (\$ million) } & \\ 0178 & \text { Highway Project } & 12.60 & \text { Jan } 1974 \\ 0259 & \text { Second Highway Project } & 11.06 & \text { Mar 1976 } \\ 0355 & \text { Songkhla and Phuket Ports Project } & 0.22 & \text { Sep 1978 } \\ 0383 & \text { Third Highway Project } & 35.33 & \text { Dec 1978 } \\ 0503 & \text { Highway (Sector) Project } & 56.51 & \text { Dec 1980 } \\ 0546 & \text { Songkhla and Phuket Ports Project } & 47.28 & \text { Nov 1981 } \\ 0943 & \text { Second Highway (Sector) Project } & 105.02 & \text { Jan 1989 } \\ 1027 & \text { Third Highway (Sector) Project } & 33.69 & \text { Aug 1990 } \\ 1098 & \text { Fourth Highway (Sector) Project } & 60.00 & \text { Sep 1991 } \\ 1179 & \text { Fifth Highway (Sector) Project } & 93.00 & \text { Aug 1992 } \\ 1195 & \text { Bangkok Urban Transport Project } & 70.30 & \text { Nov 1992 } \\ 1306 & \text { Regional Roads (Sector) Project } & 170.00 & \text { Jul 1994 } \\ 1391 & \text { Second Regional Roads (Sector) Project } & 180.00 & \text { Sep 1995 } \\ & \text { Total } & 875.01 & \\ \end{array}$

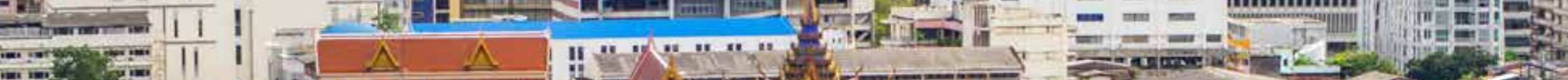

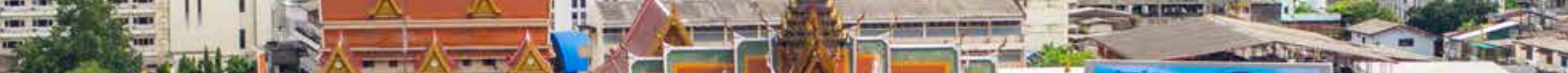

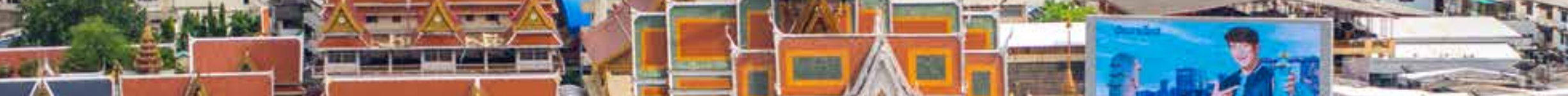

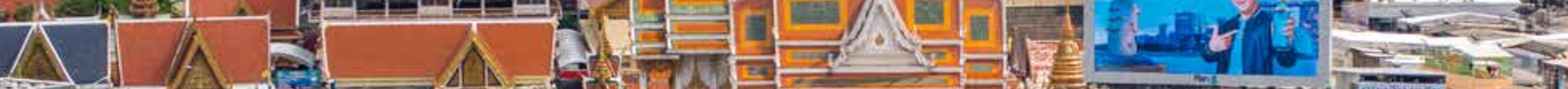

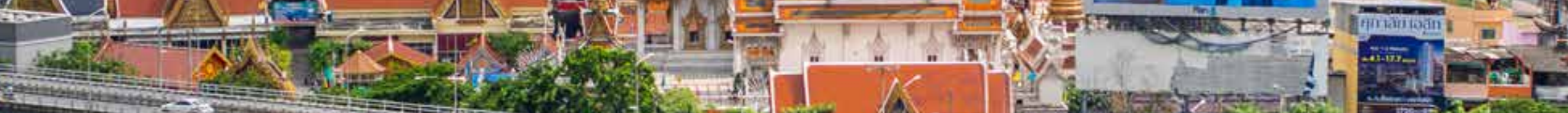

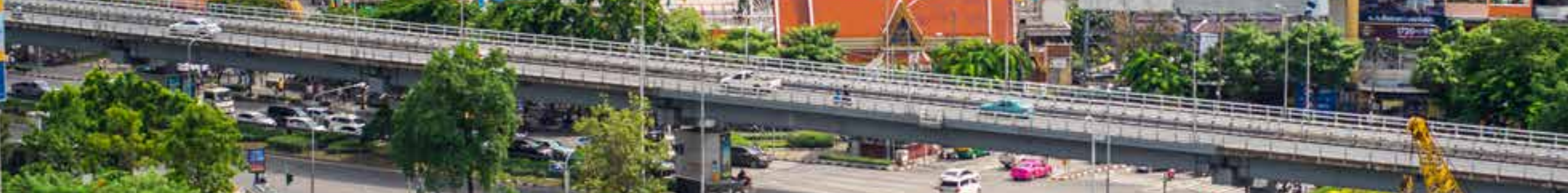

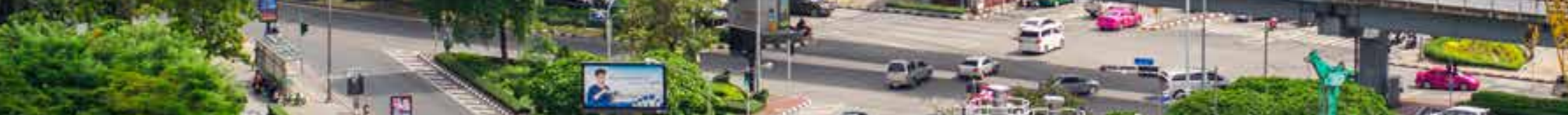

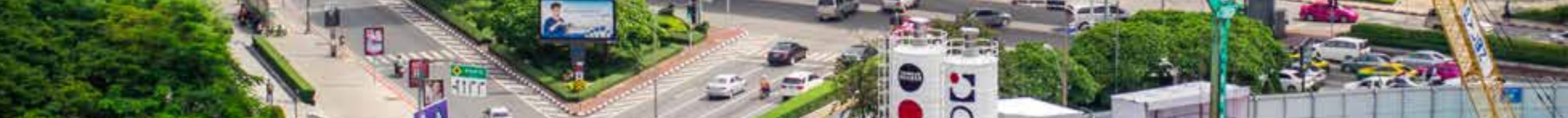

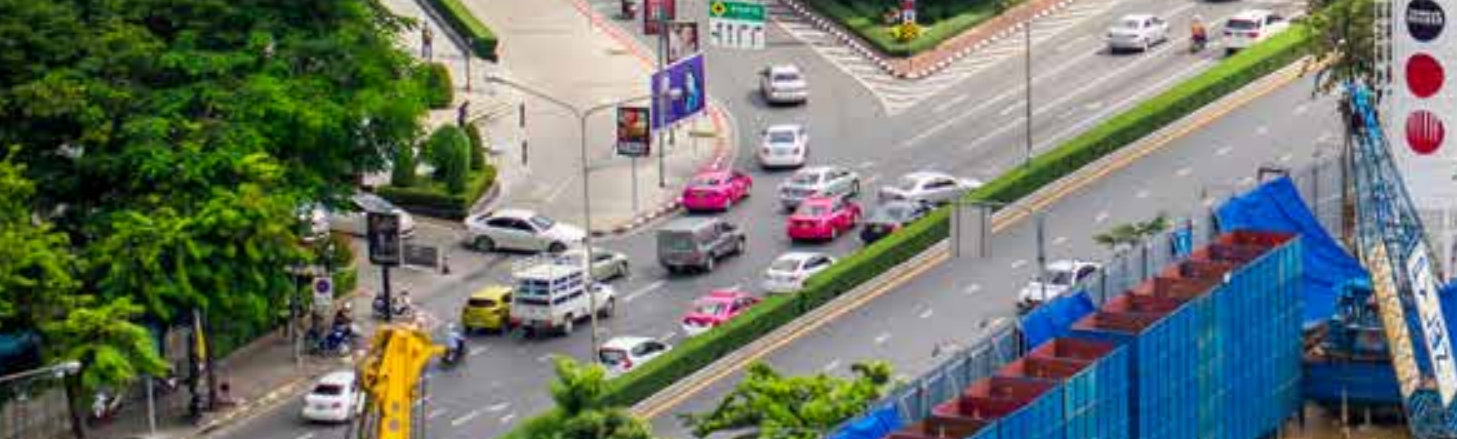

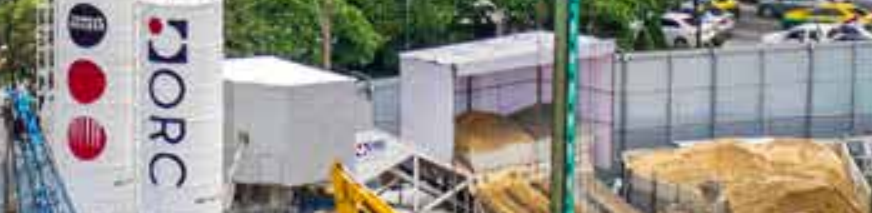

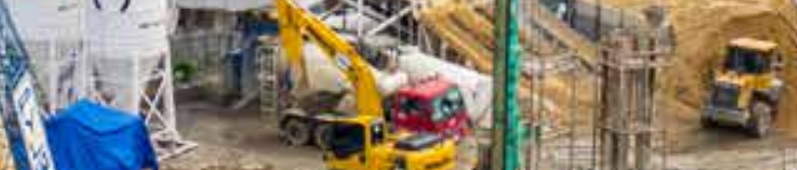

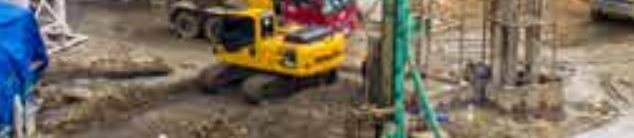


In the 1980s, ADB switched from a project-based model for supporting highways development to a sector-based approach whereby ADB would provide loan funding to the DOH, which, in turn, would select and appraise subprojects in accordance with criteria that had been agreed with $A D B$ as principal lender. In in 1980 with the last in 1992, contributing more than \$350 millio mostly to cover the foreign exchange costs of civil works, to the construction and improvement of the provincial highway network throughout Thailand's four geographical regions, in line with the objectives of the fifth and sixth national plans.

During the seventh plan period, ADB funded a Bangkok Urban Transport Project, which focused in the main on building missing link in the capital city's primary road network-the Tho Buri road extension from Taksin Bridge to Phetkasem Road. The project helped to ease a significant bottleneck in Bangkok's road system, improve efficiency of the road system and provide a direct benefit to the poor by time savings in bus journeys. The construction of the new road required the resettlement of some 1,221 households, which brought some challenges to the executing agency, the Department of Public Works. In 1995, AD introduced a Resettlement Policy, which established essential displaced persons. the provision for institutional support for transport planning, policy formulation, and assessment through the Office of the total, $A D B$ funded five highway sector support programs, starting

Water management was another important area of ADB-funded development assistance, amounting to more than $\$ 350$ million between 1973-1997. In parallel to ADB investment in road infrastructure in the Eastern Seaboard development region, water supply was also a crucial contributor to economic development environmental improvement, and social welfare enhancement. The Chonburi Water Supply Project was one of three sets of projects that focused on the water sector in Bangkok and the Eastern Seaboard. Because of the rapid economic growth and population expansion in Chonburi during the 1980s and 1990 there were chronic deficiencies in water supply to industria agricultural, residential, and commercial users in the province. Supplies were inte ity was poor, with many vendors. The project sought to improve water supply for 222,000 people an businesses (although it actually reached more than 300,000 in the end) through the rehabilitation and expansion of water treatmen plants, storage reservoirs, pumping stations, transmission and distribution systems; reduction in water leaks; and supply of consumer meters. The project helped improve public health and environmental conditions, and made an impact on urba poverty by providing affordable piped water to the poor, includin waterfront areas which were home to poorer fishing communities.

23 ADB and Thailand-A Development Partnership toward Inclusive Growth
Significant investment was also targeted at the capital city's water supply system through three project loans. The four rapidly growing municipalities, which make up metropolitan Bangkok were, like Chonburi, unable to meet runaway demand. At the time of the first Bangkok Water Supply Project in 1973, nearly $40 \%$ of the city's population, mostly the lowest-income groups, had no formal water supply at all, and less than a quarter had a continuous supply at adequate pressure. Thirty percent of Bangkok's water supply was drawn from groundwater sources, which was contributing to subsidence and the gradual sinking of the capital city. Working with the Metropolitan Waterworks Authority (MWA), ADB doubled the water supply and distribution capacity, serving an additional 2.5 million people, as well as improving the service of the $M$ and water pollution had become a serious health hazard and aesthetic nuisance. ADB support focused on the development of centralized wastewater treatment facilities, consisting of the construction of more than $300 \mathrm{~km}$ of interception and collection sewers, 60,000 property connections, and treatment plants, aeration lagoons, and various monitoring systems. There was also a component for strengthening the institutional capacity for planning and implementing wastewater management projects. The project helped significantly to improve the quality of the living environment in the lower reaches of the Chao Phrya River

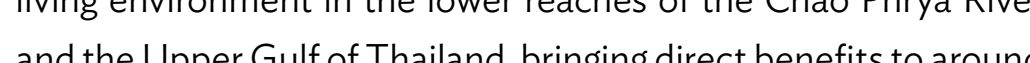
1 million residents, businesses, and institutions in the area. 
Table 5: ADB Support for Water Supply and Wastewater Management in Thailand, 1993-1997

\begin{tabular}{|cccc|}
\hline Loan No. & Project Name & $\begin{array}{c}\text { Amount } \\
(\$ \text { million })\end{array}$ & Approval Date \\
\hline 0137 & Bangkok Water Supply Project & 16.92 & Jul 1973 \\
0443 & Second Bangkok Water Supply Project & 63.96 & Dec 1979 \\
0735 & Third Bangkok Water Supply Project & 45.84 & Mar 1985 \\
1326 & Chonburi Water Supply Project & 38.50 & Oct 1994 \\
1410 & Samut Prakarn Wastewater Management Project & 150.00 & Dec 1995 \\
1528 & Nong Khai-Udon Thani Water Supply Project & 50.00 & Aug 1997 \\
& Total & 365.22 & \\
&
\end{tabular}

Source: Asian Development Bank.

Agriculture and Fisheries

While a great deal of financial support was understandably directed at the infrastructure requirements of Thailand's economic boom and associated urgent social development needs during the 1970s and 1980s, in lne with the Governent of Thailand's focus in the fist four natonal developmen on fostering economic growth, the primary farming and fishing sectors were not neglected. More than $\$ 600$ million was invested in these sectors from 1974 until the onset of the financial crisis in 1997.
The first project was directed at Thailand's marine fishery. The underlying objective was to improve the incomes of poore fishers while, at the sa contribute to the domestic maket The Fisheries Develophto Project was the first exteral assistance to the Tha fishent Procet was the fist external assistance to the Thai fisheries sector, and fisheries development had been afforded a high priority in the third national development plan. ADB provided financial resources to the Fish Marketing Organization, which then made financingavala then made fnancing available to fissers to enable then to upgrade their boats, engines, navigation equipment, and fishing gear. Some 
$3 \%$ of the entire fleet of 4,500 vessels was modernized under this ram. The project also improved fish marketing, cold storage, and distribution systems.

Another strategy for raising fish production and exports, easing exploitation pressure on marine fishery, centered on the expansion and modernization of fish- and prawn-farming. The Aquaculture Development Project sought to introduce scientific methods to fry hatcheries and fish pond culture, upgrading existing ponds and, in southern Thailand, and introducing brackishwater pond estate settlements where support facilities could be shared and developed in producer cooperatives. ADB funding for the upgrading of existing ponds and the construction of new fish farms was disbursed via credit provided by the Bank for Agriculture and Agricultural Cooperatives (BAAC). The Brackishwater Shrimp Culture Development Project took a similar methodology to southern Thailand. By the time this project was inpley to sout in the mid-1980s, the aquaculure boom in Tha ind was aleady wellunder way. The prncipa focus of the Brackishwater Shrimp Culture Development Project was to help increase export earnings from cultured fish and prawn production, and to reverse some of the negative environmental consequences of earlier aquaculture expansion.

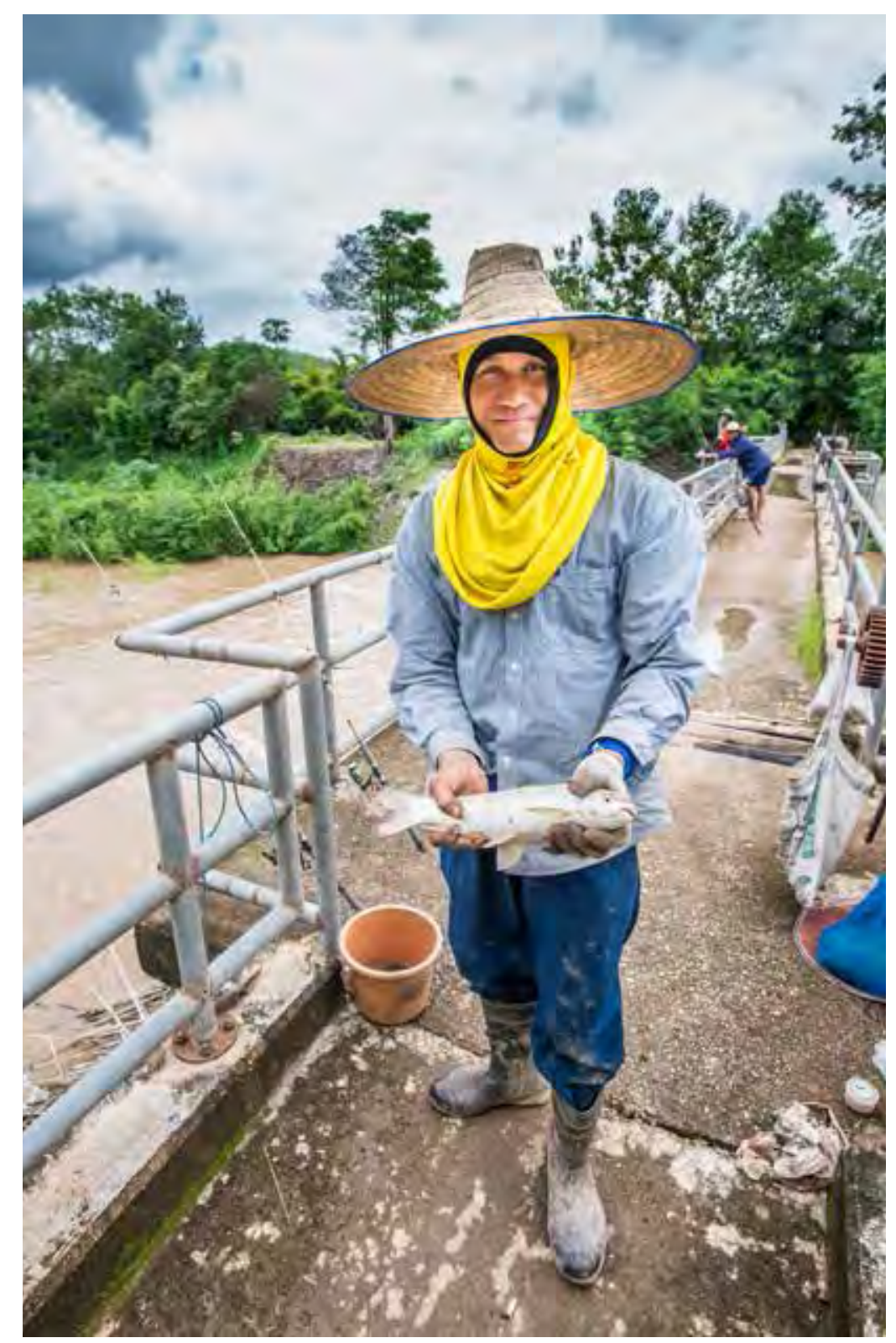

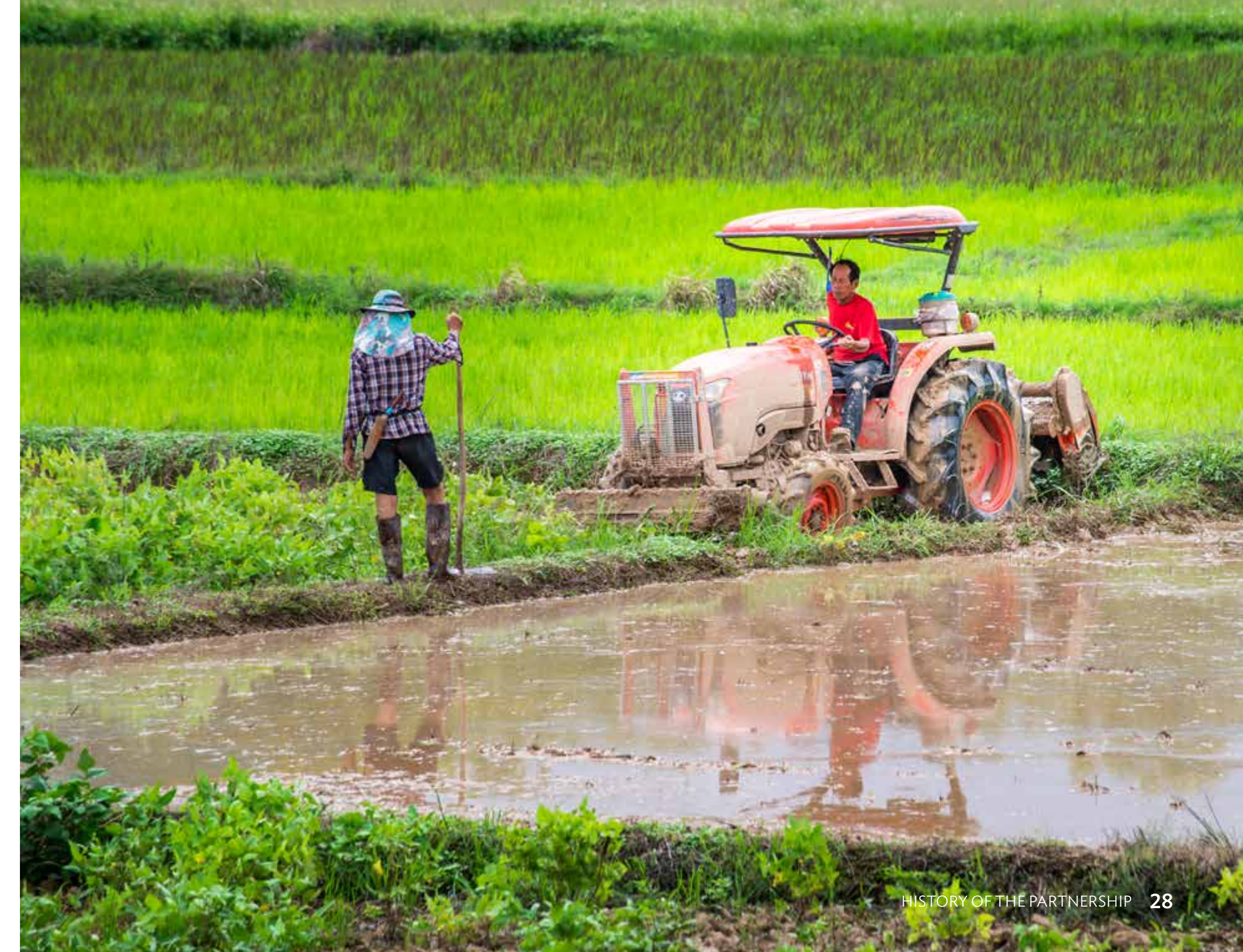

G. 
Table 6: ADB Support for the Agriculture and Fisheries Sectors, 1974-1999

Loan No.

\section{6}

0248

0264

0365

0367

0556

0557

0664

0787

1423

1540

1698
Project Name

Nong Wai Pioneer Agriculture Project

Fisheries Development Project

Southern Land Settlements Project

Kud Multipurpose Project

Aquaculture Development Project

Medium-Scale Irrigation Package Project

Medium-Scale Irrigation Package Project

Agricultural Credit Project

Brackishwater Shrimp Culture Development Project

Small Farmer Credit Project

Rural Enterprise Credit Project (post-crisis)

Agricultural Sector Program (post-crisis)
Source: Asian Development Bank.

Amount
(\$ million)

Approval Date

4.98

Dec 1974

$$
9.80
$$

Dec 1975

May 1976

Nov 1978

Nov 1978

Dec 1981

Dec 1981

Dec 1983

Sep 1986

Jan 1996

Sep 1997

Jan 1999

$$
\text { Total }
$$

300.00

639.28
A final important $A D B$ contribution to the agriculture sector came in the form of a series of agricultural credit projects aimed at supporting intensification and diversification, and the development of off-farm rural enterprises. The Agricultura Credit Project was introduced in 1983 to help farmers to mechanize their farms; improve farm production practices; and diversify into new crops, products, and activities by means of short-, medium-, and long-term credit disbursed as subprojects by the BAAC. Mechanization was seen as a key to intensification, while farmers also needed to avail themselves of the new ricegrowing technologies and high-yielding varieties of other crops. The project consisted of a crop loan scheme, intended to benefit 175,000 borrowers, and an equipment loan scheme, which would allow farmers to purchase power tillers, tractors, water pumps, threshers, and small trucks. Overall, the Agricultural Credit Project benefited about 247,000 farmers.

The 1996 Small Farmer Credit Project was designed to provide support to farming households for the enhancement of off-farm and agriculture-related activities, such as the development of small and medium-sized enterprises (SMEs). ADB was the first international agency to develop a program specifically for this sector. The ration lo was longer-term competit the rural sector and in the process, helping to promote the regional dispersal of economic activity and balance the ruralurban distribution of incomes. In addition to providing funds farming households through BAAC, ADB's support also included enhancing the BAAC's institutional capacity to lend support to the rural off-farm sector. BAAC lending for agriculture-relate activities accounted for $5.4 \%$ of total disbursements in 2000, up from $2 \%$ in 1996. The Small Farmer Credit Project covered all of Thailand with the exception of the five provinces which make up Greater Bangkok. The Rural Enterprise Credit Project was an extension of the Small Farmer Credit Project, but was designed more specifically to help farmers diversify their rural enterprises as a direct response to the disruption caused by the 1997 financial crisis.

\section{Summary}

From the start of its involvement in economic and social development in Thailand in 1968 until the onset of the Asian financial crisis in 1997, ADB disbursed $\$ 3.5$ billion dollars in support of 73 infrastructural, rural, and regional development projects in conjunction with Thailand's evolving national economic and social development plans. Through almost 3 decades of assistance, both the development landscape and the definition of "development" underwent quite profound change, shifting from a narrow equating of development with economic growth to be achieved through infrastructure investment, to a broader more nuanced interpretation, which recognized and sought to ameliorate the distributional, social, and environmental shortcomings of a narrow growth-driven approach. As a development partner to projects in conjunction with Thailand's evolving national economic and social development plans. 
Government of Thailand, ADB adjusted its lending profile to suit shifting development priorities and acted as a catalyst for directional change, contributing knowledge and technical expertise to help facilitate institutional capacity-building and the introduction of international development principles and bestpractice. During the first 3 decades of development cooperation, and true to the original vision of ADB President Takeshi Watanabe of creating "a financial institution that is Asian in its basic character," networks and partnerships were formed between ADB expert staff and the Government of Thailand and, increasingly, private sector stakeholders, which were reinforced through repeat projects and sequential sectoral support. Nevertheless, the financial crisis which hit Thailand and many other parts of East and Southeast Asia in July 1997 threatened to unravel a great dea of the development progress that ADB and the Thai authorities had together worked so hard to achieve.

\section{THE 1997 FINANCIAL CRISIS}

The 1997 economic crisis was triggered by speculative attacks on the baht, which exposed a number of deep underlying weaknesses in the country's financial system. The Government of Thailand spent billions of dollars of its foreign reserves in a vain attempt to defend the value of the baht, and then on July 21997 unpegged and devalued the national currency, seeing it almost immediately ve. Banks and private companies, which offshore financial mark with very poor regulatory supervision or safeguards, suddenly found themselves exposed to debts, which they could no longer afford to pay with the national currency. Debt, insolvency, and bankruptcy became the order of the day in the finance sector, and the problems very quickly spread to the real economywith social consequences.
During the first 3 decades of development cooperation, and

true to the original vision of ADB President Takeshi Watanabe

of creating "a financial institution that is Asian in its basic

character," networks and partnerships were formed between

ADB expert staff and the Government of Thailand and private

sector stakeholders, which were reinforced through repeat

projects and sequential sectoral support.
IFls were quick to respond to requests for help in stabilizing their economies and recapitalizing their banks. The Pledging Meeting held in Tokyo in August 1997 came up with a \$17.2 billion support package for Thailand, made up of $\$ 4$ billion from the International Monetary Fund, $\$ 1.2$ billion from ADB, $\$ 1.5$ billion from the IBRD, and $\$ 10.5$ billion from bilateral creditors, with Japan ( $\$ 4$ billion) at the forefront. The IFIs each took responsibility for supporting

different elements of Thailand's recovery from economic crisis.

International Monetary Fund focused on macroeconomic policy and the restructuring of the banking sector. The IBRD concentrated on corporate debt restructuring and preparing framework to allow finance companies to reestablish a platform of stability. ADB directed its resources at capital market reform and helping to ease some of the many problems facing the social

Table 7: ADB Support to Thailand in Response to the 1997 Asian Financial Crisis

\begin{tabular}{|rccc|}
\hline Loan No. & Project Name & $\begin{array}{c}\text { Amount } \\
(\$ \text { million })\end{array}$ & Approval Date \\
\hline 1540 & Rural Enterprise Credit Project & 200.00 & Sep 1997 \\
1600 & Financial Markets Reform Program & 300.00 & Dec 1997 \\
1611 & Social Sector Program & 500.00 & Oct 1997 \\
1612 & Export Financing Facility & 50.00 & Mar 1998 \\
1699 & Higher Education Development Project & 59.32 & Sep 1999 \\
1968 & Agriculture Sector Program & 300.00 & Jan 1999 \\
1735 & Restructuring of Specialized Financial Institutions & 11.00 & May 2000 \\
& Total & $\mathbf{1 , 4 2 0 . 3 2}$ & \\
\hline
\end{tabular}


ADB's crisis-response lending to Thailand included a mix of measures to stimulate economic activity and enhance competitiveness, on the one hand, and the facilitation of institutional reform in the financial, agriculture, and social sectors on the other. The crisis also came at a time when ADB was itself undergoing a transformation from a project-financing institution to a more broad-based development institution concerned with the policy environment within which its investments are placed. ADB's activities in Thailand, therefore, needed to respond to the country's changing policy context, with the 1997 Constitution and the eighth national plan (1997-2001) both signalling a shift in the balance of power between state and civil society. ADB's Interim Country Operational Strategic Strategy for Thailand signalled the prioritization of support to the agriculture, social, and finance sectors as a cornerstone strategy to bring the highest level of immediate post-crisis relief to rural populations in particular, while also facilitating much-needed institutional reforms.' In addition, reflecting shifting priorities across the development community more generally, ADB also sought to incorporate measures for environmental and natural resource protection and rehabilitation, targeted poverty reduction, narrowing the gender gap in development, and enhancing good governance.

ADB. 1999. Interim Country Operational Strategic Strategy for Thailand. Manila 33 ADB and Thailand-A Develooment Partnership toward Inclusive Grow

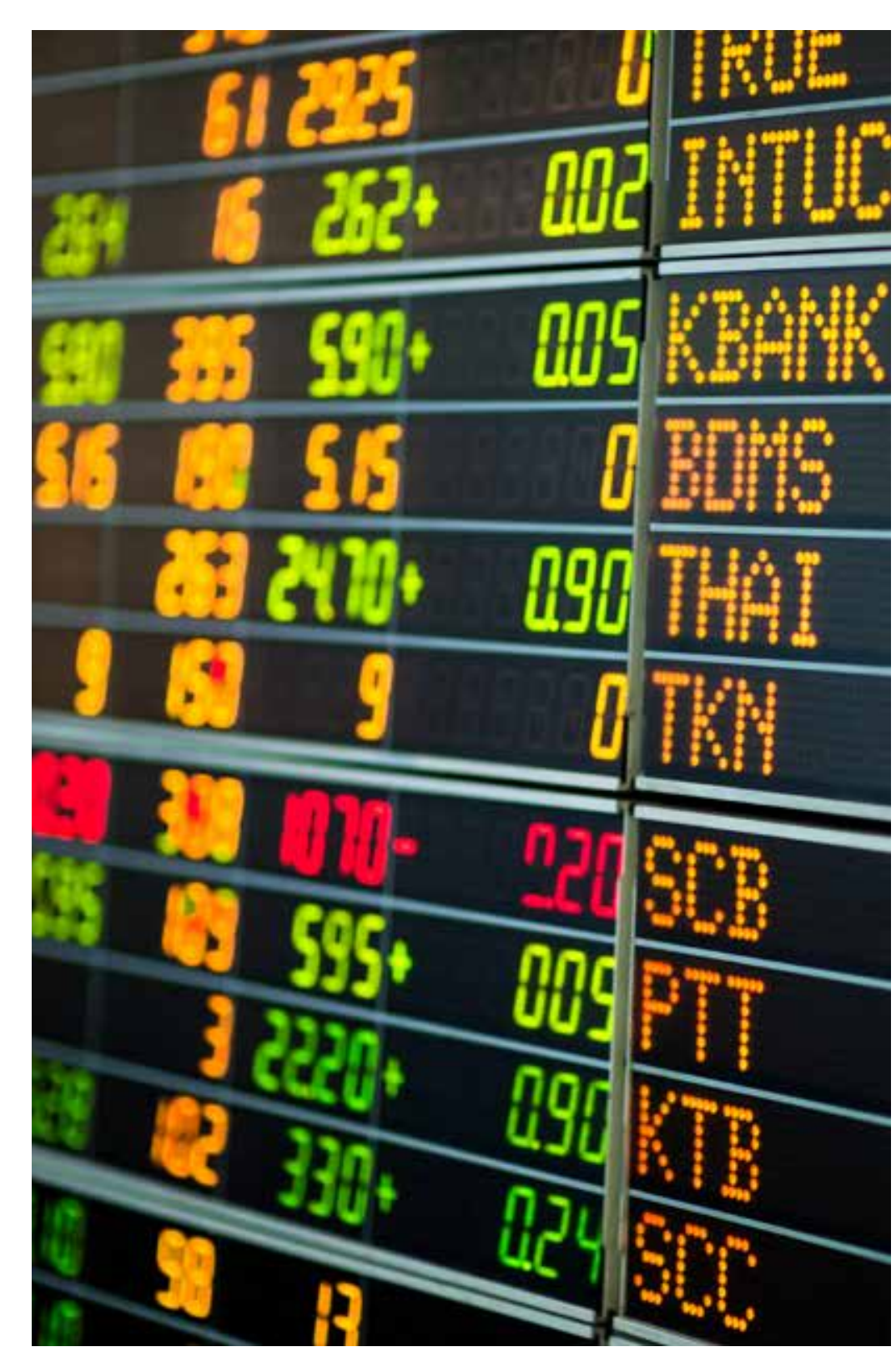

Box 1: The Rural Enterprise Credit Project

Credit Project would benefit 54,000 subborrowers to the une of about B250,000 per subloan, but in fact the number of beneficiaries reached 65,193 with an average subloan of just B85,270, as farmers sought to avail themselves of muchneeded short-term credit Overall, the Bank for Agriculture and Agricultural Cooperatives lending for farm-related projects increased to B13.7 billion in 1999, compared with B1.6 billion at the end of financial year 1995. Sixty-five percent of subloans were disbursed in the poorer north and northeast regions. the project predated the onset of the economic crisis, thus, the project did not demonstrate the crisis-specificity of other Asian Development Bank crisis-response programs. Nonetheless, its original earmarked budget of $\$ 100$ million was doubled to $\$ 200$ million in recognition of the severity of the economic and social pressures facing Thai farmers. The Rural Enterprise Credit Project was modeled upon the Smaller Farmer Credit Project, which had been implemented immediately before financial crisis. Building upon the relationship that had been cemented between the Asian Development Bank and the Bank for Agriculture and Agricultural Cooperatives as executing agency since 1983, the Rural Enterprise Credit Project sought to alleviate the sudden increase in rural poverty and unemployment, which in part was attributable to remigration (migrants returning to their rural homes from jobs in Bangkok and elsewhere) and made available for the creation or expansion of small-scale rural enterprises. It was initially anticipated that the Rural Enterprise

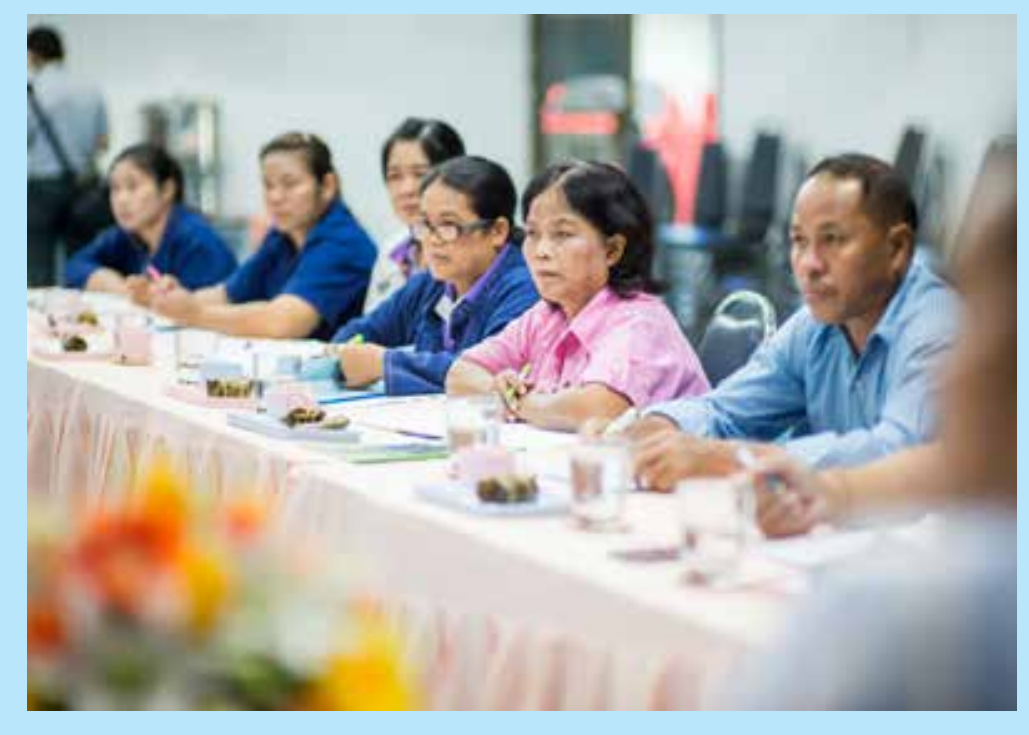




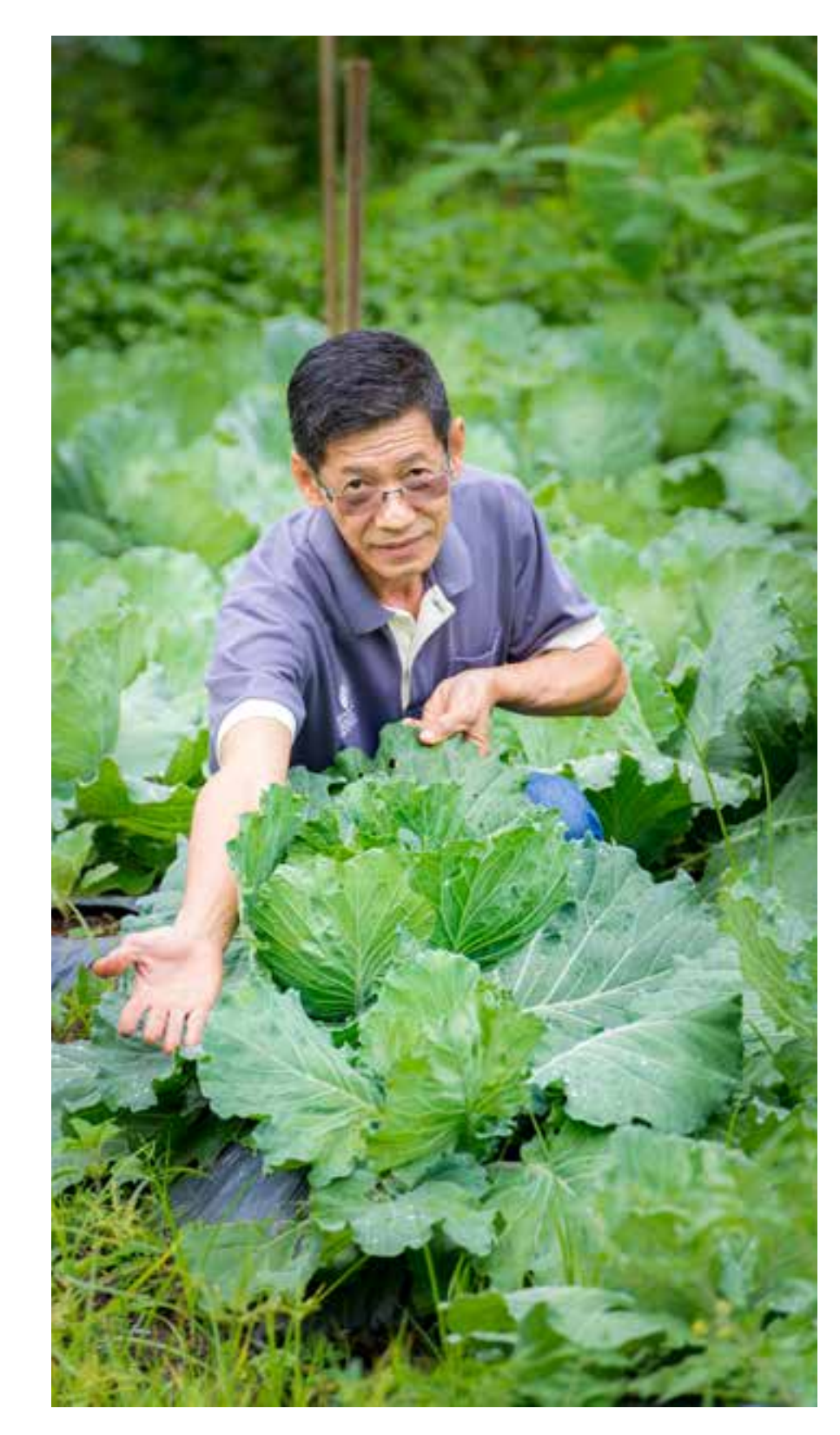

Thailand's rural sector came under particular pressure during the economic crisis as it served a safety net function for as many as 2 million migrant workers who returned to their home villages as they lost their city jobs. The countryside had to cope with the double whammy of supporting unemployed sons and daughters, while also losing the remittance income that, for a long time, had helped to sustain many rural households. The Agriculture Sector Program aimed to support Thailand's large rural sector, which accounted for $45 \%$ of the labor force and contributed $14 \%$ of total exports in the late 1990s. The sector deserved much attention because $13 \%$ of the aggregate population, classified as poor, were in this sector. It aimed to inject $\$ 300$ million contributed by the Asian Development Bank (and a further $\$ 300$ million from the Overseas Economic Cooperation Fund of Japan) into an array of agriculture- and natural resource-related projects and overdue institutional reforms. The program also reflected important changes in the priorities of Thailand's development planning which, although technically predating the onset of the crisis, nonetheless provided the philosophical platform that Thailand needed to help rebuild the economy, society, and physical environment as the country charted a path toward sustainable development in the post-crisis era. This objective would shortly be given greater urgency and centrality when the revered late King Bhumibol, reflecting on the lessons to be learned from the country's economic meltdown, put forward his New Theory of the Sufficiency Economy, which was to become the cornerstone of future national plans.
The Agriculture Sector Program emphasized both sustainability and reform. Raising agricultural productivity was a key focus but, for perhaps the first time in nationwide development planning the growth of the agriculture sector was to be conditioned by the careful management preservation, and rehabilitation of the natural resources based resource balancing productivity growth and ecological sustainability. Institutional reform centered on creating an integrated framework for water resource management, which tidied up overlapping, and sometimes competing, responsibilities of govent governance-providing political space for a much greater voice and input from local communities and nongovernme organizations. The program also sought to deal with inappropriate land use, and to confront the insecurity of land ownership, which many poorer people in particular faced. Source: Asian Development Bank.

Not only was the social impact of Thailand's economic crisis particularly severe for both rural and urban populations, th country's social protection system was also found wanting at a time when it was needed most. Thus, in addition to providing relief to the unemployed and some of the more vulnerable roups Thithe ADB's $\$ 500$ milon Social Sector Prog in Thailand, ADB's $\$ 500$ million Social Sector Program sought to initiate structural reforms to enhance economic competitiveness,
Coastal resource management was also to be given a high priority. Strengthening the export competitiveness of the agriculture sector was another core objective of the program, with a central role being given to improving agricultural research, and improving research-extension-farmer linkages. the main on the Cooperatives while enshrining rights for farmers, community organizations and nongovernment organizations to have more say in the direction of more decentralized agriculture sector planning Government efforts to engender institutional change provided by the Astin Develoument Bank under the to the Office of the National Water Resources Committee, the Royal Irrigation Department, the Royal Forest Department and the Department of Fisheries.

the efficiency of the social services. The loan was disbursed in two tranches, the first gave priority to short-term measures to alleviate the social impact of the crisis, while the second gave greater emphasis to structural reforms. Three technical assistance (TA) projects were also provided by $A D B$ on capacity building for social sector reforms, and on education and healh management, and financing. 


\section{Box 3: Social Sector Program}

There were 11 components to the impact mitigation measures, executed by four Thai ministries (Education, Public Health, Labour and Social Welfare, and Interior), which included scholarship funds for students affected by the crisis, trainin and labor force information especially for laid-off workers, support to disadvantaged urban preschool children, employment creation for community strengthening, financin health programs for the poor, and so on. Rather than specifyin precise expenditure allocations, the Asian Development Bank loan provided the Government of Thailand with flexibility in its use of funds according to its shifting priorities. Overall, Source: Asian Development Bank.

The aim of ADB's Financial Markets Reform Program was to address some of the major structural and regulatory shortcomings which contributed to the severity of the financial crisis. This was to be achieved by strengthening and decentralizing financial market regulation and supervision, improving risk management, developing alternative domestic means of raising finance for economic activity such as through an autonomous securities market, and improving the transparency and public accountability of market-based transactions. The Financial Markets Reform Program incorporated substantial provision for TA to provide government and private institutions with the knowledge required to push forward the reform agenda, particularly in the fields of pensions and provident funds, information disclosure and the program was considered successful in achieving its bjectives of protecting the poor and vulnerable, generating employment, and helping to limit poverty-induced school dropouts: more than 516,283 students were given scholarships to prevent crisis-induced school dropouts; 55,000 laid-off workers benefited from the extended social security coverage in 1998-1999; employment was created for more than 12,000 graduates; an additional 3 million people benefited from the public assistance health-care scheme for the poor; and 13,743 disadvantaged children were provided with food and milk across the country. The key indicators for education, health, and poverty whic course of 1998-1999, recovered quite strongly in 2000.

compliance, and asset securitization. An internal ADB evaluatio of the Financial Markets Reform Program observed that it achievements in facilitating capital market reforms had been remarkable, and went beyond the scope anticipated at the outset. An important contributory factor had been the strong ownership and implementation capacity of the country's Securities and Exchange Commission. Among the highlight achievements of the Financial Markets Reform Program was the promulgation of a Bankruptcy Act and the establishment of bankruptcy courts, the strengthening of the self-regulatory capacity of the Stock Exchange of Th the creation of a Public Debr Managenent Office (PDMO) coordinate government policies regarding government bonds; the listing and disclosure of performance information of SMEs on the SET (SME Exchange); the passing of a Corporatization Law which allows the conversion of state enterprises to limited companies within the framework of the government's Privatization Master Plan; and the introduction of a Derivatives Market Bill, which opened the way to the further development of capital markets Thailand.

Before the onset of the financial crisis, the Thai economy had been booming due in no small measure to the success of the country's export-oriented industrialization strategy. Fearful that export producers would be constrained by the contraction of commercia credit availability at just a time when Thailand needed to export its way out of the crisis, an Export Financing Facility was agreed between the Minister of Finance and ADB in September 1997. ADB agreed to provide a loan of $\$ 50$ million to the Export-Import

An internal $A D B$ evaluation of the Financia Markets Reform Program observed that its achievements in facilitating capital market reforms had been remarkable, and went beyond the scope anticipated at the outset. An important contributory factor had been the stron ownership and implementation capacity of the country's Securities and Exchange Commission.
Bank of Thailand; and, together with an international syndicate of commercial banks, a partial credit guarantee of $\$ 950$ million to underwrite confidence in the export sector.

\section{SUMMARY}

While providing loans in support of Thailand's development has been the core business of ADB since its inception in 1966, the TAs that $A D B$ has provided, both as an integral component of the loan projects and independently of them, were crucial to the success of various loan projects and programs, as well as to building capacity within the government institutions. Between 1969-2005, ADB funded 84 loans and 150 TAs including studies, appraisals, and training programs at a total cost of approximately $\$ 5.4$ billion and $\$ 55$ million, respectively. The ADB funded projects to Government of Thailand's ministries, departments, and stateowned enterprises, the added value from which has extended wel beyond the life cycle of individual projects.

The logistical demands of coping with the financial crisis, the shifting political environment with regard to internationa toward atraning the status of a midde-incon income country (MIC) had a significant effect on ADB's role in Thailand. These and other factors also contributed to the establishment of ADB's Thailand Resident Mission (TRM), as the following section will show. 


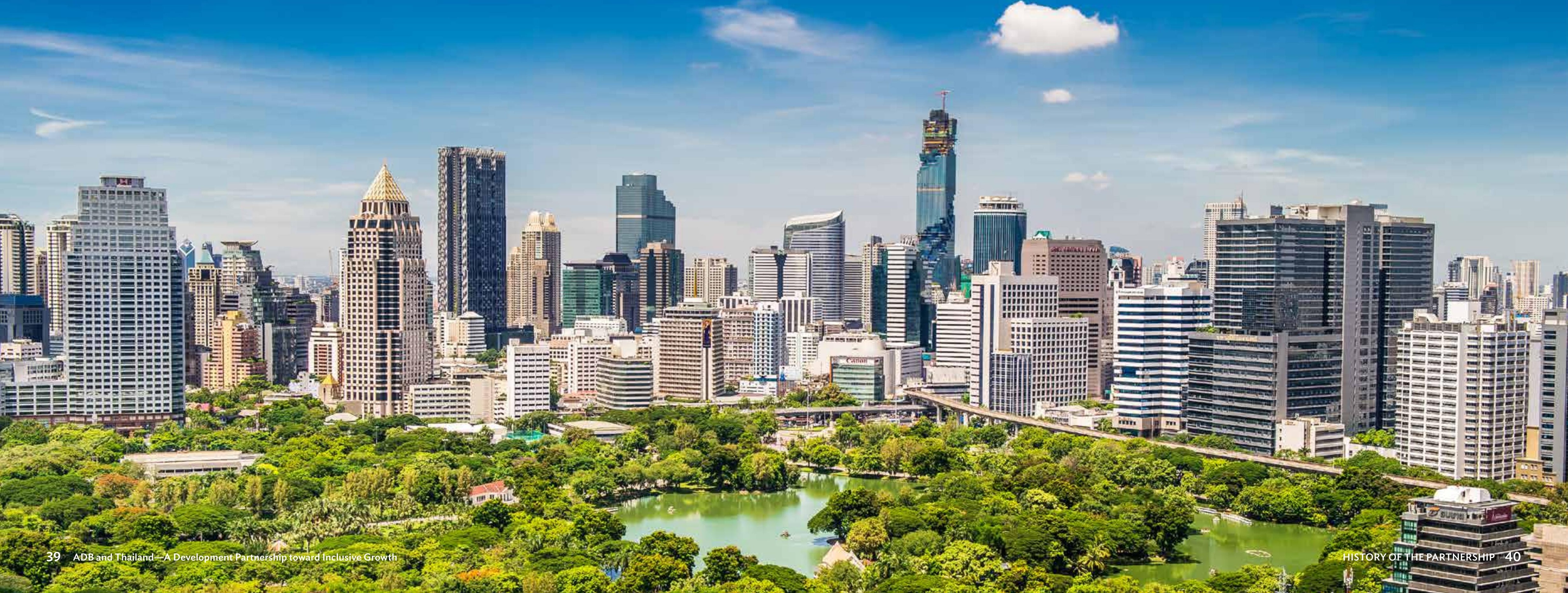


imes and more context-specific knowledge as economic, social, and political conditions were constantly evolving and deepening. Project coordination and implementation could also benefit from a staff presence on the ground, and the country operational interface provided by a resident mission would help to build networks, communication, and a relationship of trust. The 2000 ADB Resident Mission Policy also suggested that resident missions could play an enhanced role beyond in-country project administration, including enhanced policy dialogue and partnerships with DMC governments, increased responsiveness to local needs and issues, and intensified interaction with key stakeholders from the public and private sectors and civil society.

In March 2000, ADB approved in principle the establishment of resident mission in Thailand, to become operational in November that year, but the political environment at the time meant that this plan would not come to fruition for another 5 years. The Tha economy had already recovered quite strongly by the time of the 2001 election, to the extent that there was no great urgency to

Thailand, through the TRM, was also seen as a test case for continued ADB development assistance to acountry that had by then achieved assistance to a country that middle income status, building partnerships beyond a financial cooperation.
Thailand, through the TRM, was also seen as a test case for continued ADB development assistance to a country that had by then achieved middle income status, building partnerships beyond financial cooperation. Although Thailand has transformed to be an upper MIC, there were still many areas for continued improvement which could benefit from the pool of world-standard expertise available from and through ADB, and, indeed, continued financial assistance, including nonsovereign loans which, at the time, were a very limited component of ADB's loans which, at the time, were a very limited component of ADB's
portfolio. Providing development assistance to an upper MIC requires a fresh approach and mindset, with more imagination, innovation, and flexibility than is typically necessary with projectbased lending. The focus is on the deepening of development, no just the promotion of development. Thus, ADB's partnership with Thailand needed to adjust to the country's changing development circumstances and aspirations. The TRM has, thus, positioned itself as a knowledge hub as it continues to play a role in Thailand's advancement and modernization.

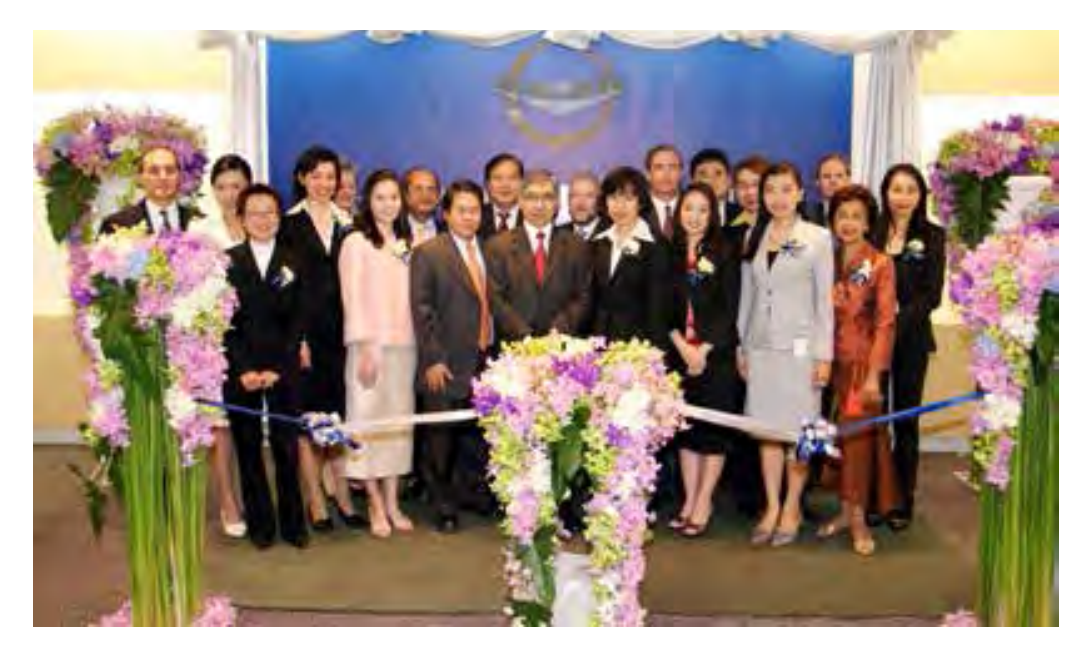

COUNTRY PARTNERSHIP STRATEGY BETWEEN ADB AND THAILAND, 2005 TO THE PRESENT

Thailand quickly recovered from the effects of the 1997 financial cisis and progressed to formally achieving the status of an MiC on 1 July 2011, when its gross national income per capita surpassed the threshold of $\$ 3,976$. Nevertheless, a great any development challenges remained. Thailand's economic rowth had centered on the rapid expansion of export-oriented dustrialization during the 1980s and 1990s, taking advantage oflow-cost factor inputs, especially of labor, to capitalize on the global shift in $\mathrm{m}$ But full employment, rising labor costs, and growing competition from other Asian countries meant that Thailand had to find new ways of competing on world markets to regain its competitive position in the post-crisis era. This meant supporting a shift from relatively low value-added labor-intensive manufacturing to higher value-added skills-, technology-, and innovationto higher value-added skills-, technology-, and innovation-
intensive forms of production linked to global value chains. For Thailand, this required considerable investment in education and human resource development. Thailand had achieved most of its Millennium Development Goals (MDGs) ahead of the 2015 targe date, but stubborn pockets of poverty remained in the countryside and lagging regions. The degradation of and the environment provided a further set of challenges for 
sustainable development. Pollution and congestion threatened to counterbalance quality of life gains from development and clog the arteries of economic efficiency. Further investment in infrastructure was essential to sustain the economic and social development of Thailand's urban-industrial core, and to hel spread the benefits of growth and transformation to the country's peripheral regions.

Thus, the development landscape and policy context into whic ADB's TRM was inserted was quite different from that which provided to ADB's activities before and during the financial crisis, The streng of to international capital markets determined that Thailand had limited need to borrow large sums of money from the IFIs to facilitate its domestic development. While no new ADB public sector loans were approved between 2000-2006, when TRM assistance and capacity building to Thailand. ADB's initiatives help the Thai public and private sector institutions gain access to the international knowledge, expertise, and experience tha were essential to the deepening and growing sophistication problems, the bu

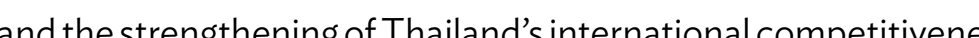
Thus, ADB and the government agreed on a country partnersh strategy (CPS), for development. The CPS identified well-defined

45 ADB and Thailand-A Development Partnership toward Inclusive Grovt
Guidance for ADB's first CPS for Thailand was provided by the 2011), which focused on inclusive and equitable development, continued poverty reduction, the promotion of sustainable development through environmental and natural resource management, good governance, the enhancement of local community economies and social protection systems, human and social development, and raising productivity and competitiveness. ADB activities in Thailand should also be consistent with ADB's own strategic planning framework for 2008-2020, as identified for ADB involvement in the country's development from 2007 to 2011 including infrastructure development, capital market and capacity building to Thailand. ADB's initiatives help the Thai public and private sector institutions gain access to the internationa knowledge, expertise, and experience that were essential to the deepening and growing sophistication of development interventions, the confronting of environmental problems, the building of institutional and operational capacity, and the strengthening of Thailand's international competitiveness. Tenth National Economic and Social Development Plan (2007in its Strategy 2020, ${ }^{2}$ and finalized at the same time that the CPS was being formulated. ADB's strategic framework identified infrastructure, environment, finance sector development core areas of development, environmentally sustainable development, and

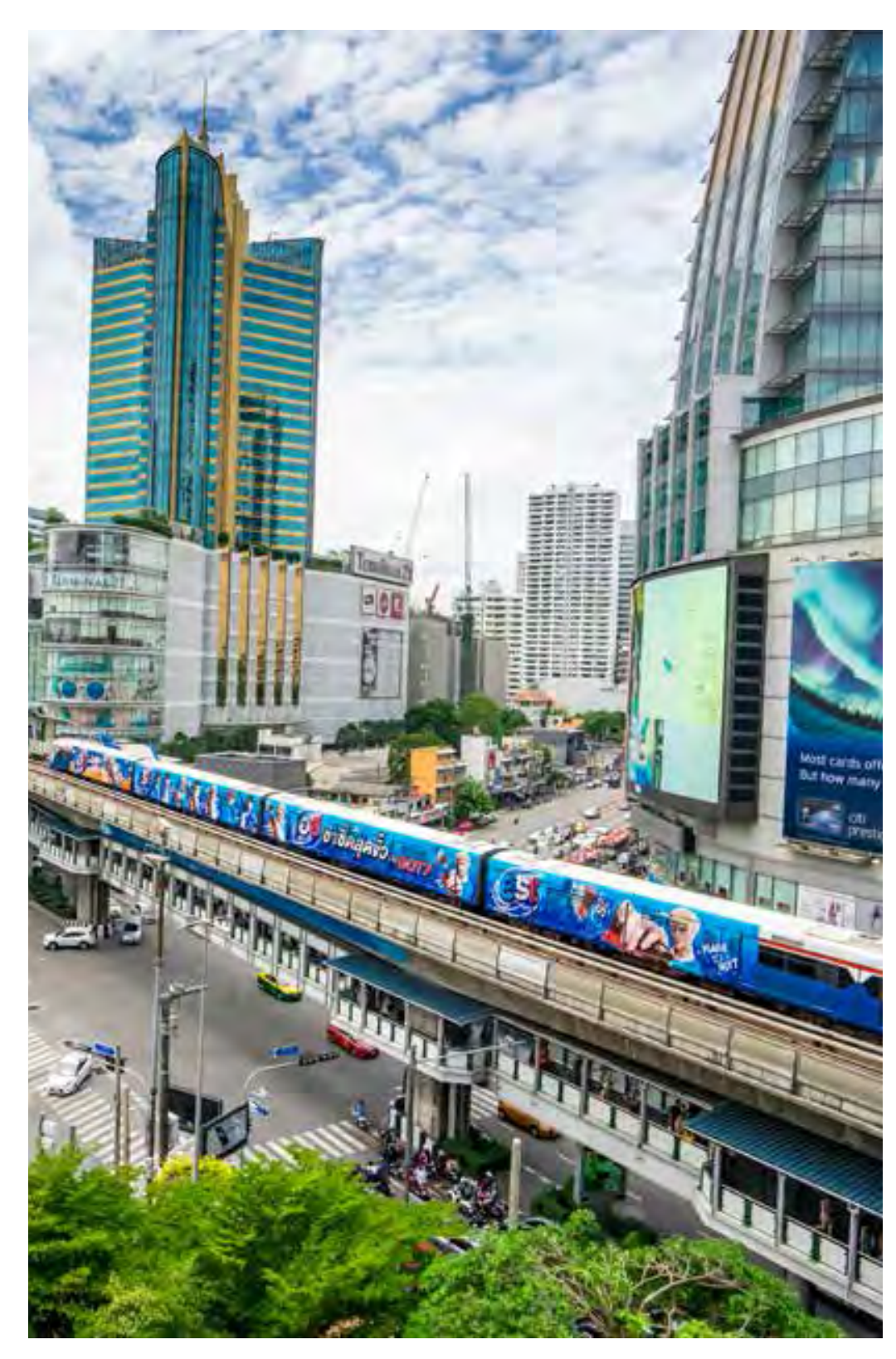

ADB. 2008. Strategy 2020: The Long
Development Bank, 2008-2020. Manila 


\section{Box 4: Infrastructure Development}

A key priority of both the Government of Thailand and the Asian Development Bank (ADB) focused on bridging the infrastructure investment gap by facilitating the involvement of the private sector fields of development, through joint ventures and public-private partnerships. The underlying rationale was twofold. to reduce the burden to the public purse and overcomelinitations of public funding, on the one hand; while drawing upon the financial resources, new technologies, and both logistical and operational efficiencies avaliable from the private sector, on the other. The priority areas for infrastructure investment following these principles are rail mass rapid transit systems, highway development, power generation, urban water supply, and sanitation. ADB would contribute knowledge and skills to the preparation of projects, including feasibility analyses; social and environmental assessments; and developing appropriate legal, operational, and regulatory frameworks for joint ventures and public-private partnerships. ADB would also be in a position to provide project loans for Thailand's infrastructure program using some of its new financial products designed specifically for middle-income countries, such as political risk and partial credit guarantees, local currency loans, and nonsovereign loans to municipalities.

Source: Asian Development Bank

\section{Box 5: Capital Market Development}

With Thailand aiming to finance more of its infrastructure and other forms of investment from domestic sources, there was a need to increase both the size and sophistication of the domestic capital market, and in particular to diversity the finance sector away from traditional banking. Accordingly, the partnership of the Asian Development Bank (ADB) with Thailand aimed to concentrate on developing the bond, equity, and derivative markets, as well as rationalizing the country's tax system and further strengthening finance sector regulation. The bond market would provide a conduit for the mobilzation of domestic savings and ohter inancial resources, and wold represent a competitive alternative to credit raised from commercial banks. ADB would help to build institutional and regulatory capacity in this underdeveloped segment of the Thai financial system. The derivatives market in Thailand was also in its infancy, but a futures market was opened in 2006 to provide an extra channel for domestic institutional investors and foreign interests to participate in the country's capital market. Although Thailand has had a stock exchange since 1975, the government wished to see its size and range expand, with more small and medium-sized enterprises and privatized state-owned enterprises listing on the Stock Exchange of Thailand. ADB would assist Thailand in developing regulatory mechanisms, surveillance and monitoring systems, and risk management provisions.

Source: Asian Development Bank.

47 ADB and Thailand-A Development Partnership toward Inclusive Growth

Box 6: Environmentally Sustainable Development

The Government of Thailand emphasized promoting energy efficiency and the expansion of clean energy technologies such as wind and solar factors such as sustainable utilization of natural resources for economic development and social welfare without compromising the integrity of environmental systems. The Asian Development Bank would also help the government to explore the potential for deploying economic instruments-such as taxation, user fees and surcharges-for environmental management and pollution control, instead of or as well as the more conventional command and control methods.

Source: Asian Development Bank

\section{CPS}

Country Partnership Strategy (CPS) betueen ADB \& Thailand 2007-2011

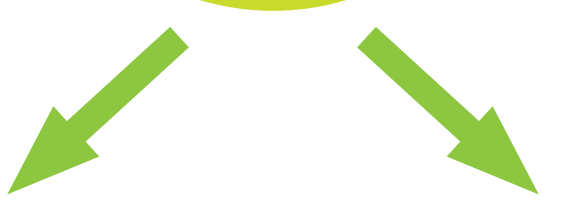

Box 7: Regional Cooperation and Integration

Thailand recognizes the economic benefits that will accrue from facilitating closer and more efficient logistical connections with neighboring countries, and also from playing a role in their economic development and diversification. It is an active founding member of the Association of Southeast Asian Nations, a pivotal hub of the Greater Mekong Subregion, and an integral part of several subregional blocs (e.g., Bay of Bengal Initiative on Multi-Sectoral Technical and Economic Cooperation, Indonesia-Malaysia-Thailand Growth Triangle, and AyeyarwadyChao Phraya-Mekong Economic Co-operation Strategy). Thailand has been channelling official development assistance to neighboring countries since 1992, contributing to poverty alleviation and sustainable development through two agencies: the Neighbouring Countries Economic Development Cooperation Agency (2005), and the Thailand International Development Cooperation Agency (2004), established as a successor to the Department of Technical and Economic Cooperation. The partnership strategy for regional cooperation and integration concentrates the following elements: cross-border infrastructure, especially that supporting transborder economic corridors; subregional and transborder trade and investment; money and finance; and regional public goods, such as health and environmental protection; ADB support on Thailand's role in cofinancing development projects in the subregion.

Source: Asian Development Bank. 
The early stages of the first CPS were adversely affected by provision of sovereign and nonsovereign loans to the channelling the global financial crisis in 2008, and later compounded by protracted political unrest in 2010, and severe flooding in 2011, which coincided with the end of the CPS. ADB's strategic support for Thailand's development during this period adapted to thes changing circumstances, none of which could easily have been foreseen when the CPS was being drafted.

Competitiveness and sustainability continued to be important strategic keywords in ADB's second CPS, 2013-2016, which mirrored similar objectives in the country's 11th national plan, development and good governance, as a result of the political divisions in 2010. ADB support to Thailand under ADB's second CPS aimed to follow ADB's "finance ++" model, which links the porticy advice, and the leveraging of dditional financing from both public and private sources. The second CPS centered on three strategic pillars: (a) knowledge dvancement, and innovation, whereby ADB would use its exper knowledge resources to facilitate policy reform and business development through partnerships with a range of stakeholders (b) pivate sector devel 列 sectors to strengthen the business environment and enable public-private partnerships (PPPs); and (c) facilitation of RC encouraging regional connectivity of production, distribution transportation, and energy systems and of capital and labor Crosscenting issues, which underph the achiven

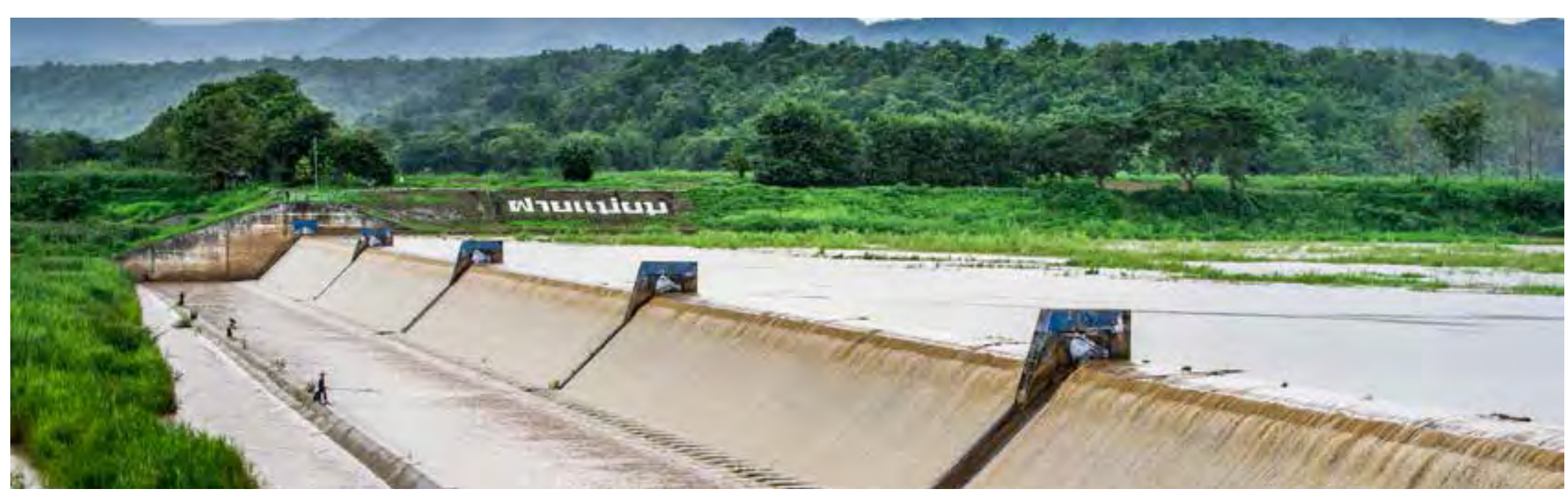

49 ADB and Thailand-A Development Partnership toward Inclusive Growt

these strategic objectives, are human resource development and institutional capacity-building, and the promotion of gender equality by integrating gender analysis into all strategic initiatives. Improvementin governance is an important focus of ADB activities through helping to improve planning, procurement, and financial management, as well as strengthening anticorruption measures and promoting transparent decision making and regulations.

Important loans during the two CPSs were the GMS Highway Expansion Project in 2009 (\$77.1 million) and the Capital Markets Development Program in 2010 ( $\$ 300$ million). Additionally, AD contributed \$3 million from its Asia Pacific Disaster Response Fund to help with the costs of flood relief, and organized an international knowledge-sharing forum in Bangkok to exchange experiences about flood management, response, and prevention in January 2012

ADB subsequently provided technical support for the government's Master Plan on Water Resource Management which incorporates principles of integrated water management. ADB has also contributed to the development of an integrated water resources management modeling tool, based upon a pilot study in the Yom River Basin, which will be rolled out to 25 other river basins in Thailand by the Department of Water Resources. For transport sector, ADB also has continued to make a major contribution to the improvement of the country's road and rail systems through various ADB technical assistances. road and rail systems In addtion, ADB has provided an advisory support to facilitate private sector involvement in economic and social infrastructure investment. Financial inclusion was added to the priority a crisis and domestic political unrest, which was partly linked to socioeconomic inequality amplified by the crisis. The government also explored the possibility of further borrowing from ADB to support the country's infrastructure development and financia renewable approved in 2010-2015

$A D B$ has engaged not only with the government and private sector counterparts, but also with Thai civil societies. ADB has recently cooperated with a leading nongovernment organizatio in Thailand to promote good governance and anticorruption in the country. Key activities included knowledge-sharing to raise awareness of good governance among the country's youth, and capacity development to create an integrity pact to fight corruption in public procurement.

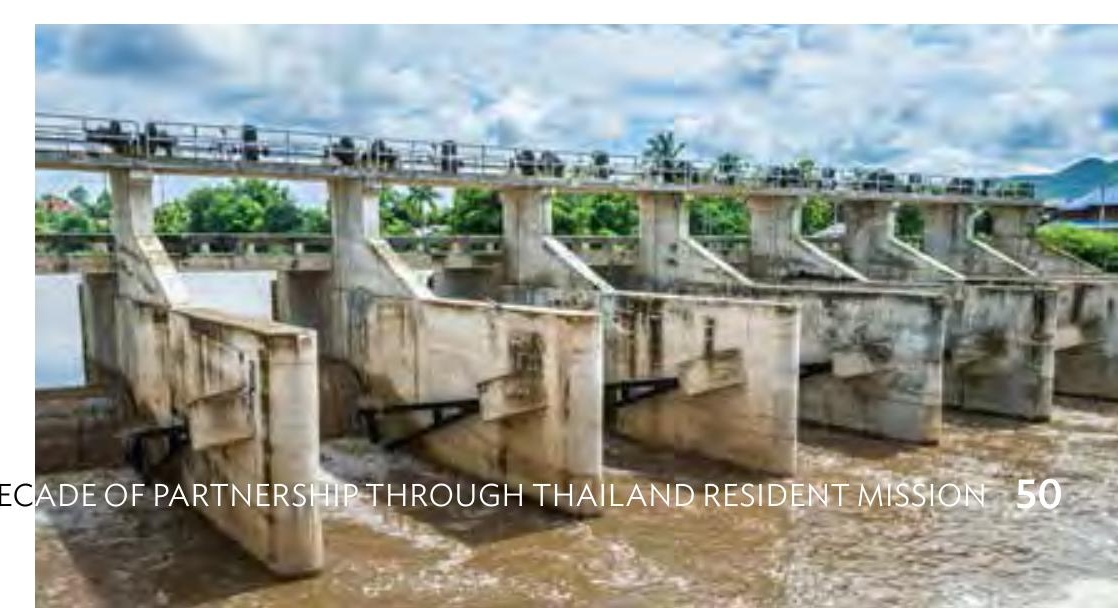


Table 8: Technical Assistance to Thailand since Inauguration of ADB's

Thailand Resident Mission

\begin{tabular}{|l|l}
\hline TAN \\
4558 \\
4564 \\
46 \\
4667 \\
\\
4676 \\
4826 \\
4886 \\
4904 \\
7044 \\
7050 \\
7070 \\
7102 \\
7133 \\
7194 \\
7483
\end{tabular}

Project Name

Commercial Financing for Local Government Units

Approval Date

Status Report on the Asian Tsunami Fund (January-June 2007)

Subregional Development Plan for the Tsunami-Affected Andaman Region

Capacity Building for Pollution Taxation and Resource Mobilization for Environment and Natural Resources-Phase II

Infrastructure Investment Advisory Assistance to the Public Debt Management Office of Thailand

Support for Implementation of the New Capital Market Development Master Plan

Capacity Building for the Neighbouring Countries Economic Development Cooperation Agency Infrastructure Investment Advisory Assistance (Phase II)

Preparing the Bangkok Mass Rapid Transit Integrated Ticketing Project Planning for the Sustainable Development of Southern Thailand

Greater Mekong Subregion Highway Expansion Project

Capital Market Development Phase II

Capacity Building and School Networking for Educational Services (e-Learning)

Mainstreaming Energy Efficiency Measures in Thai Municipalities

Implementation Plan for Strategic Intercity Motorway Network Project
TA No.

7540

7602

7615

7863

796

7998

8078

8183

8194

2007

2008

Deloment Partnership toward thetesie Gorth

Project Name

Mainstreaming Public-Private Partnerships

Capital Market Development Program

Bangchak Solar Power

Enhancing Strategic Alignment in the Thailand-ADB Partnership

Support for Flood Management Knowledge Forum

Development of a Strategic Framework for Financial Inclusion

$$
\text { Supporting Railway Sector Reform }
$$

Improvement of Railway Passenger Services

Accounting and Financial Management System Reform of Thailand's Railway Sector

Thailand Intercity Motorway

Strengthening Integrated Water and Flood Management Implementation

Piloting Public-Private Partnerships in the Social Sectors

Advancing National Financial Literacy

Strengthening Financial Transparency of Specialized Financial Institutions

Strengthening Specialized and Semi-Formal Financial Institutions to Support Financial Inclusion 
Climate Change Mitigation and Environment

ADB's Strategy 2020 recognizes the stresses and strains that economic growth and lifestyle improvements have placed on ecosystems, natural resources, and essential ecological processes, and also the extent to which local and national development processes have global implications through their contribution to greenhouse gas emissions and climate change. The Asia and Pacific region accounted for $47.2 \%$ of global carbon dioxide emissions in 2015, more than half of which came from electricity generation. Primary energy demand in Asia and the Pacific is projected to grow at 2.1\% per year from 2010-2035, compared with a world average rate of $1.5 \%$ per year. Environmentally sustainable growth is, thus, one of ADB's three critical strategic agendas for the period 2008-2020 (the othertwo being inclusivegrowth and RCI). To help achieve this objective, ADB is contibuing knowledge, expertise, and financial resources to disseminate technologies and organizational best practice in environmental management and safeguarding, as well as strengthening institutional capacities for environmental legislation and enforcement. ADB assistance for environmental management in Asia focuses on two key areas: climate change mitigation and livable cities. The former provides the principal focal area for ADB's activities in Thailand, emphasizing improvements in energy efficiency, expanding the use of clean and renewable energy sources, and modernizing both public and private transport systems.

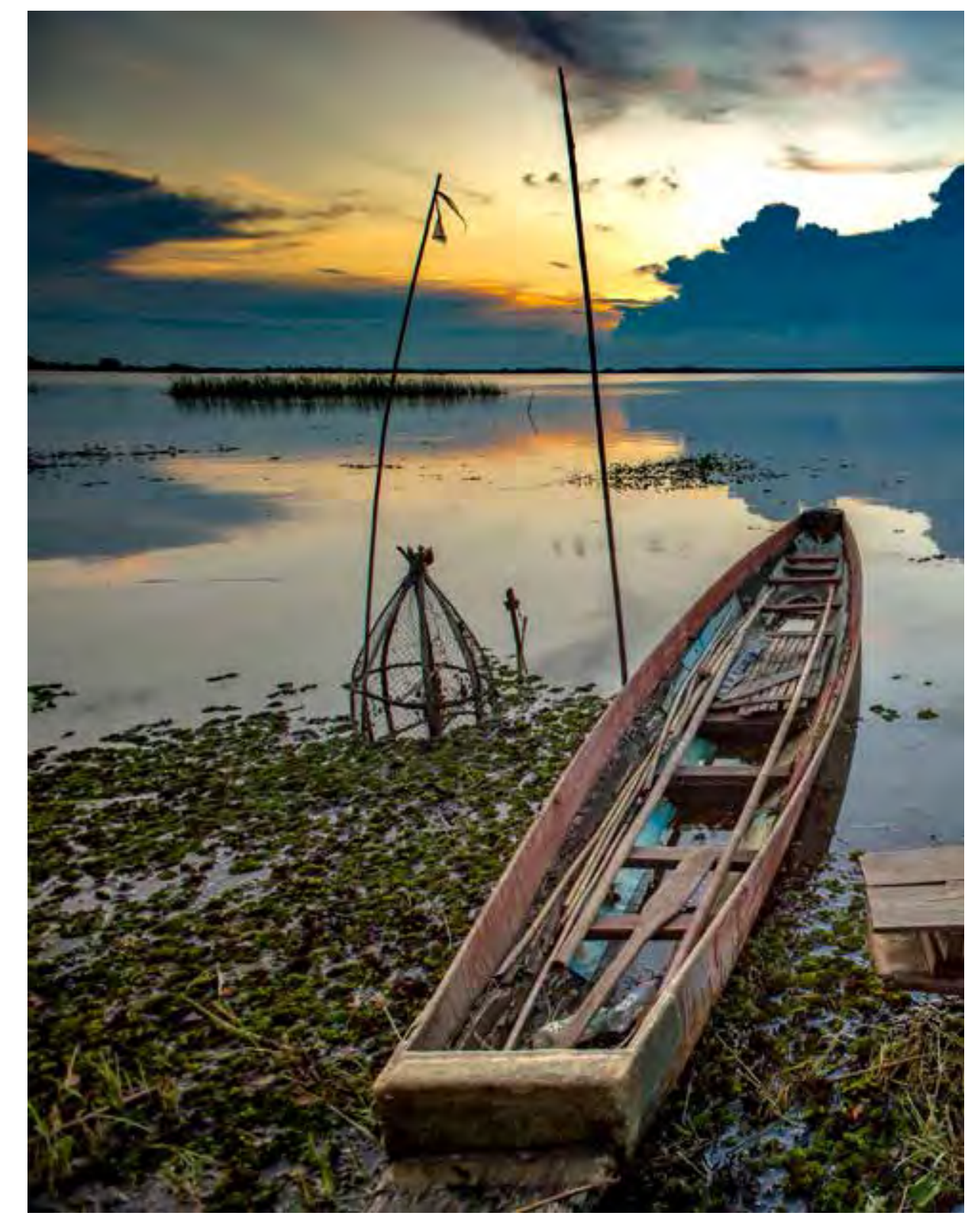

Table 9: Energy Consumption in Thailand, 2013

\begin{tabular}{|c|c|c|}
\hline Energy Source & $\begin{array}{l}\text { Kilotons of Oil } \\
\text { Equivalent }\end{array}$ & $\%$ \\
\hline Lignite and coal & 5,947 & 7.91 \\
\hline Petroleum: & 35,948 & 47.79 \\
\hline fossil fuels & & 95.50 \\
\hline biofuels & & 4.50 \\
\hline Natural gas & 5,339 & 7.09 \\
\hline Electricity: & 14,626 & 19.45 \\
\hline fossil fuels & & 80.00 \\
\hline renewables & & 9.20 \\
\hline imported hydropower & & 7.70 \\
\hline large hydropower & & 3.10 \\
\hline Renewable energy & 5,278 & 7.02 \\
\hline Traditional renewable energy fuelwood, biomass & 8,076 & 10.74 \\
\hline Tota & 75,214 & 100.00 \\
\hline
\end{tabular}

Source: Ministry of Energy, Department of Alternative Energy Development and Efficiency. 
Thailand's energy consumption grew at an average annual rate of 4.4\% between 1990-2010, while the economy grew at an annual average of $4.5 \%$ over the same period, giving an energy elasticity of 0.98 , which is considered high in comparison with countries a similar level of development, given an average energy elasticity of $0.5-0.6$ for the Organisation for Economic Co-operation and Development countries over a similar period. Thailand relies very heavily on fossil fuels for the energy needed to keep industry moving, transport flowing, and households functioning, but $67 \%$ of the country's energy demand was met through imported energy sources in 2012, at a cost of $\$ 71$ billion. Promoting greener and renewable domestic energy sources, thus, represent an essential tep toward reducing the country's carbon footprint as well as improving the country's energy security. However, such actions are meaningless if total per capita energy consumption continues to increase and green energy simply becomes an additional, rather than an alternative means of providing energy. Improving energy efficiency is, therefore, an essential element of an energy strategy for sustainable economic development In 2011 Thiltond introduced a 20-year Energy Efficiency Development Plan, which set energy conservation targets for the industrial, transport, commercial and residential sectors. The plan was revised by the National Energy Policy Committee in 2015 (2015-2036). The overarching target was to reduce energy intensity (energy use per unit of gross domestic product) by $30 \%$ across all economic project's original targets, and successfully

demonstrated the scope for energy savings in urban areas.
ADB has been lending support to the Government of Thailand's energy efficiency promotion efforts as part of its own Energy Efficiency Initiative, contributing expertise in the form of TA, as well as developing strategies and action plans, and helping to build institutional capacity. A particular focus has been on improving energy efficiency at the municipal level. A policy and advisory TA on Mainstreaming Energy Efficiency Measures in Thai Municipalities commenced in 2009, funded with a gran of \$1 million from the Multi-Donor Clean Energy Fund. This provided a range of knowledge-based inputs to the Provincial Electricity Authority (PEA), which accounts for more than 65\% all electricity consumed in Thailand, to help identify the technica, financial, and institutional measures necessary to mainstream energy conservation measuresin municipalities across Thailand it focused in theminonanumber of which included retrofitting municipal buildings and upgradin public street lighting using light-emitting diode technologies. Building retrofits in public buildings achieved energy savings level between $25 \%$ and $50 \%$, greatly exceeding the project's original savings in urban areas The pilot street lghting proj savings in urban areas. The pilot street lighting projects in Tran Municipality using light-emitting diode roadside lamps achieved a significant improvement in light output quality using $40 \%$ $50 \%$ less energy consumption. The PEA quite heavily subsidizes the costs of municipal street lighting and thus also has a strong incentive to intreduce more efficient and thus also has a strong incentive to introduce more ef also helped the PEA to develop a plan for replicating, expandin and scaling up the energy efficiency program to municipalities cross Thailand. A handbook for implementing energy efficienc than 2,000 municipalities across Thailand.

\section{Clean Energy}

Thailand's 2015 Power Development Plan anticipates an increase in peak electricity generation demand between 2016 and 2036 from 30,218 megawatts (MW) to 49,655 MW, an increase of $64 \%$ at an average annual growth rate of $2.51 \%$, which provides a significant challenge to Thailand's commitment to reduce greenhouse gas emissions. In 2008, the Government of Thailand introduced an Alternative Energy Development Plan (AEDP), 2008-2022, which set a target of 20.3\% for primary commercia energy from renewable energy sources by the year 2022. To achieve this objective, a number of impediments have to be overcome. There is a need to extend and improve the transmission, distribution, and storage systems for electricity sources such as solar and wind, which typically occur in locations that are isolated from conven electricity-generating sources, and may typically be much smaller in scale. Laws and regulations need to be introduced or amended to facilitate these alternative energy sources, and the process of granting power purchase concessions needs to be speeded up. Several of these renewable energy sources have high initial investment costs and relatively longlead- 
in times, which may make them less attractive to private sources of finance. Also, because of localization and scale diseconomies, the cost of the energy produced may be greater than tha from conventional commercial energy sources, leading to disadvantageous competitive position in the energy marketplace. To overcome some of these constraints, the Ministry of Energy, in conjunction with other ministries and departments, is seeking to provide a number of incentives, such as waiving import duties for equipment; providing relief on corporation tax, grants, and credit guarantees; and paying premium feed-in tariffs for electricity sold to the grid.

\section{Solar Power}

ADB's 2009 Energy Policy complements the Government of Thailand's objectives under the AEDP in seeking to contribution of renewable energy by helping DMCs gain access to the requisite technology and financing, as well as supporting policy, regulatory, and awareness-raising efforts. In 2010, ADB committed itself to invest $\$ 2$ billion a year in clean energy as part of its Asia Sola Energy intiative, which aimed to realize $3000 \mathrm{MW}$ solar energy in Astin DMCs by 2013. In Thall d, the Depatnet of Energy in its latest AEDP, 2015-2036, aims to install 6,000 MW of solar power capacity by the year 2036 . Solar power has been one of the fastest-growing electricity technologies in recent years, but member countries such as Thailand face significant constraints in their efforts to capitalize on the sector's energygenerating potential. To date, few DMCs have developed the cells, which mus a cost to foreign exchange reserves. An emerging energy sector also requires organizational, regulatory, and attitudinal shifts, and both mechanisms and incentives for private sector developers to raise the required investment capital. The Government of

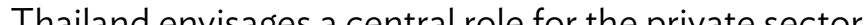
the country's potential for solar energyention At present is advocating a decentralized strategy whereby relatively small-scale producers in suitable localities will construct and operate power projects to be fed into the grid via power purchase agreements with the state-owned electricity distributors, i.e., EGAT, PEA, and the Metropolitan Electricity Authority.

As part of its decentralized power generation strategy, the Ministry of Energy supports two localized solar power programs

$A D B$, via $T R M$, is playing a pioneer role in helping Thailand to mobilize its solar power resources, providing solar project with 18-year local currency loans which

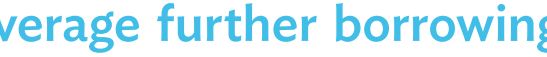
from commercial sources with limited experience in clean energy projects.

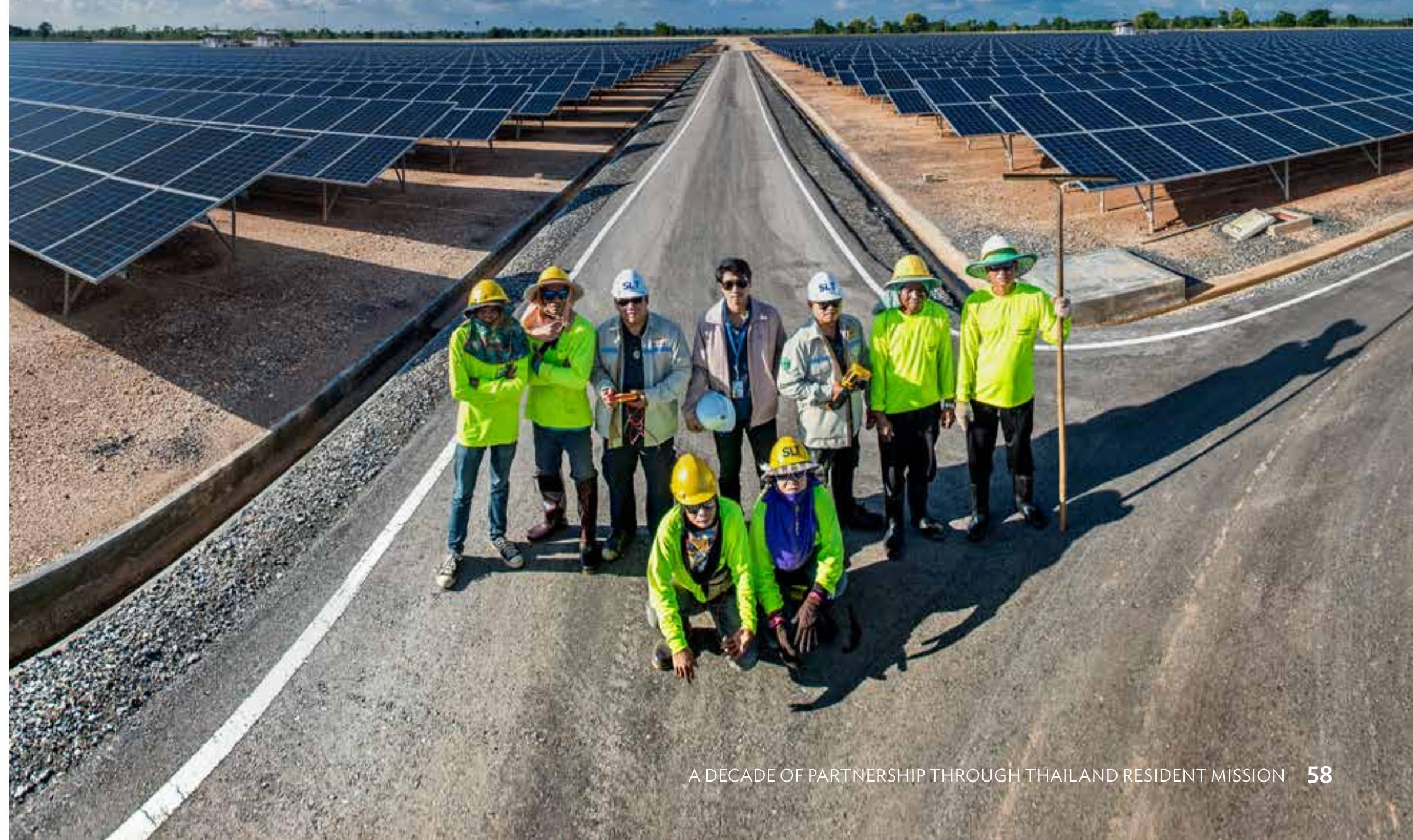


Involving small power producers (SPPs) (10 MW-90 MW power ( to $10 \mathrm{MW}$. As of 2009 , SPPs accounted for $10 \%$ of the country's total power generation, and VSPPs an additional $1 \%$. EGAT offered these firms a supplementary or adder tariff of $\mathrm{B} 8.00$ per kilowat hour $(\mathrm{kWh})$ for 10 years from the start of commercial operation, as a subsidy to offset current commercial disadvantages of smalscale renewable energy production (this figure has subsequently dropped to B6.50 per kWh in 2011). The problem that many small renewable energy producers face, which prevents them from entering the market, is not the adder tariff so much as the 10-year incentive period. Given the high up-front investment costs and the level of risk of investing in an energy sector at the early stages of its development, the incentive structure is not yet attractive enough in the longer-term to offset the costs and perceived risks involved. $A D B$ is trying to change this situation by demonstrating to the private sector the viability and longer-term sustainability of operating in the renewable energy sector through the projects is supporting, and through the concessional funding it is able to provide from the ADBClean Technology Fund (CTF). ${ }^{3}$ Meanwhile, EGAT has moved away from adder incentives to feed-in tariffs in 2014, which guarantee a fixed rate of return over a 25 -year perio

${ }^{3}$ The CTF provides concessional financing to support the deployment of lowgas emissions over the long term. It is one of the largest funds helping DMCs fill gaps in financing projects to mitigate climate change.
$A D B$, via the TRM, is playing a pioneering role in helping Thailand were finding it difficult to raise the necessary long-term finance, en very high up-front costs set against relatively long breakeven horizons. Commercial banks would rarely provide loans for more than 10 years, whereas solar power requires much longer tenors. ADB provided solar projects with 18 -year local currency lo commerial sources, which hadinited experencein cren ener projects. Support for solar power generation has also provided timely conduit for $A D B$ to increase its direct nonsovereign lending to the private sector, helping to make ADB's Private Sector Operations Department's lending portfolio in Thailand one of the largest in Soutest Asia. ADB's first solar power project in Thailand, approved in 2010 , is contributing up to $\$ 70$ million or $25 \%$ of the total project costs of a $55 \mathrm{MW}$ SPP solar farm in Lopburi province, central Thailand, using thin-film photovoltaic panels, which at that time was the largest solar project using such technology in the world The project also qualfied for grant of $\$ 2$ million from the Clean Enegy Fund under the $\mathrm{Cl}$ a Energy Financing Parneship Facily 4 The pro driven by the Natural Energy Development Company, a limited company incorporated in Thailand. EGAT has entered into 5-year,

The grant is an ADB standby facility to finance any construction cost overruns
and, thereby, reduces a project's financial risks. The grant was not used because the project was completed on time and within budget.
ADB's first solar power project in Thailand, approved in 2010 , is contributing up to $\$ 70$ million or $25 \%$ of the total project costs of a $55 \mathrm{MW}$ SPP solar farm in Lopburi province, central Thailand, using thin-film photovoltaic panels, which at that time was the largest solar project using such technology in the world.

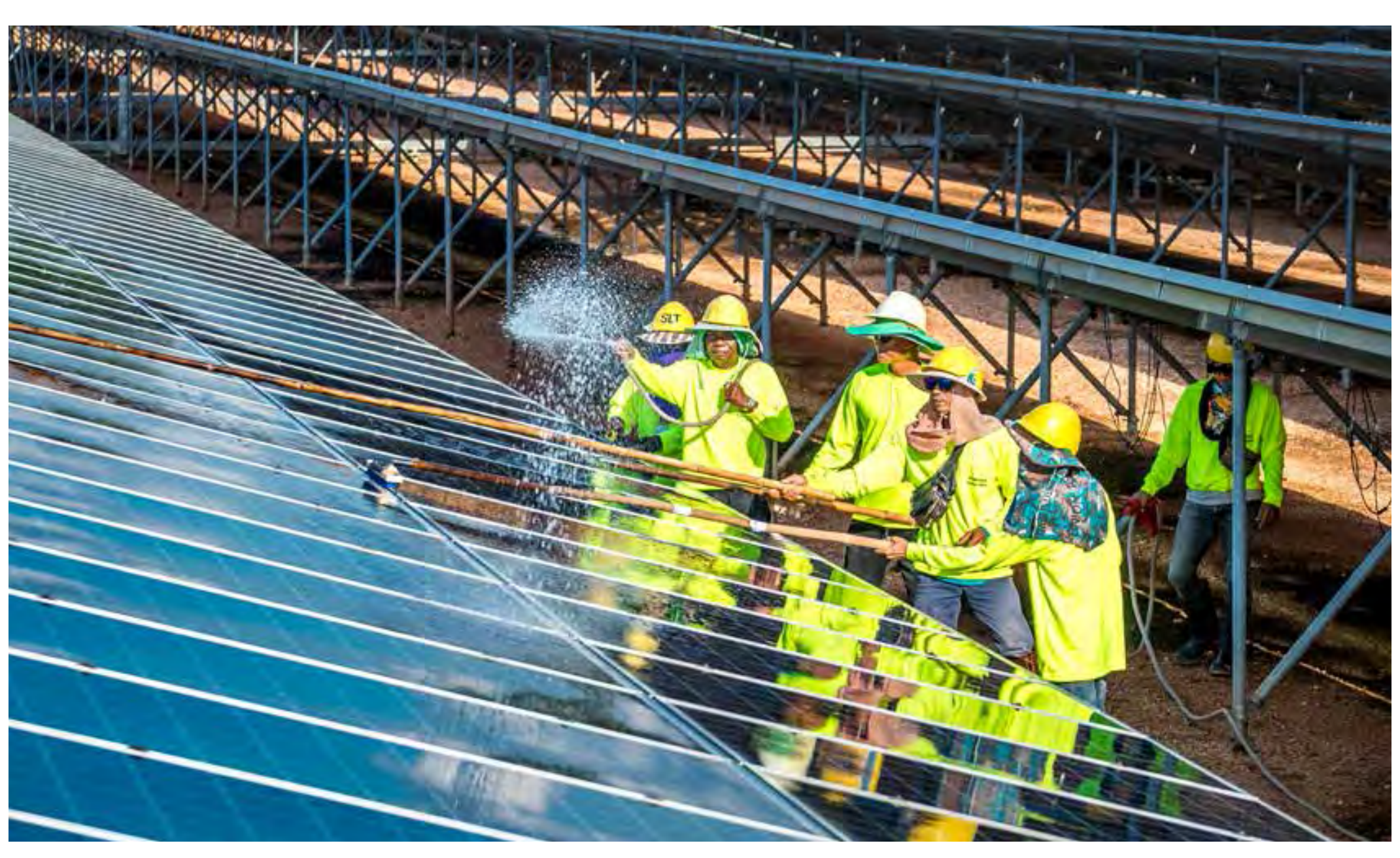


automatically renewable power purchase agreements with the Natural Energy Development Company. The project is the first utility-scale private sector power plant in Thailand. It achieved a Most Successful Project Award from the oversight body Independent Evaluation in 2016, which commented "the project was at the forefront of Thailand's renewable energy finance market, and provided a demonstration example for the local banking market to replicate and advance similar transactions." The project generated employment for 1753 local people during the construction stage, provided 150 scholarships for local students, and built a learning centre featuring both Lopburi heritage and the principles of renewable energy.

$A D B$ is involved in similar arrangements for three more solar power projects in Thailand. The first two are solar power plants with a total capacity of $44.5 \mathrm{MW}$ in Ayutthaya province, central Thailand, in collaboration with the Bangchak Petroleum Public Company (BCP), one of Thailand's largest oil refining and marketing companies. The solar farm, consisting of over 150,000 polycrystalline photovoltaic panels, is located adjacent to BCP's biodiesel plant in Bang Pa-In, $50 \mathrm{~km}$ north of Bangkok. ADB is providing a long-term local currency loan (of up to $\$ 134.3$ million), which provides $\mathrm{BCP}$ with the tenor required to fund a power generation plant with high up-front investment costs and a long asset life. The project loan was accompanied by a $\$ 400,000$ capacity development TA grant to support the implementation of carbon-neutral strategies within private sector energy companies in DMCs.

61 ADB and Thailand-A Development Partnership toward Inclusive Growt
ADB made a further nonsovereign loan of $\$ 25.2$ million to a BCP subsidiary, the Bangchak Solar Energy Company Limited, together with a loan of up to $\$ 15$ million from the ADB CTF for the Provincial Solar Power Project in Thailand. Bangchak Solar Energy Company Limited plans to become one of the largest solar power-producing company in the country. The Provincial Solar Power Project is the first component of this strategy, and consists of two 8 MW solar power farms in Chaiyaphum province and a further two $8 \mathrm{MW}$ solar farms in the Ayutthaya province. The four solar farms commenced commercial operations in 2013. A fourth ADB-funded solar project involving the private sector in Thailand is the 57 MW Central Thailand Solar Power Project, in partnership with Solarco Company Limited, in Nakhonpathom and Suphanburi provinces. ADB support consists of a loan of $\$ 52$ million, and up to $\$ 35$ million of concessional funding from the ADB CTF.

Wind Power

Wind energy is expected to meet up to $10 \%$ of global electricity demand by 2020, and the wind energy potential in Asia is estimated to be 2 million MW. Asia is the fastest-growing wind power market in the world. In 2011, ADB introduced its Quantum Leap in Wind Initiative, a regional capacity development TA for Asia financed from the Clean Energy Fund under the Clean the mobilization of wind energy potential by helping to remove constraints to finance, improve the identification and mapping of wind power resources, develop strategic frameworks for wind energy development, and share technical and operational knowledge cross-regionally. The initiative set a target of 1 gigawat of wind energy in Asia (excluding the PRC and India) in 5 years. To achieve this target, $A D B$ is seeking to ease a number of constraints on the sector's growth, such as insufficient grid infrastructure, a lack of local capacity to build and manage wind farms. ADB's wind power and renewable energy support program aims to help build a critical mass of first generation renewable energy projects in Thailand to catalyze long-term private sector involvement in the sector. To this purpose, ADB makes available concessional funding from its CTF, as well as conventional loans to a sector where private investment has been relatively hard to secure.

Thailand has the theoretical potential to generate $14,141 \mathrm{MW}$ of electricity from wind turbines, but by July 2015, wind-generated power totalled just $225 \mathrm{MW}$. As part of its AEDP, the government plans to increase this to 1,200 MW by 2021 and to 3,002 MW by 2036. EGAT offers adder premiums of B3.50 per kWh for SPPs producing more than $50 \mathrm{kWh}$, and B4.50 for VSPPs producing less than $50 \mathrm{kWh}$.

The Theppana Wind Power Project in Chaiyaphum province, pilot VSPP producing $75 \mathrm{MW}$, was ADB's point of entry to the wind energy sector in Thailand, and was also ADB's first wind 


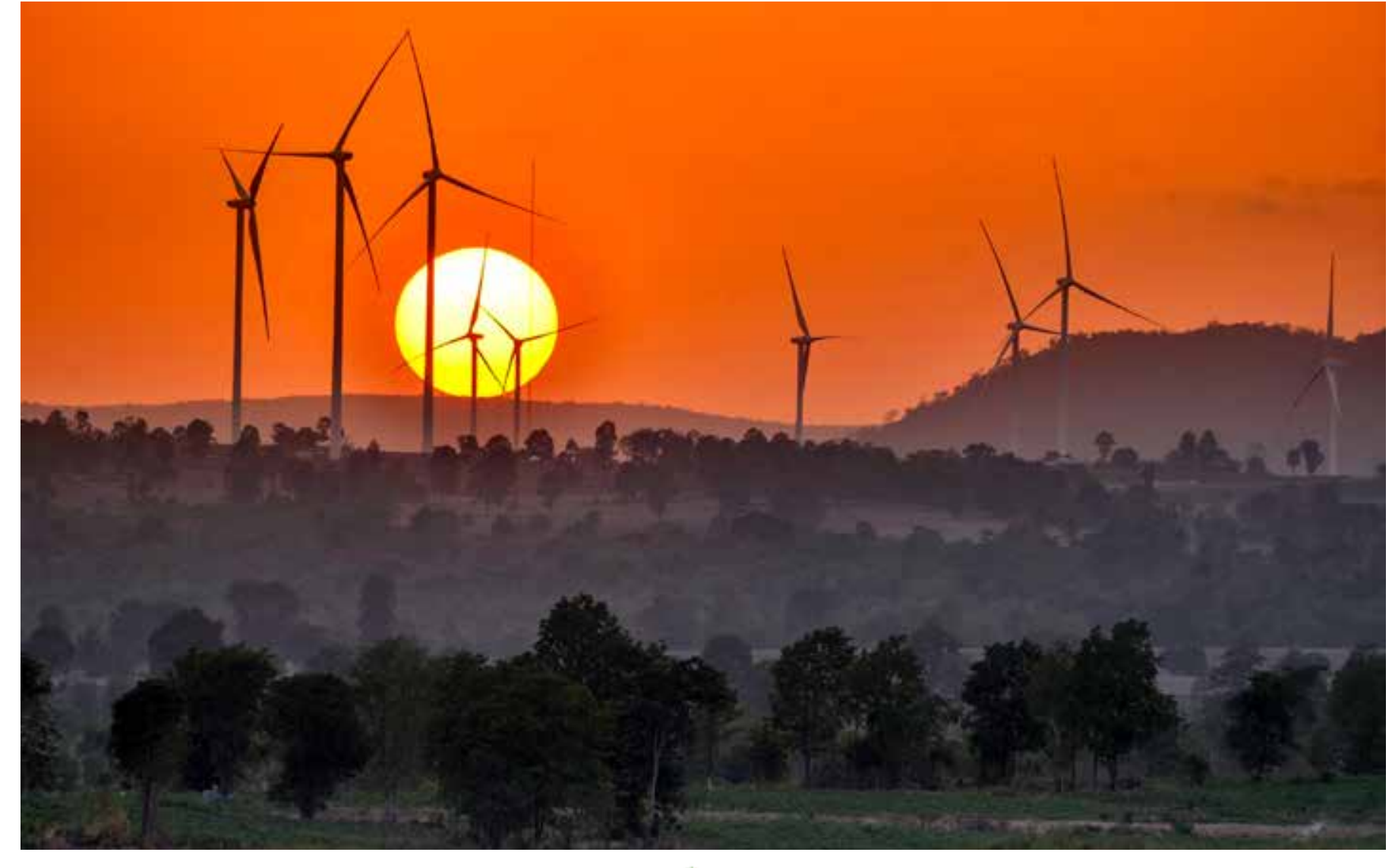

Photo Credit: Electricity Generating Public Company Limited EGoco

ADB's renewable energy support program aims to help build a critical mass of first generation ergy projects in Thailand to cata sector. To this purpose, ADB makes available concessional funding from its CTF and conventional loans to a sector where private investment has been relatively hard to secure.

63 ADB and Thailand-A Development Partnership toward Inclusive Growt power financing project in Southeast Asia. At the time, in January 2012, Thailand was only producing 7.28 MW of electricity from wind turbines. The Theppana Wind Power Project was intended to serve as a pilot project for Electricity Generating Power Company's (EGPO) entry into wind power generation and was intentionally structured on a limited-recourse basis to provide a sound financing structure that can be replicated by the muchJect planned in 2013 The project was fin (a) $\$ 4.54$ millon and supplemented by concessionary funding of $\$ 4$ million from the ADB CTF. For

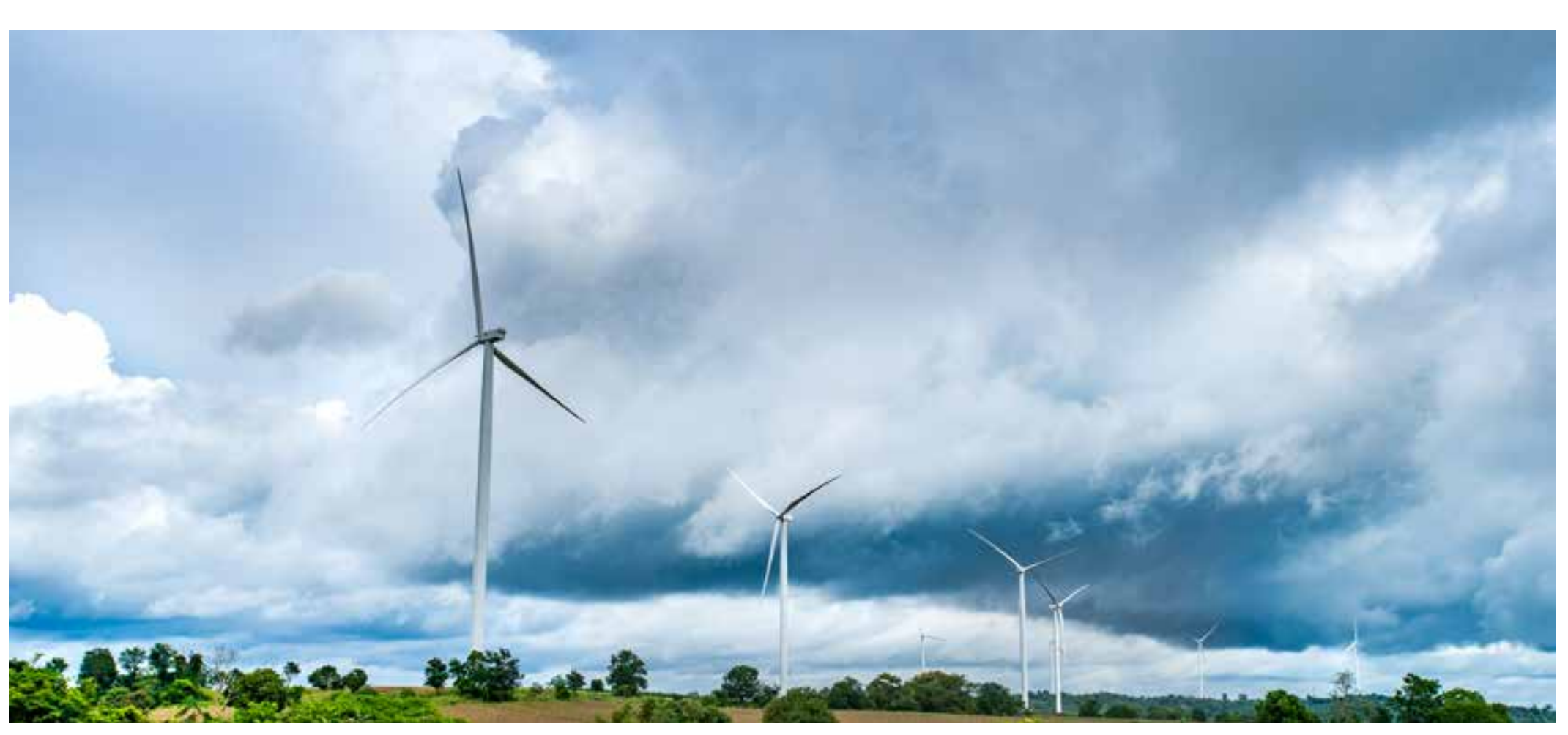

$A D B$, the project served the dual purpose of demonstrating the viability and sustainability of a utility-scale wind power project, and of moving toward meeting ADB's Private Sector Operations Department target of $25 \%$ of its annual project approvals, by number, to clean energy projects concerned. During the 11-mont construction of the wind farm, 250 local workers were employed. The project's initial environmental assessments and initial poverty requirements. 


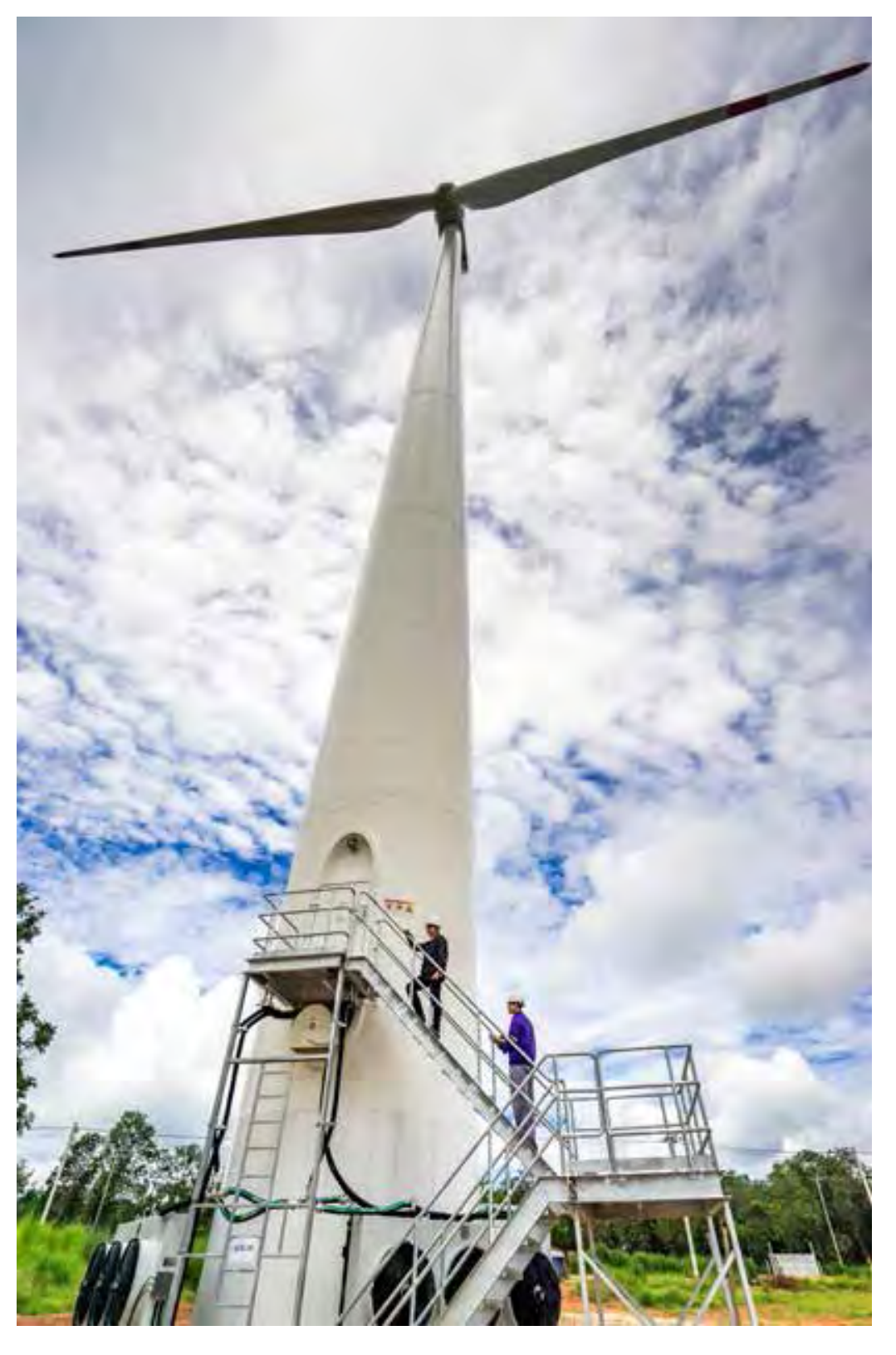

Subyai Wind Power Project, approved by ADB November 2014, and used the same financial structure that had been developed by ADB for the Electricity Generating Power Company, was a larger extension of the Theppana Wind Power Project, and which used the same financial structure that had been developed by ADB for the Electricity Generating Power Company. lectricity is delivered to the PEA under a 5 -year automatically newable power purchase agreement, which pays the wholesale ars of conmeriloperion, $250 \mathrm{local}$ workes weree during the construction phase. ADB support consists of a loan of $\$ 53$ million, and up to $\$ 30$ million of concessional funding from e ADB CTF.

inally, the much larger Northeast Thailand Wind Power Project is expected to come on-stream in mid-2018. It is a $260 \mathrm{MW}$ project run by Energy Absolute, the largest private renewable nergy firm in Thailand. The project consists of five separate components each in Chaiyaphum province, run by five subsidiary companies of Energy Absolute. The facilities will be built on three sites, generating $80 \mathrm{MW}, 90 \mathrm{MW}$, and $90 \mathrm{MW}$, respectively, of electricity. It is being financed by a loan of $\$ 157.50$ million from ADB and concessionary funding of $\$ 18.9$ million from the ADB CTF. It is the fifth project under the ADB CTF in Thailand, and completes ADB's allocation of the $\$ 100$ million in renewable energy financing.

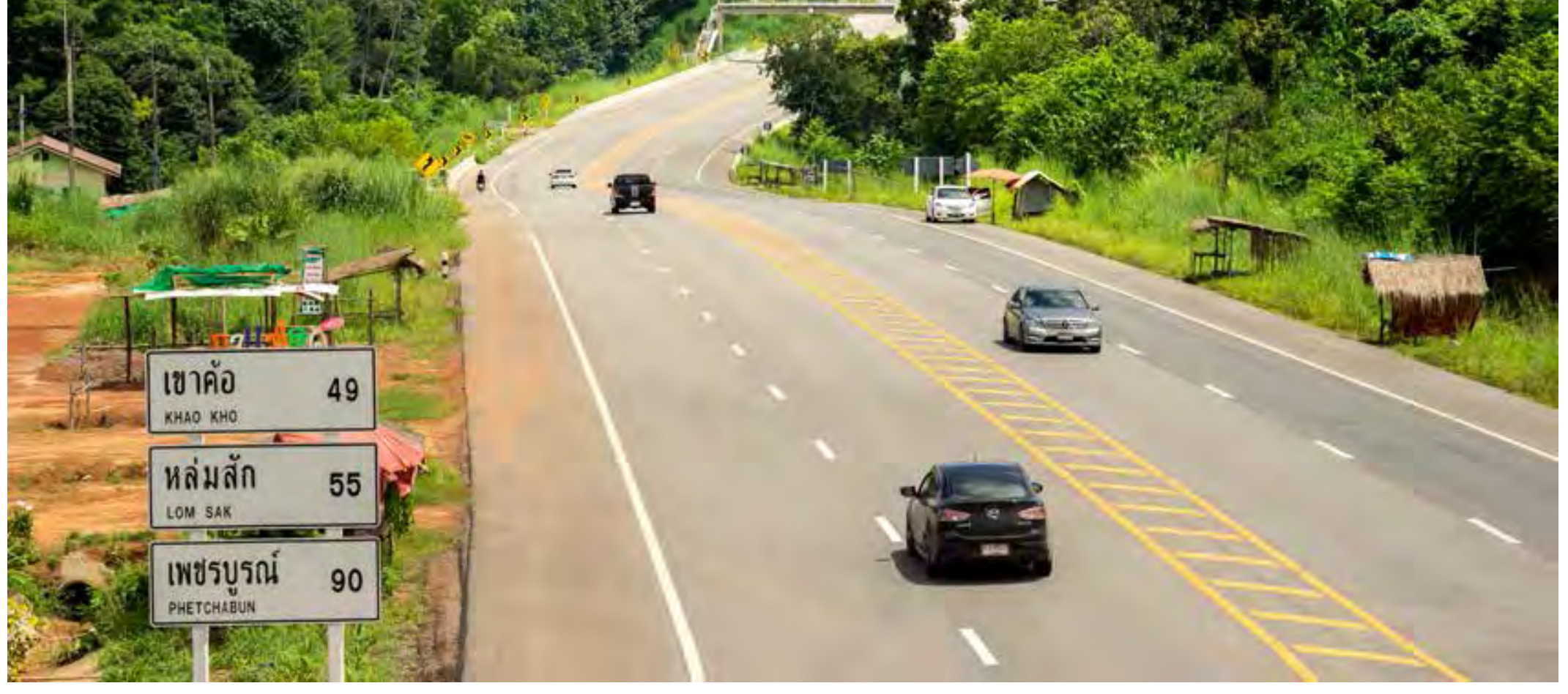

Infrastructure

Road Systems

ADB's CPS for Thailand places a heavy emphasis on both infrastructure development and the facilitation of private sector involvement in sectors of the economy where the state has historically played a dominant role. Lending for infrastructure projects has been a core focus of ADB activities in Thailand since the early 1970s. While new borrowing for infrastructure in Thailand has been relatively limited since the establishment of ADB's TRM on account of domestic market liquidity, ADB continues to make a major contribution to the improvement of the country's road and rail systems, and the facilitation of private sector involvement in infrastructure investment.

As a result of considerable investment over the last 30 years or so, Thailand has built up a comprehensive system of good quality two- and four-lane highways and paved provincial roads. In pursuit of enhanced economic efficiency and competitiveness, and associated social gains, further improvements in the road system continue to be a high-priority policy. The DOH has identified intercity motorways, Bangkok express ring roads, industrial ring roads, four-lane highway widening, and for the rod sysen ADBing countries as its strategic priorities for the road system. ADB's strategy is to assist the Ministry of Transport in this regard. 
Box 8: Greater Mekong Subregion Highway Expansion Projects

Considerable ADB investment has been directed toward highway expansion, which serves the dual purpose of facilitating the movement of people and goods within the domestic market, while contributing to enhanced connectivity and economic linkages with neighboring countries within the Greater Mekong Subregion. Several stretches of highways in northern, northeastern, and central Thailand have been upgraded to the four-lane divided highway standard as part of the various economic corridors, which connect these regions to neighborin countries (see Section IV). Two additional projects will be discussed briefly here, as they represent the only two loans for infrastructure that the Government of Thailand has taken out since the inception of ADB's TRM. In December 2009, a loan of $\$ 771$ million was approved by ADB for the upgrading of 178 $\mathrm{km}$ of existing two-lane national highways to four-lane divided Source: Asian Development Bank.

ADB has also contributed two TA projects for intercity motorways projects, including an in-depth analysis of the potential for PPP in motorway investment. This analysis led to the cabinet approval for a PPP-financed motorway connection from Bang Yai to Kanchanaburi in western Thailand, as part of the economic corrido linking the Dawai deep sea port in Myanmar. standard: Highway 12 between Phitsanulok and Lom Sak $(105 \mathrm{~km})$, which forms part of the GMS East-West Economic Corridor; and Highway 359 from Phanom Sarakham to Sa Kaeo, which makes up part of the GMS Southern Economic Corridor. The Government of Thailand contributed an additional \$102.3 million to this project, the construction of which was completed in mid-2016. The project was completed ahead of schedule, under budget, and in full compliance with all ADB guidelines. A highly favorable performance evaluation, together with a tried-and-tested infrastructure investment model, contributed to the in-principle approval by the cabinet on 18 October 2016 of a further B6.8 billion highway improvement project in the northeast region, on Highway 22 from Udon Thani to Sakhon Nakhon, and then to Nakhon Phanom, and on Highway 23 from Roi-et to Yasothon. ADB's lending process is under way and is expected to obtain approval by 2017, with construction commencing by 2018. Lending for infrastructure projects has been a core focus of ADB activities in Thailand since the early 1970 s. ADB continues to make a major contribution the improvement of the country's road and rail systems, and the facilitation of private sector involvement in infrastructure investment.

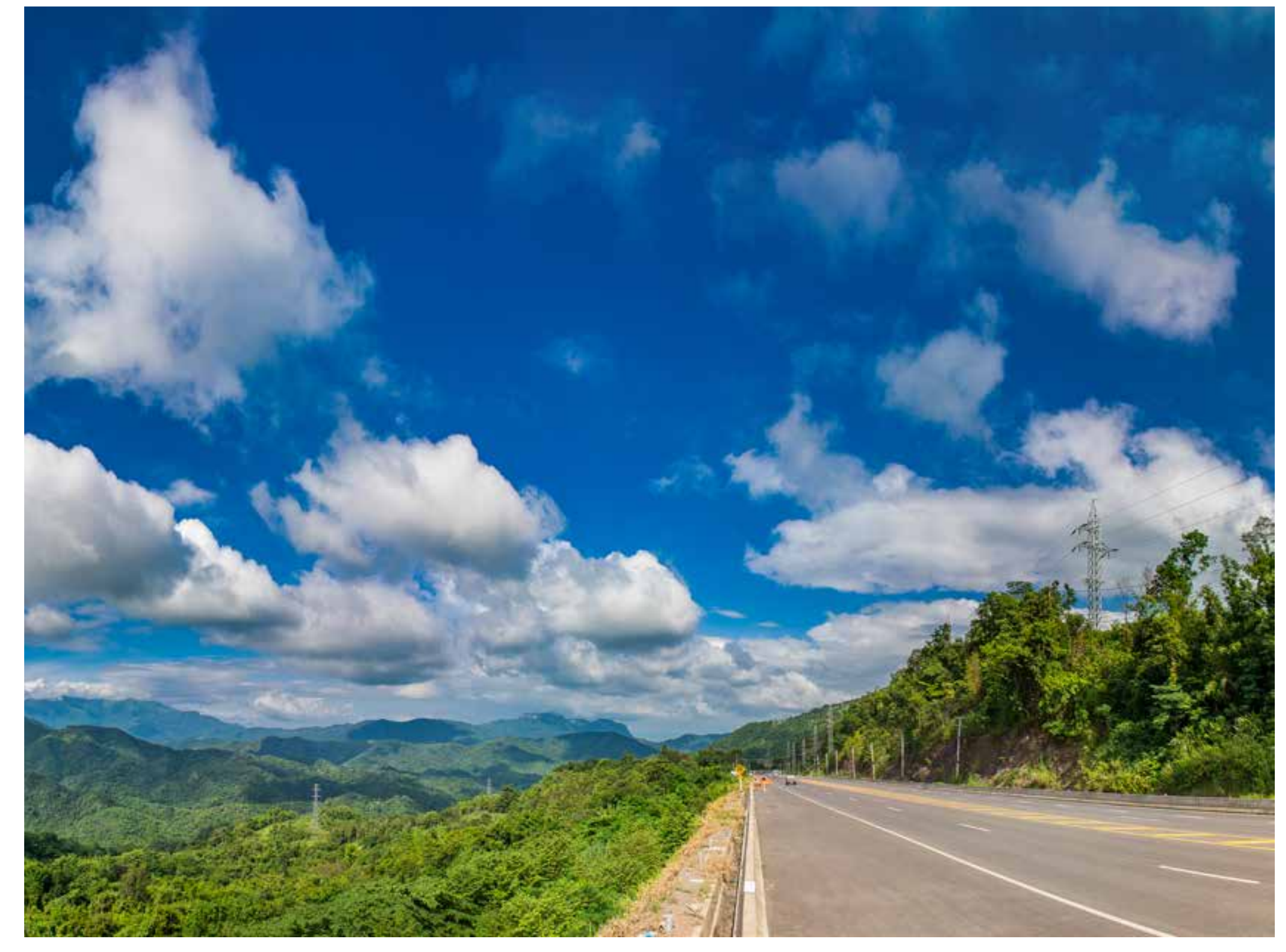




\section{Rail Systems}

ADB has been providing technical support to the development and improvement of two rail systems in Thailand: the mass rapid transit system (MRTS) in Bangkok, and the State Railway of Thailand (SRT)

\section{State Railway of Thailand}

The mainline railway system in Thailand makes an important contribution to help the government achieve several of its sustainable development goals. It has the potential to boost competitiveness by reducing both the temporal and financial costs of in-country transport, particularly relating to import and export trade. It can also be a crucial cog in subregional trading systems. Historically the subsidized railways have been means of domestic transport for lower-income groups, thus helping to alleviste povety and foclltawe economic ery mobility. By taking freight transport off the roads, the railways may also help reduce pollution and congestion. Heavy investment in the road system over the last 30 years has been paralleled by a decline in much-needed investment in the railways, leading to a shift from mallo road feight The ral system is in despeate need of investment in track, locomotives, and rolling stock, and also has a very poor safety record. The SRT has to address urgently its debt burden, which in 2012 stood at B100 billion ( $\$ 3.2$ billion),

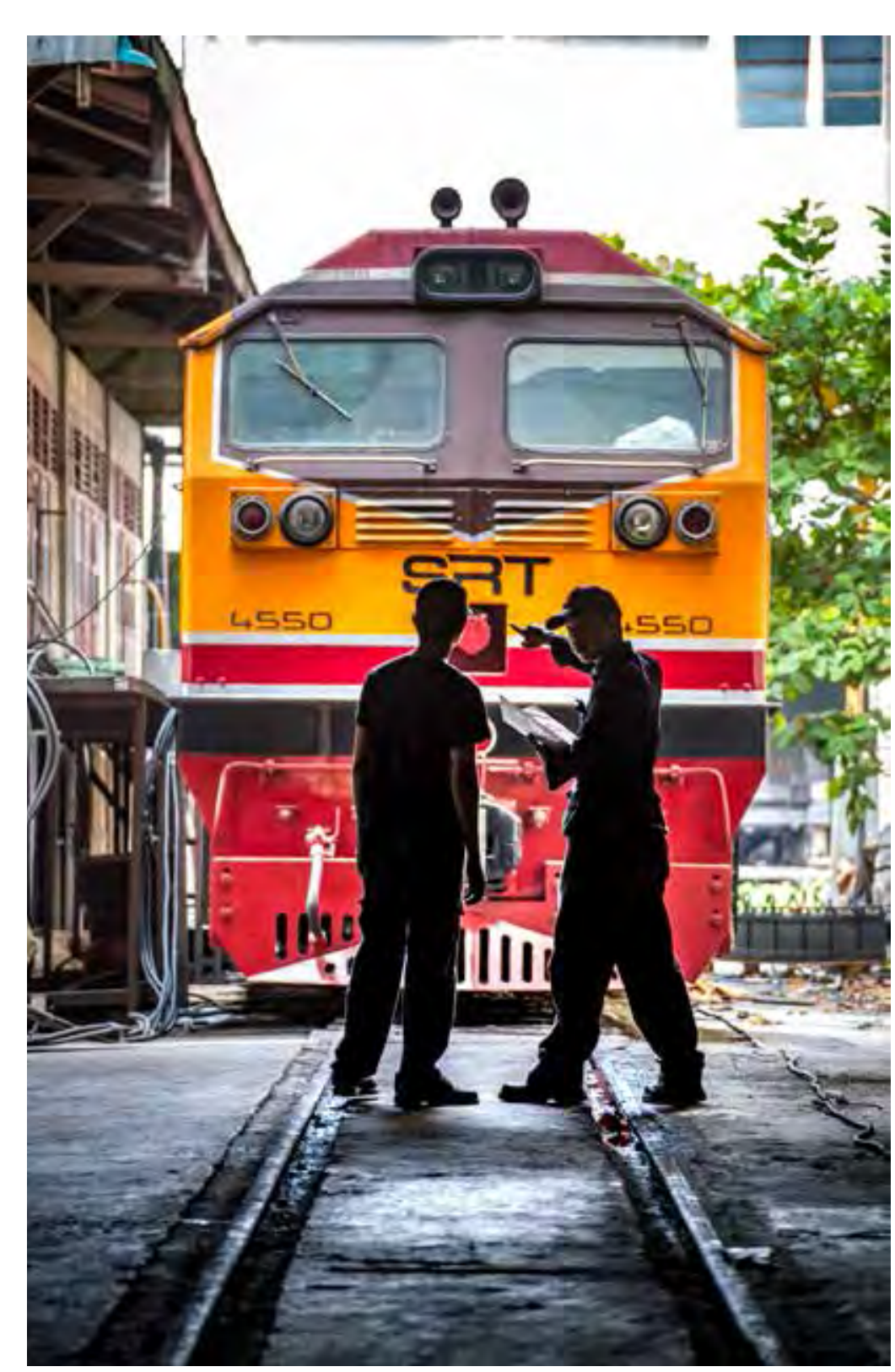

and an annual operating loss of B10 billion in 2008 (the most restructuring, investment, and modernization.

ADB was asked by the the government to help pave the way for of the state-run railway system to underpin the institution's immediate survival and strengthen it for the longerterm by improving its operational performance. An initial TA collected and collated background information and stakeholder opinion, conducted a situation analysis, and delineated a policy matrix and restructuring program. To help the government dreft Railway Policy Statement which se objectives, including recapitalization, infrastructure recovery, and safety improvement to raise public confidence in the future of the Thai railway system. The government then requested a follow-up capacity d system. Specifically, the project explored how the quality of the ailway system, especially third class travel, could be improved without pricing low-income groups out of the market. ADB helped the government formulate a new passenger service strategy and first prionity is public safery, wh the establishment of a safey task force and an immediate safety audit. The second was the establishment of a project management organization to manage some 20 major capital investment projects which lay at the heart of crucial infrastructure improvements. Other priorities include blic to build a more positive image of the railway system as the reforms progress. As a follow-up, the government also requested further TA to help strengthen the SRT's operational performance by designing and helping to implement a comprehensive financial manasement accounting of the SRT's financial performance, but also to enable its management to undertake strategic planning, operational decision making, and service monitoring and evaluation.

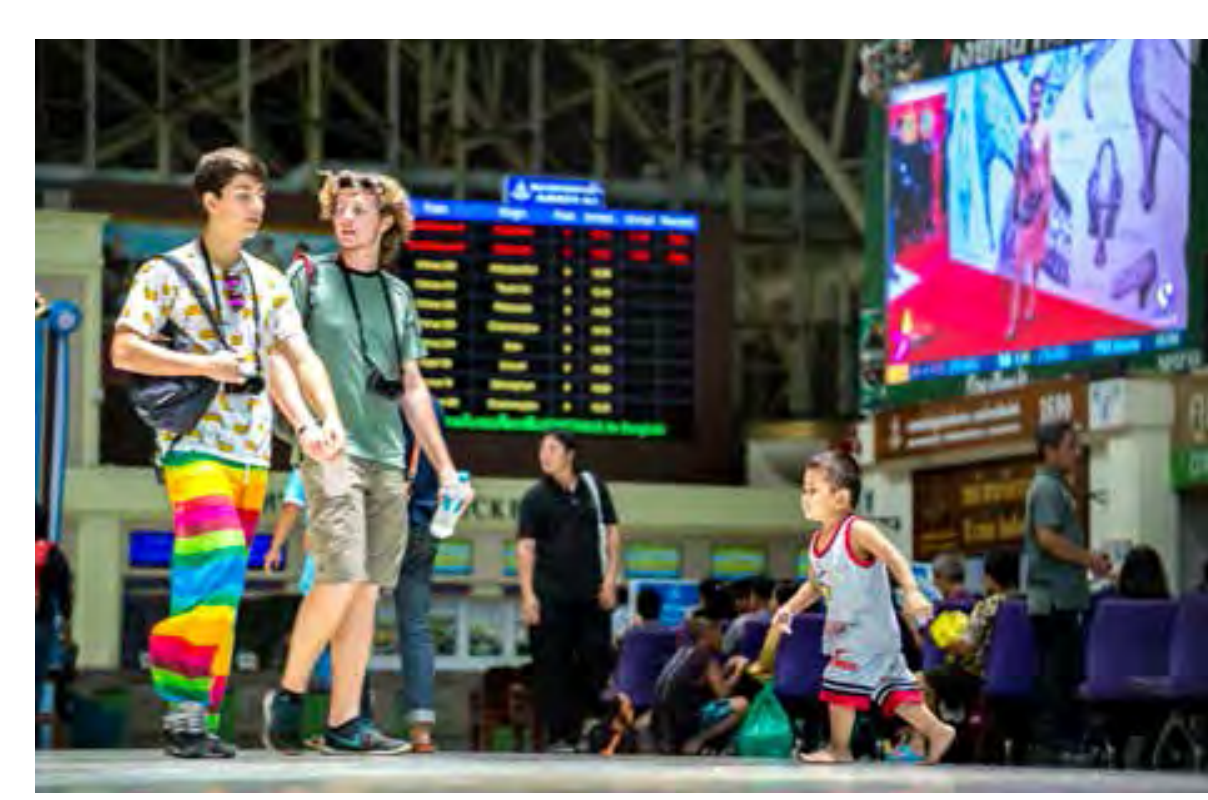


The MRTS is one of several sectors under infrastructure development where ADB has beenhelping the governmentexplore the potential for PPP as an investment model, which accelerates infrastructure development while reducing the demands it makes on the public purse. During 2010, PPP was a relatively new concept in the Thai context, and thus ADB has provided three TA projects to help the government improve its capacity to oversee infrastructure investment using the PPP model. This included the revision of legislation governing the review and approval of PPPs, which was promulgated in 1992 in the form of the Act on Private Participation in State Undertakings. The legislation on PPPs needed to be updated to accommodate and guide prospective private sector involvement in the MRTS, as well as other forms of infrastructure. The government had encountered problems in the clear definition of PPP, and the 1992 law lacked concrete evaluation criteria for the assessment of PPP projects. There was also a lack of clear procedures for the allocation of risks between public and private partners, and of provision for government intervention in the public interest should circumstances dictate. ADB was asked to assist a Ministry of Finance PPP task force in devising an enabling PPP framework in support of its medium-term infrastructure development program, as well as helping to identify priority projects and strengthen institutional capacity. The AD TA defined the legal procedures and institutional mechanism for drafting new legislation concerning the structuring, financing, the health sector and, together with the Ministry of Education, strengthen capacity to procure, manage, and monitor social sector PPPs. In the health sector, Thailand faces significant future challenges in seeking to bridge the health service gap between rural and urban areas, catering to the health and welfare needs of an aging population, and keeping up with technological and organizational advancements in health care. Such infrastructure requires substantial investment, and thus the MOPH has been keen to explore ways of attracting more private sector involvement in the public health service, such as through PPP. However, the in the public health service, such as through PPP. However, the and manage PPP health projects. ADB's TA helped by undertaking a sectorwide diagnostic analysis, reviewing policy provisions that are relevant to PPP, and identifying potential projects for PPP in are services; haemodialysis; advanced imaging radiological services; development of new hospital facilities and infrastructure; and cardiac, cancer, and geriatric medical services. The TA helped to improve the overall understanding and prerequisites of PPP schemes and business opportunities at the MOPH and helped establish institutional procedures for identifying and assessing potential PPP opportunities. Lessons learned from the analysis of PPP potential and constraints in the health sector are being applied, through further TA, in the form of a pilot scoping study for project structuring. The next phase is to develop a long-term master plan for PPP in the health sector.
Finance Sector

ADB has been supporting the development of the finance sector in Thailand since ADB's inception in 1966, and this continues as a high priority in $A D B$ 's current $C P S$. There are two key and related strands to the work of ADB's TRM in this regard: the development of Thailand's capital markets and financial inclusion

\section{Capital Markets Development Program}

Following on from the work ADB undertook on financial markets reform in the immediate aftermath of the 1997 financial crisis, ADB returned to support capital market development in Thailand through a series of TA projects and, subsequently, in February 2011, with a program loan of $\$ 300$ million. The Capital Market Development Program was designed to contribute to the implenention of the governents Capial Marke Development Master Plan, which ran from 2009 to 2013, and which included such objectives as liberalizing the securities business, demutualization of the stock exchange, streamlining the tax system relating to financial products, developing the domestic bond market, and legal reform. The program was partly a response to the effects of the global financial crisis in 2007-2009, which had reduced the value of the Thai stock market by about 50\% and revealed the insufficient capacity of domestic capital markets to finance much-needed investments in the public and private 


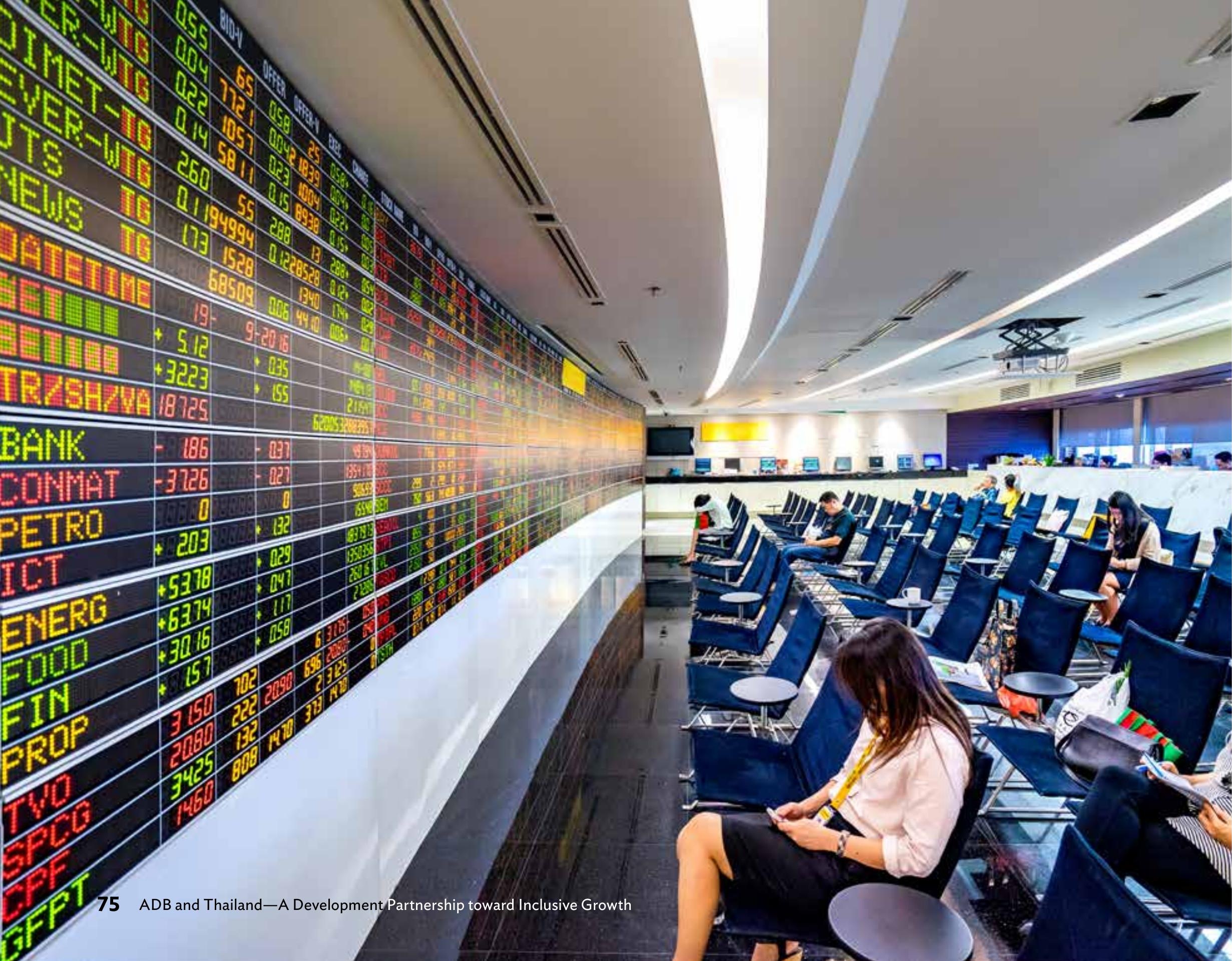

sectors. The government wished to make the country's capital markets more resilient in the face of external shocks by improving coordination between regulatory agencies, promoting greater transparency in the capital market sector, and strengthenin linkages with regional capital markets.

The Capital Markets Development Program was accompanied by a TA designed to help Thailand develop an internationally competitive capital market through attracting and generating secure and diverse funding sources, which could help contribute to the country's domestic investment needs. The TA involved PDMO to impove its capaciy for estalishing and op onlending, and to develop a framework for guarantees to stateowned enterprises. The TA helped the Secondary Mortgage Corporation to evaluate the mechanisms for the future positioning, shareholding, organizational structure, and market

ADB has been supporting the development of the finance sector in Thailand since ADB's inception in 1966, and this continues to be a high priority in ADB's current CPS. The key areas include Thailand's capital development of Thailand's capital markets and financial inclusion. products for underpinning the viability and sustainability of its operations. ADB also provided advise to the Securities and companies Advice was also given to the SET in the development of a road map for the Capital Market Development Fund, and the Bank of Thailand to improve exchange control policy. A study on a mortgage insurance scheme to protect lenders against loss caused by bo Office (FPO). All reform actions under the Capisal Markets Development Program were successfully implemented. Having thereby helped improve the regulatory infrastructure at the top of the finance sector pyramid, and with the middle segmentsattention then the pyramid, focusing on the pressing issue of financial inclusion.

\section{Financial Inclusion}

The government approached ADB to provide assistance with improving financial inclusion following the publication of the Global Microscope survey of the microfinance business environment. Thailand placed last out of 55 surveyed countries with a regulatory frameworkscore for financial inclusion of 21.2/100 (compared with Cambodia which scored 87.5/100) (Economis Intelligence Unit, 2009). To comprehend the Financial Institution 
(FI) landscape in Thailand, ADB did a preliminary study, published as an ADB Working Paper (Bird, Hattel, Sasaki, and Attapich, 2011). ADB was then asked to help the government devise National Strategy for Financial Inclusion. Financial inclusion is a development strategy that aims to ensure that everyone who wants and needs to can have access to affordable, appropriate, and dependable financial services.

Attempts to foster financial inclusion in Thailand actually predate the concept's emergence as a central development objective around the year 2003. These early efforts provide an and promising potential foundation for building Fl. Government Savings Bank (GSB) was established in 1949, based upon the Savings Office created by King Vajiravudh in 1913. The country's largest credit and savings specialized financial institution (SFI), the BAAC, which mainly benefits the rural population, came into being in 1966. Following the problems people experienced in the aftermath of the 1997 Asian financial crisis, the government introduced two schemes, which principally targeted lower-income groups. The National Village and Urban Community Fund (more popularly referred to as the Village Fund) allocated a B1 million seed fund to each of Thailand's 75,000 villares and 4,500 urban communities to be used to finance rotating credit and savings associations, and support local social sevices. The 8 also introduced a universal health coverage scheme, which guaranteed all Thai citizens access to a basic minimum of health

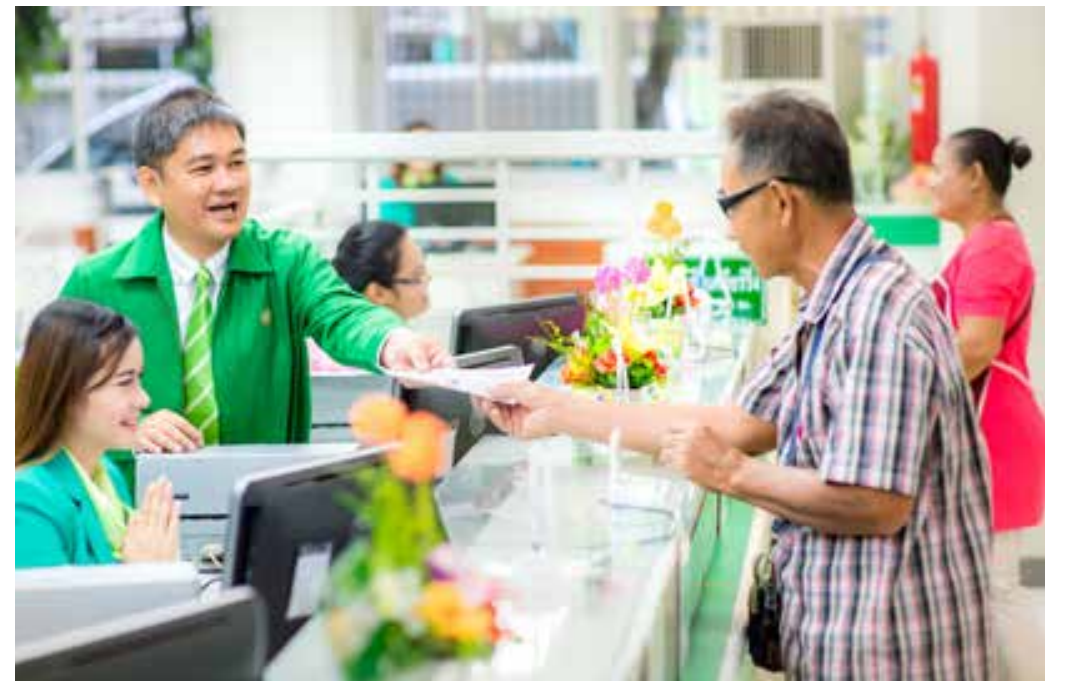

contrast, commercial banks have had much less involvement with low-income groups, despite government attempts to facilitate banks' expansion into this segment of the population. Accordingly, rural areas in particular have to rely on a wide variety of informal and semiformal institutions to borrow money for productive investment, for their savings, and for making financial transfers (e.g., receiving remittances). Despite their importance to lowincome rural people, the informal finance sector only accounts for approximately $0.3 \%$ of Thailand's total credit volume, and the semiformal sector only an additional $7 \%$. Based on the evidence presented in an ADB TA report the authors reco a joined-up strategic approach that feeds financial inclusion as a policy objective into all segments of the finance sector, from formal to informal, government to commercial, through regulatory fuence and financial incentive. Commercial considerations lone will not readily change the status quo, but innovative new products and imaginative new technologies, such as a mobile ne e-money platform, can start to reduce the gap between need and supply for those the formal finance sector has largely bypassed. Orchestrated effectively, microfinance can function as a development tool by promoting and facilitating savings and intelligent consumption.

With regard to insurance, the first challenge is to change the surance culture in Thailand to help the many millions of uninsured people to recognize the value of taking out cover for illness, disability, unemployment, retirement, accident, or death. This may require better financial education to draw lowincome people in particular away from informal systems of social protection, which may not be robust enough to cope with

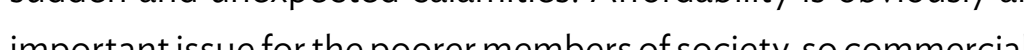
community, and public sector insurance products and schemes should be designed to suit people's ability to pay. In Thailand of the 18 million or so policies which are supported by a variety of formal and informal risk carriers, only sor

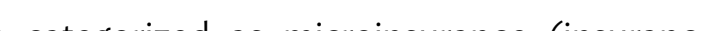
products for low-income groups specifically tailored to their particular needs and circumstances). The commercial secto is almost completely absent from this segment of the market, 
in part because the financial returns on very low premiums are unattractive, but also because the government already has a strong presence in social protection at the local level through its universal coverage schemes, even though these do not insure all forms of risk. Thus, to achieve inclusive insurance, there is a need for much more product development and regulatory attention to be given to the microinsurance segment of the market. While more imagination and commi designing inst there is already in place a distribution network-post offices, community-based organizations, cooperatives, credit unions, mobile network operators, and even retailing outlets-through which microinsurance cover and product information might be disseminated. The Office of be dissem formal insurance companies to help them develop and promote microinsurance products: there are hundreds of thousands of insurance agents in Thailand, but less than 1,000 deal with microinsurance.

The study also looked at the regulatory framework for the micro segment of the financial market, and found that the main impediment to the commercial banks' greater involvement in the microfinance sector appears to be that, since their recovery from the financial crisis, they have been doing quite well out of the status quo. When the Bank of Thailand introduced Microfinance Guidelines in 2011, few commercial banks demonstrated much interest in or commitment to downscaling their operations to deliver more microfinance to lower-income groups. In general, the risks and costs of extending services to poorer citizens are insufficiently attractive for the banks to play a leading role in financial inclusion from market incentives alone. One recommendation was to create a new licensing and supervision regime for microfinance, tiered to accommodate deposit-taking, credit-only, and small informal institutions. In an open market, regulatory coercion is not feasible, but facilitating the banks' greater involvement at the grassroots level by supporting the use of modern mechanisms such as mobile phone banking may help to raise participation through improving accessibility.

SFls have been much more active in making small-scale finance accessible to poorer and more remote communities, partly because historically they have had a longer presence here, and partly because they have experimented with tailored savings products, and outreach connectivity with community groups. These SFIs are not exposed to the same level of financial risk as the commercial banks, as some of theirlosses may be covered from the state budget although historically this has rarely been necessary. They are not subject to the same level of regulatory supervision as commercial banks, and their repayment perfor as com in the segment of the market that they serve. Semi-formal and informal Fls, by their nature, have tended to be closer to the income groups that are targeted by financial inclusion policy and, as such,

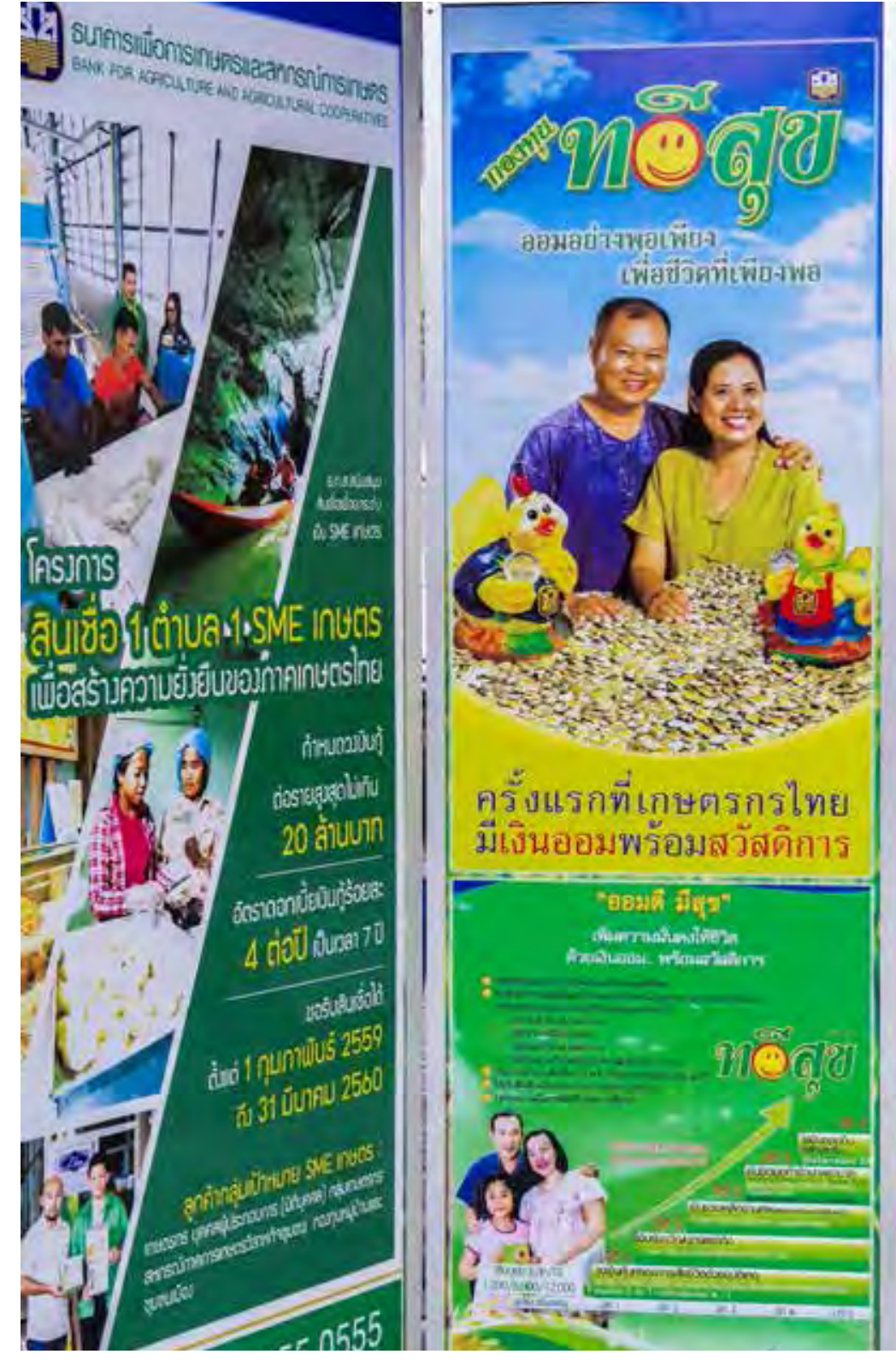

ADECADE OF PARTNERSHIPTHROUGH THAILAND RESIDENT MISSION 
continue to play a very important role. But regulatory oversightis often lax, and needs to be improved. Another challenge for the future will be to find a way to formalize these informal institutions without stifling the actual and potential role they play in financia inclusion

The most significant consumer protection issue facing lowerincome groups is indebtedness, which is a serious impediment to economic and social progress. According to the 2013 FinScope study, $62 \%$ of farmers are in debt, making them the most indebted occupational group in Thailand. Indebtedness is, in turn, often inked to recklesslending, Inked torecklesslending, wher. this besting subservient to the financial interests of private lenders. There are presently insufficient regulatory checks and balances which oblige lenders, particularly nonbank financial institutions, to undertake thorough checks of customers' debt liabilities and their repayment capability, and this may be compounded by poorer clients' lack of financial literacy and their ability to evaluate the risks attached to availing themselves of seemingly cheap credit. Lenders may secure their loans against the client's assets, but their ability to repay may nonetheless be constrained, meaning that they are at risk of losing their assets and ending up worse off than before taking out a loan Informal lenders can be quite unscrupulous in this regard, and many poorer people in the peripheral provinces may be trapped in a perpetual debt cycle, borrowing more simply to service existing debts. Over-lending to high-risk clients is also not sound business for the finance industry, but the denial of loans

81 ADB and Thailand-A Development Partnership toward Inclusive Growth internationally. The survey identified 25 financial education programs in operation in Thailand across a range of bodies. The level of provision was patchy across regional and among different demographic and social groups, and coordination or synergy between the programs was limited. Specialized financial institutions such as the Bank for Agriculture and Agricultural Cooperatives and the Government Savings Bank had both quite long-established financial education programs (e.g. "smart farmer," "debt doctor," and "sufficiency economy (e.g. "smart farmer," "debt doctor," and "sufficiency economy
learning centers") and a wide national reach through their local learning centers") and a wide national reach through their local branches and in-school activities. Commercial banks recognized the value of financial literacy, particularly among low-income education programs. The Stock Exchange of Thailand has a schools-based financial education program, reaching out to 7 million students who might be potential future investors. An array of financial literacy material is available through the mass media via newspaper columns, radio programs, TV channels, websites, and Facebook, although these may not readily reach all lower-income groups in all lower-income groups in the more renote areas. Among the most widespread financial education provision targeted specifically at low-income households is that provided to local communities by civil society and community organizations, nongovernment organizations, and even development monks in

Buddhist temples Asian Dinclusion in the nation's financial system. In 2013, the Asian Development Bank (ADB) conducted a su demand, supply, and impact of financial education s Thailand, and made policy and operational recommendations
based on promising models identified locally, nationally, and

ements: microfinance supply side, microinsurance, qualitative demand side, microfinance regulation, consumer protection, and financial literacy. 
ADB recommended the establishment of an oversight mechanism to draw all financial education provision ac a variety of framework It also sugsested that a Finuncial Inclusion Innovation Fund be established to encourage both private and public sector organizations to develop new, imaginative, relevant, and targeted financial literacy programs.

Source: Asian Development Bank.

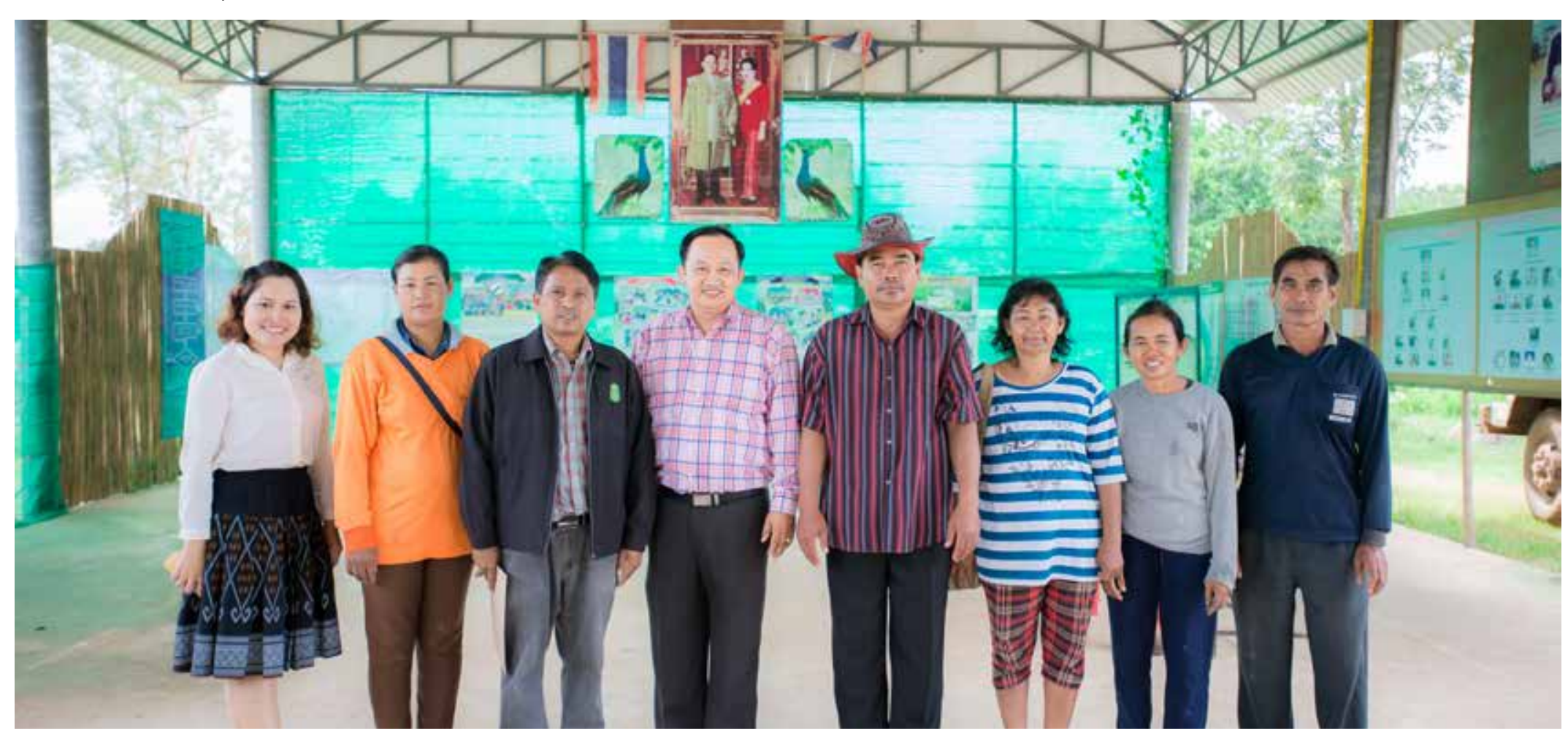

83 ADB and Thailand-A Development Partnership toward Inclusive Growt
In 2015, ADB in coordination with the Bank of Thailand and the Organisation for Economic Co-operation and Development Measure Financial Literacy and Financial Inclusion. The OECD is in the process of publishing a cross-country analysis report. Based on the country results of the survey, ADB is presently working with the Bank of Thaland to advance nation financial literacy in a coordinated and targeted manner.
Thailand is in an unusual situation in that the private sector has relatively limited involvement in the microfinance sector. This is not necessarily a bad thing, given that the government-led program presently functions quite well. The BAAC and GSB are able to offer competitive rates of interest without being a burden to the government, relying largely on their own resources. These SFls, together with community-based financial intitutions, play a vitally important role in helping the very poor, and may also provide conduit for these people to gain access to formal private financia institutions in the longer term. However, they lack the standards of prudential regulation that are applied to other segments of the finance sector, and this is an area that requires priority attention. $A D B$ is currently involved in a $T A$, which is seeking to strengthen specialized and semiformal financial institutions in order to support financial inclusion.

ADB has been at the forefront of efforts to help the Government of Thailand improve the people's access to quality and appropriate financial services and products. One further and very importan component of financial inclusion in Thailand that ADB is currently engaging in is reform to the country's pension system. $A D B$ undertook a TA for the FPO on pension system design in 2002, which helped to outline a framework for mandatory pension contributions (Pillar 2) to supplement the Old Age Pension (Pillar 1) which only replaces $35 \%$ of average pay for pensions, which is considered inadequate. The TA contributed to the design of a reformed pension system that is institutionally sound, socially adequate, and financially sustainable, providing maximum social protection at least cost to budgetary resources. Reform to the pension system is also directly linked to capital market development: a healthy capital market requires large institutiona investors, including pension funds. ADB will continue to work with the FPO on broadening and strengthening the pension system in Thailand.

\section{Regional Cooperation and Integration}

$\mathrm{RCl}$ is one of ADB's three critical strategic agendas (alongside inclusive economic growth and environmentally sustainable growth), and five core specializations (alongside infrastructure, environment, finance sector development, and education), as identified in ADB's Strategy 2020,5 and reaffirmed in the MidTerm Review of for both by providing a stimulus for countries which have not yet progressed to middle-income status, and by extending market and investment opportunities for those that have. As such, it has sharing knowledge and best-practice cross-regionally, it may also 5 ADB. 2008. Strategy 2020: The Long-Term Strategic Framework of the Asian
Development Bank, 2008-2020. Manila.

ADB. 2014. Midterm Review of Strategy
Transforming Asia and Pacific. Manila. 
elp to improve standards of governance, access to technology, and share the most effective modalities of sustainability.

In the Southeast Asian context, regional integration is a process that has been gaining in substance and momentum since the late 1960s. The Association of Southeast Asian Nations (ASEAN) formed in 1967 is a region bloc of 10 nations (WTh Tinor-Leste cooperation. An intraregional ASEAN Free Trade Area was established in 1992, and ASEAN also has free trade agreements with the PRC, the Republic of Korea, and Japan. In 2015, the Community, which represents perhaps the pinnacle of attemp at regional integration over almost 50 years. The ASEAN Economic Community aspires to become a single market and production base allowing the free movement of goods, services, and investments, and freer flows of capital and skills. growth triangles. Governments came to recognize the advantages of cooperation over competition, and specialization over duplication, and have thus come to embrace the virtues of overer cooperation and integration at the subresional level ADB has played a leading role in subregional cooperation, and also in helping to strengthen ASEAN integration by linking the various subregional cooperation initiatives. Its flagship strategy, as far as Thailand is concerned, has to foster greater integration in mainland Southeast Asia through its GMS Economic Cooperation Program which was initiated in 1992 . Thailand is also an integral part of the which wintion 1902 Triangle, formed in 1993, and the Bay of Bengal Initiative on Multi-Sectoral Technical and Economic Cooperation, formed in 1997.

The key objectives of the GMS Economic

Cooperation Program are connectivity,

competitiveness, and community.

85 ADB and Thalland $-A$ Development Partnership toward Inclusive Growth
Box 10: Greater Mekong Subregion

The Greater Mekong Subregion (GMS) program has brought together the six countries that border the great Mekong River (in the People's Republic of China, specifically the provinces of Yunnan and Guanxi) which, since the 1980s, has been visualized as a powerful symbol of cooperation and shared purpose. The key objectives are connectivity, competitiveness, and community. The Asian Development Bank (ADB) hosts the Secretariat of the GMS. Since 1992, ADB has invested approximately \$63 billion in essential infrastructure projects, which not only facilitate the economic development of individual GMS states but also help to realize the objective of strengthening subregional integration. Under its Regional Investment Framework, which operationalizes the GMS Economic Program Strategic Framework, ADB plans to invest a further $\$ 51.3$ billion in the subregion between 2012 2022, mainly in the transport sector (86\%), and an additional $\$ 760$ million in technical assistance, mainly in information and communication technology (29.2\%) and the environment (21.9\%)

There are multiple prongs to ADB's GMS Economic Cooperation Program. The principal strategic focus has been on improving

ADB. 2014. Midterm Review of Strategy 2020: Meeting the Challenges of a Transforming Asia and Pacific. Manila

Source: Asian Development Bank. transport infrastructure to facilitate intraregional trade, tourism and other forms of connectivity. There are three principal transport corridors: north-south, east-west, and southern, with additional connections between these. ADB's energy strategy is improving regional energy cooperation and security, and developing low-carbon and renewable domestic energy resources. The Core Agricultural Support Program is supporting climate-friendly agricultural production and agribusiness, food safety, modernizing agricultural trade, agriculture for clean with environmental protection, biodiversity conservation, and climate change mitigation. There are also programs for urban development, the promotion of the GMS as a single tourism destination; enhanced telecommunication and information and communication technology connectivity; and human resource development for health, education, labor force, and social advancement. In line with the 2014 Midterm Review of ADB's Strategy 2020, attention is now focusing on the software or the second phase of regional cooperation and integration, such as trade facilitation and harmonization, investment climate improvement, and the development of border economic zones to build transport systems into fully fledged economic corridors. 
Thailand has been ADB's main external development partner for RCl initiatives and, due to its strategic location, is a pivotal player in ADB's GMS Economic Cooperation Program. The GMS Environment Operations Center is hosted by ADB's TRM in Bangkok, while some ADB staff working on the GMS cooperation program have been outposted to ADB's TRM. Thailand is an important economic hub for the GMS, and enjoys synergies with its neighbors both as a market for their produce and as a source of technology, capital, and expertise. RCI has also been an importan priority area of the Government of Thailand since the late 1980s. Emerging economic corridors connected by a myriad of transregional road networks mean that Thailand's borders are now key nodal points in integrated trade and communication systems Thailand's lagging resions. ADB's current CPS ad tis strategic geographic suberic position. First, it is supporting the government's subregional economic cooperation efforts in respect of integrating production, distribution, and service chains; reducing barriers to regional trade and investment; improving transport and energy

ADB's current CPS adopts a two-track approach to help Thailand capitalize on its strategic geographic and economic position. veloping economic corridors; integrating capita militating labor migration. Second, ADB is supporting Thailand's efforts to expand its role as a development partner through sharing its experience and knowledge across the region. The important aspects of Thailand-GMS cooperation since the formation of ADB's TRM will be focused in this chapter as a lens on ADBThailand RCl initiatives.

ADB-Thailand Partnership in the Subregional Economic Cooperation Program

The transport sector has historically been one of the most important areas of ADB involvement in the GMS since the 1990s, with roads acting as the principal sinews of regional connectivity. In 1995 , ADB dew ADB dew up a Transport Master Plan capital investment. Three years later, the plan was broadened to incorporate the concept of economic corridors as a means of facilitating integrated forms of development, trade, production, and welfare improvenent between economic hubs. Through and welfare in ports, and hitherto isolated areas can be connected to regional markets and value-chains. ADB has been supporting the six member states of the GMS to develop three principal economic corridors: East-West, connecting Viet Nam, the Lao PDR,

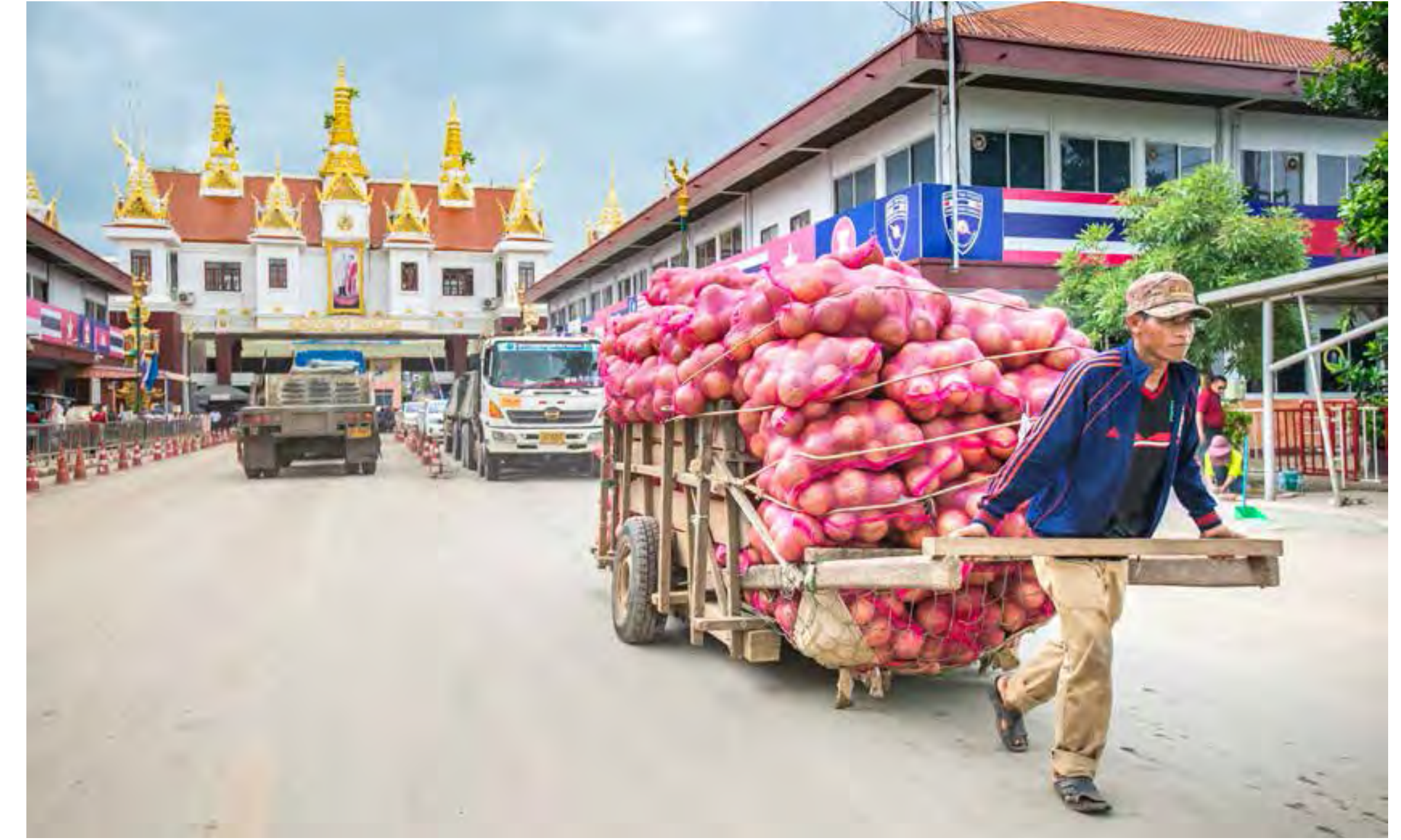

Thailand has been ADB's main external development partner for $\mathrm{RCl}$ initiatives and, due to its strategic location, is a pivotal player in ADB's GMS Economic Cooperation Program. 


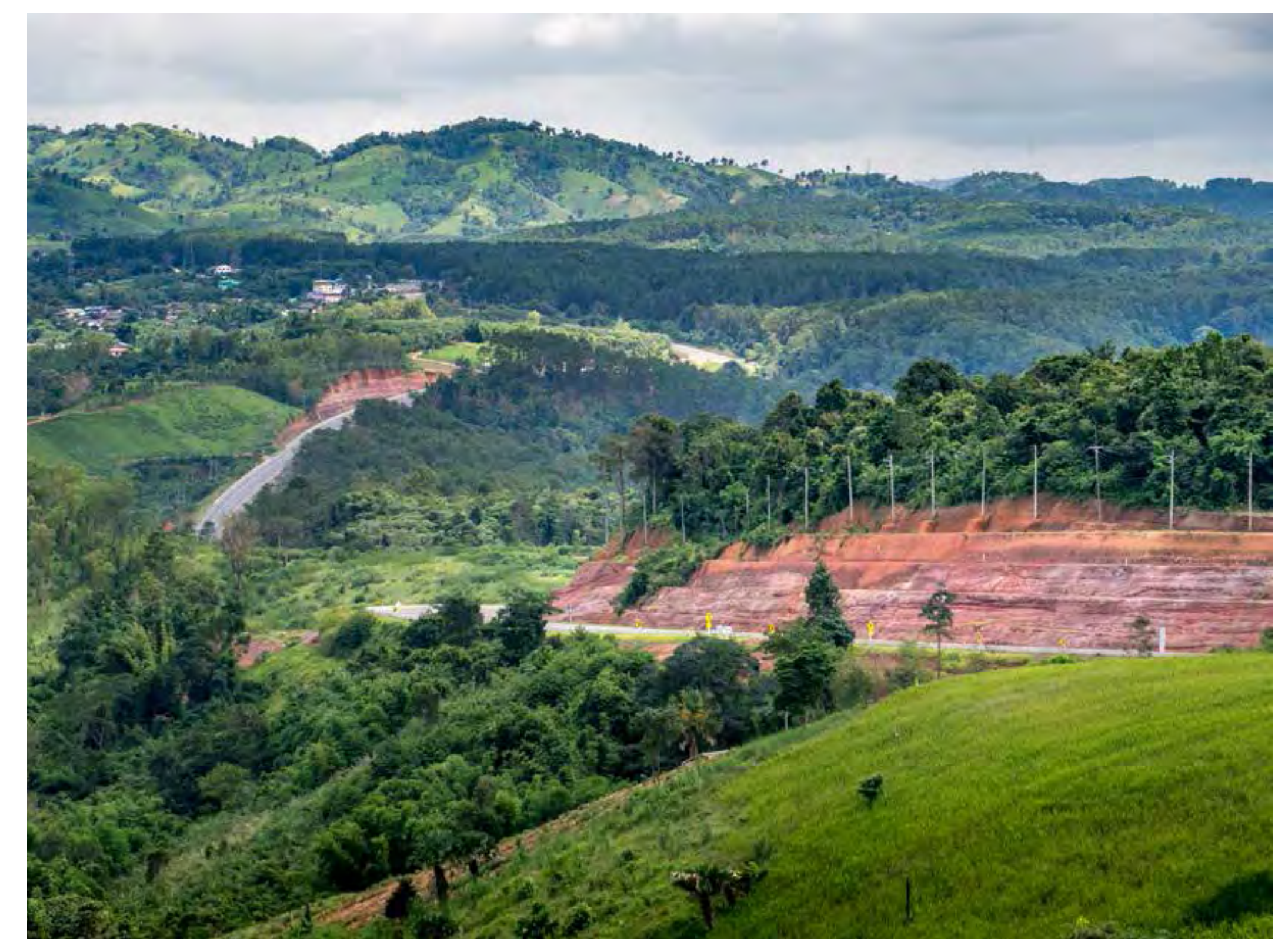

Thailand, and Myanmar; North-South, connecting Yunnan with Bangkok via the Lao PDR and Myanmar, and also Viet $\mathrm{Nam}$; and a Southern Economic Corridor connecting Thailand, Cambodia, and Viet Nam. There are also six interwoven branch corridors. In 2004, ADB undertook a GMS Transport Sector Strategy Study to identify the necessary strategic underpinnings for building an integrated multimodal transport network in the GMS during the period 2005-2016, which included 32 high-priont projects.

Thailand is pivotal to six of the GMS economic corridorseast-west, north-south, southern, northeastern, central, and southern coastal-and substantial ADB support has been targeted at improving Thailand's domestic highway system to facilitate transport connectivity with neighboring countries. Even before the establishment of ADB's TRM, ADB investmen in various high Chastern, and eastern Thailand, which have subsequently become key parts of the economic corridors system. Additionally, a 1997 border towns development project helped to improve urban infrastructure in towns that are now the focal points of trade connectivity between Thailand and its neighboring countries. ADB's $\$ 77$ million financial support for upgrades of Thailand's highway system along the SEC leading to the the Aranyaprathet-Poipet border with Cambodia, and the East-West Economic Corridor linking Thailand with the Lao PDR at the Mukdahan-Savannakhet border on the Mekong River. The Bang Yai-Nakhon Pathom-Kanchanaburi intercity motorway project, for which $A D B$ has provided $T A$, is an important additional project, for wich ADB has providedTA, is an mortant additiona segment of the SEC leading to the border with Myanmar and the deep-sea port at Dawa.
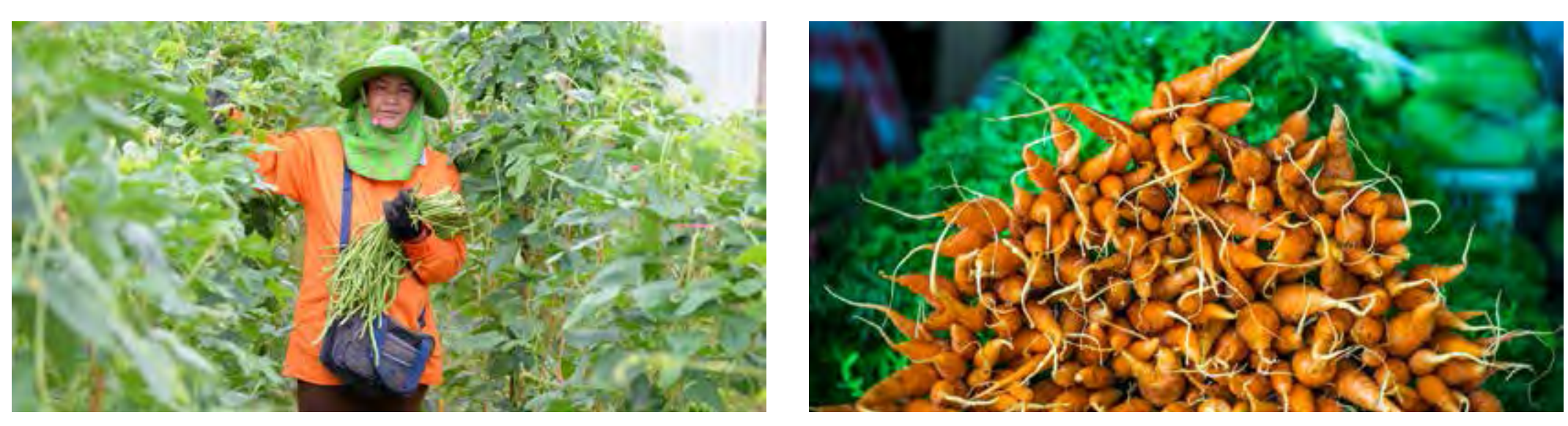
An important environmental initiative, which runs parallel to the economic corridors program, and is based in ADB's Thailand Resident Mission in Bangkok, concerns the preservatio or rehabilitation of biodiversity corridors and biodiversity conservation landscapes. The pattern and pace of developmen in the GMS have been such that natural ecosystems have come under pressure and biodiversity under threat. Outside the mosaic of protected areas in the GMS, the habitats of important and rare wild animals are shrinking, and natural paths of migratio are becoming fragmented. The biodiversity corridor initiative is attempting to join together these habitat fragments, and both preserve and rehabilitate important biodiversity landscapes. There is a particular focus on transboundary conservation efforts, which requires bilateral cooperation and commitment from pairs of GMS states, as well as the synchronization of legal frameworks. In the GMS, there are nine landscapes which have been identified as having particularly high biodiversity value, of which six have been selected for pilot projects to restore habitat linkages and corridors. In Thailand, the biodiversity conservation corridor is located in the Tenasserim Range in western Thailand, between the Western Forest Complex and the Kaeng Krachan Complex.

Climate-friendly agriculture and food safety are among the key environmental objectives of the GMS Core Agriculture Support Program, Phase II, which is implemented by ADB's Working Group on Agriculture, the Secretariat of which is based in Bangkok. The program was originally intended to run from 2011-2015, but
ADB-Thailand Partnership as a Regional Development Partner

Thailand has made the transition from a lower-to a middle-income country in 2011, and aspires to join the ranks of the high-income countries by the year 2026. At the same time, Thailand has targeted a shift from being a recipient of development assistance to becoming a donor and regional development partner, a strategy that was formalized in 2003 withits "Forward Engagement" policy Thailand has two cooperation agencies to take this strategy forward. The Neighbouring Countries Economic Development Cooperation Agency (NEDA) and the Thailand International Development Cooperation Agency. NEDA, as a new agency, needed to develop the institutional capacity to identify, appraise, and finance complexinvestment projects, and thus, in 2006 ADB and procedures, human resource capacity, information and communication technology system, as well as strategic planning: In 2015, ADB signed a partnership arrangement with NEDA to enable the agency to carry out joint cooperation programs at the national and work over the previous decades in supporting Thailand's role as a regional development partner. Cooperation will take the form of cofinancing, knowledge-sharing, and capacity development in the fields of transport, energy, urban development, developmen of special economic zones, health, and education. A similar arrangement for joint cooperation between ADB and the Thailand

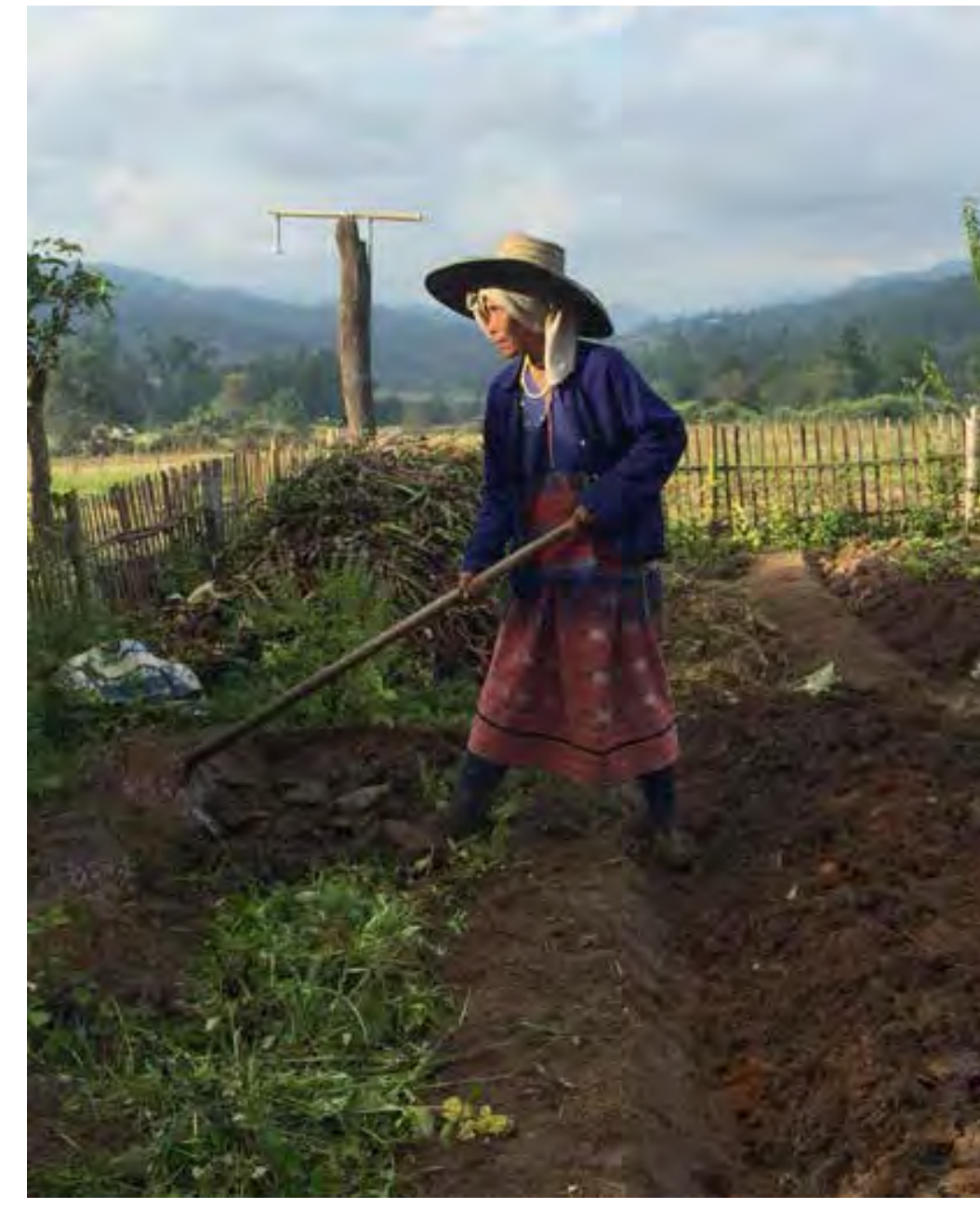

International Development Cooperation Agency has also been developed. ADB has provided TA to both agencies aiming to develop their capacities in project monitoring and evaluation system for better aid effectiveness. 
Box 11: Neighbouring Countries Economic Development Cooperation Agency

The Neighbouring Countries Economic Development Cooperation Agency (NEDA) was formed in 2005 as a public organization under the supervision of the Ministry of Finance. NEDA's main function is as a partner in economic development cooperation with neighboring countries, principally Cambodia, the Lao People's Democratic Republic, and Myanmar, in the fields of transport, energy, urban development, special economic zones, health, education, and capacity-building. It aims to help build regional connectivity in a way that is consistent with the objectives of the Greater Mekong Subregion development program, while also helping to promote a stronger role for the Thai private sector in neighboring countries. Since its inception, NEDA had provided financial and technical assistance projects to a total value of B14.5 billion, and is currently discussing with the Government of Myanmar the provision of a B4.5 billion soft loan for the construction of a 132-kilometer road connecting Phu Nam Ron in Kanchanaburi Province in Thailand with the deepsea port and industrial center of Dawei in Myanmar. As well as providing financial support, NEDA aims to be a channel for academic and other forms of knowledge to help with neighbors' economic development.

Source: Neigbouring Countries Economic Development Cooperation Agency
One of the first projects to be explored under the partnership cooperation between ADB and Thailand's development agencies, and which highlights its relevance to the wider GMS RCI program, is the joint development of corridor towns in Myanmar along the GMS East-West Economic Corridor. Three towns have been selected for parallel financing of the Third GMS Corridor Towns Development Project: the border town of Myawaddy, across from capital of Kayin St capital of Kayn State, and the port cily of Mawlamyne, formerly Moulmein, Myanmar's fourth-largest city and the capital of Mon

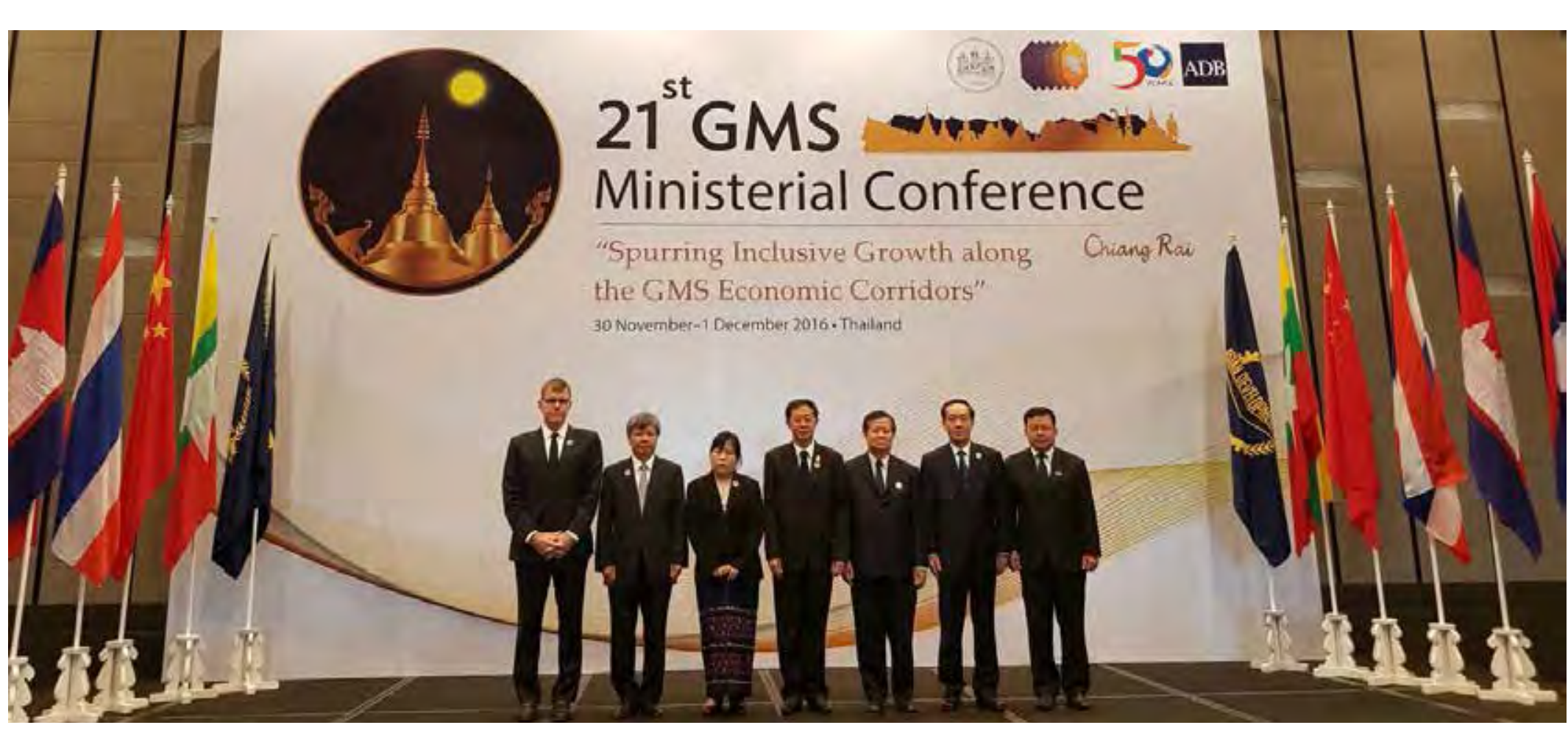

State. As part of the East-West Economic Corridor program the Government of Myanmar is reconstructing Asian Highway One which runs from Myawaddy on the border with Thailand and passes by the other two urban centers in the project. The proposed collaborative project seeks to enable these towns to capitalize on their location within the East-West Economic Corridor, and will help improve access to sustainable urban services such as water supply and solid waste disposal. The project, if successful, within the Prime Minister's Office, where it was established in 1964. TICA includes partnership programs with countries in Australasia, the Americas, Europe, and other parts of Asia, as well as some international organizations such as the United Nations. TICA has, as one of its aims, to serve as a bridge for fiscal year 2014 totalled B305 million.

Source: Thailand International Development Cooperation Agency

ADB support to Thailand as a regional development partner has continued over the past decade through knowledge sharing, capacity development, and parallel financing. 
PART III: TOWARD THE FUTURE

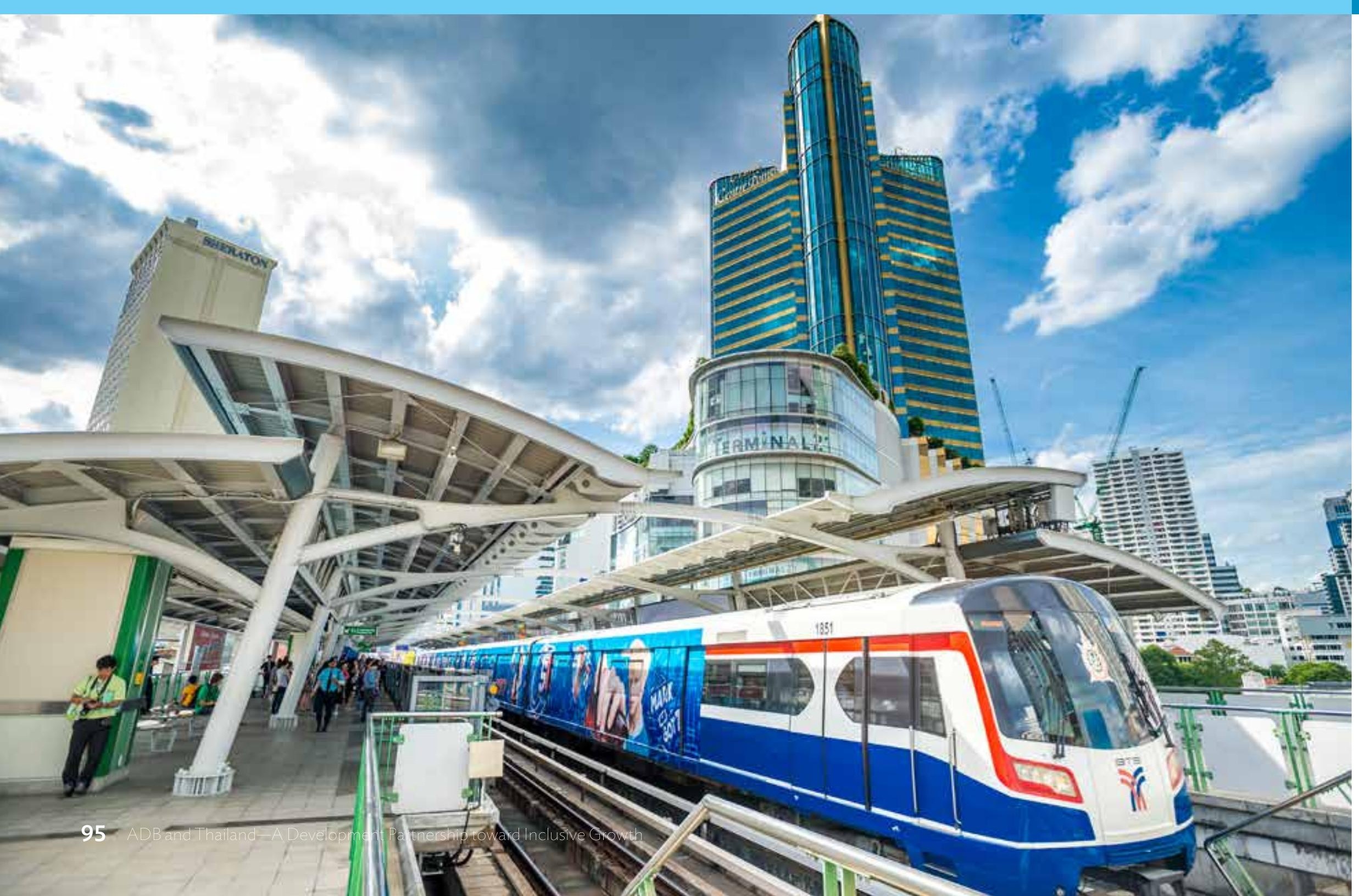

ADB has made a very significant contribution to Thailand's deconcentration, and improvements to the welfare of urban and development during the course of its 50 years' involvement rural citizens alike. ADB has provided substantial assistance to with the country, investing almost $\$ 8$ billion in the process, Thailand during periods of economic crisis and, in partnership with in addition to billions more in the GMS, which has benefited the Government of Thailand, has also contributed significantly Thailand considerably. It has helped finance the construction to essential public sector and financial market reforms, and to and improvement of essential infrastructure, which has provided sustainable development. a platform for continued economic growth and efficiency, spatial
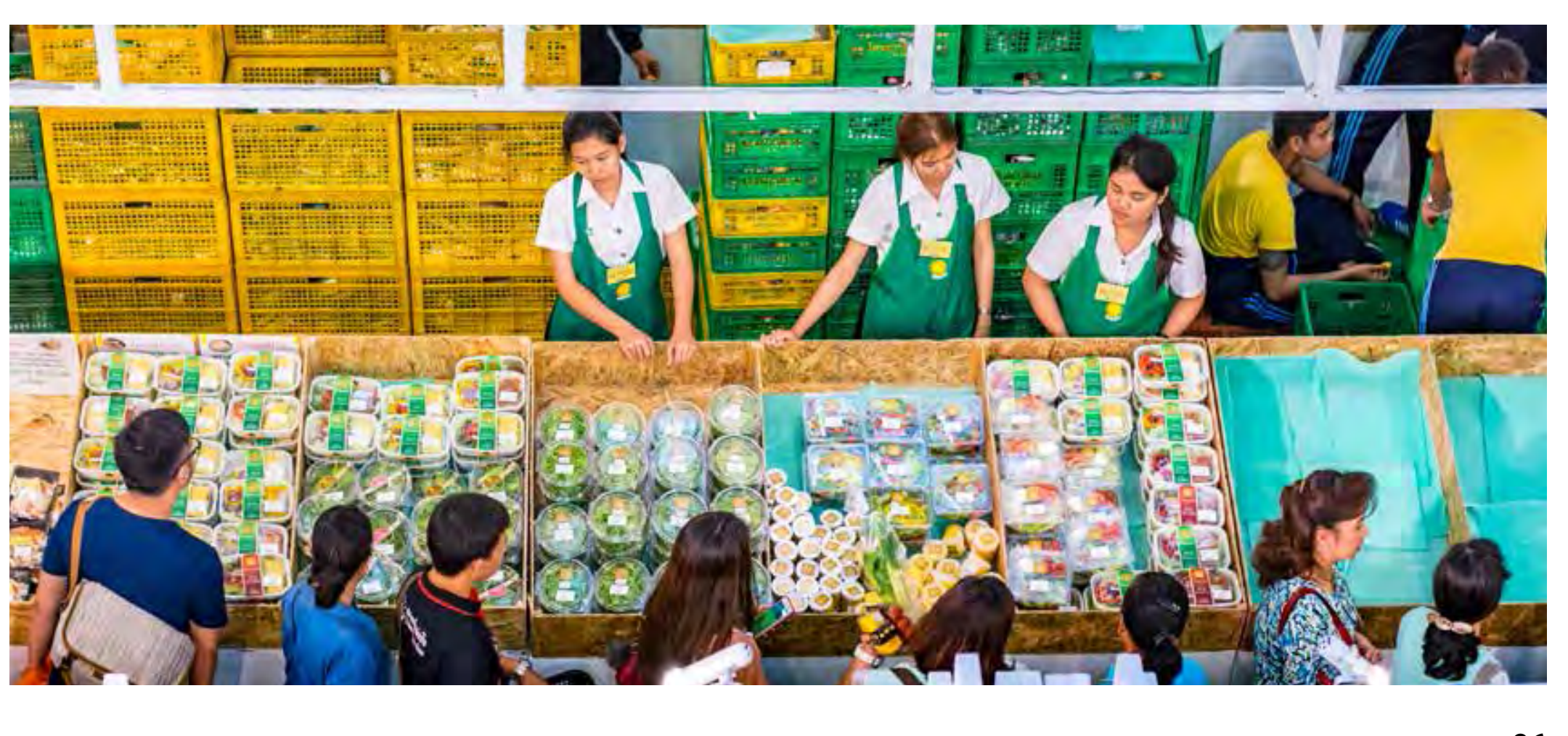
10: ADB Cumulative Lending Grants, and Technical Assistance by Sector and Nonsovereign Financing, 1966-2015

$\begin{array}{lcccr}\text { Sector } & \begin{array}{c}\text { Number of } \\ \text { Project }\end{array} & \% & \begin{array}{c}\text { Total Amount } \\ \text { (\$ million) }\end{array} & \% \\ \text { Agriculture, natural resources, and rural development } & 43 & 15.64 & 420.99 & 6.29 \\ \text { Education } & 14 & 5.09 & 164.70 & 2.46 \\ \text { Energy } & 57 & 20.73 & 2,532.75 & 37.82 \\ \text { Finance } & 33 & 12.00 & 1,058.43 & 15.81 \\ \text { Health } & 5 & 1.82 & 502.45 & 7.50 \\ \text { Industry and trade } & 9 & 3.27 & 91.63 & 1.37 \\ \text { Multisector } & 9 & 3.27 & 4.49 & 0.07 \\ \text { Public sector management } & 34 & 12.36 & 15.56 & 0.23 \\ \text { Transport } & 40 & 14.55 & 1,299.79 & 19.41 \\ \text { Water and other urban infrastructure and services } & 31 & 11.27 & 605.82 & 9.05 \\ \text { Sovereign financing: } & 275 & 100.00 & 6,696.62 & 100.00 \\ & & & & \\ \text { Nonsovereign financing: } & 18 & & 1,172.08 & \end{array}$

Source: Asian Development Bank

\section{LESSONS LEARNED}

Some important lessons have been learned which help lay the groundwork for future partnership between ADB and Thailand. A key to the success of ADB operations in Thailand has been its ability to respond flexibly to a demand-driven agenda. The development landscape has evolved quite rapidly, and so the architecture of development assistance, similarly, has had to Thailand, and the global context within which it is placed, have changed quite rapidly. The path toward development has not always been smooth, however, the characteristic resilience of the Thai nation, coupled with financial support, TA, and support for crucial reforms from ADB, has helped the country to emerge with a stronger platform for future development. ADB has developed a reputation in Thailand as an honest broker of knowledge, a conduit for international best practice, and a trusted lever of good governance. Staff at the TRM have also nurtured strong working relationships with key public and private sector stakeholders, which has underpinned the efficiency of repeat business in core economic sectors. As Thailand is aspiring toward the status of

Thailand has received $\$ 7.8$ billion for ADB loans, grants, technical assistance for sovereign and nonsovereign financings sovereign and
since 1966-2015.

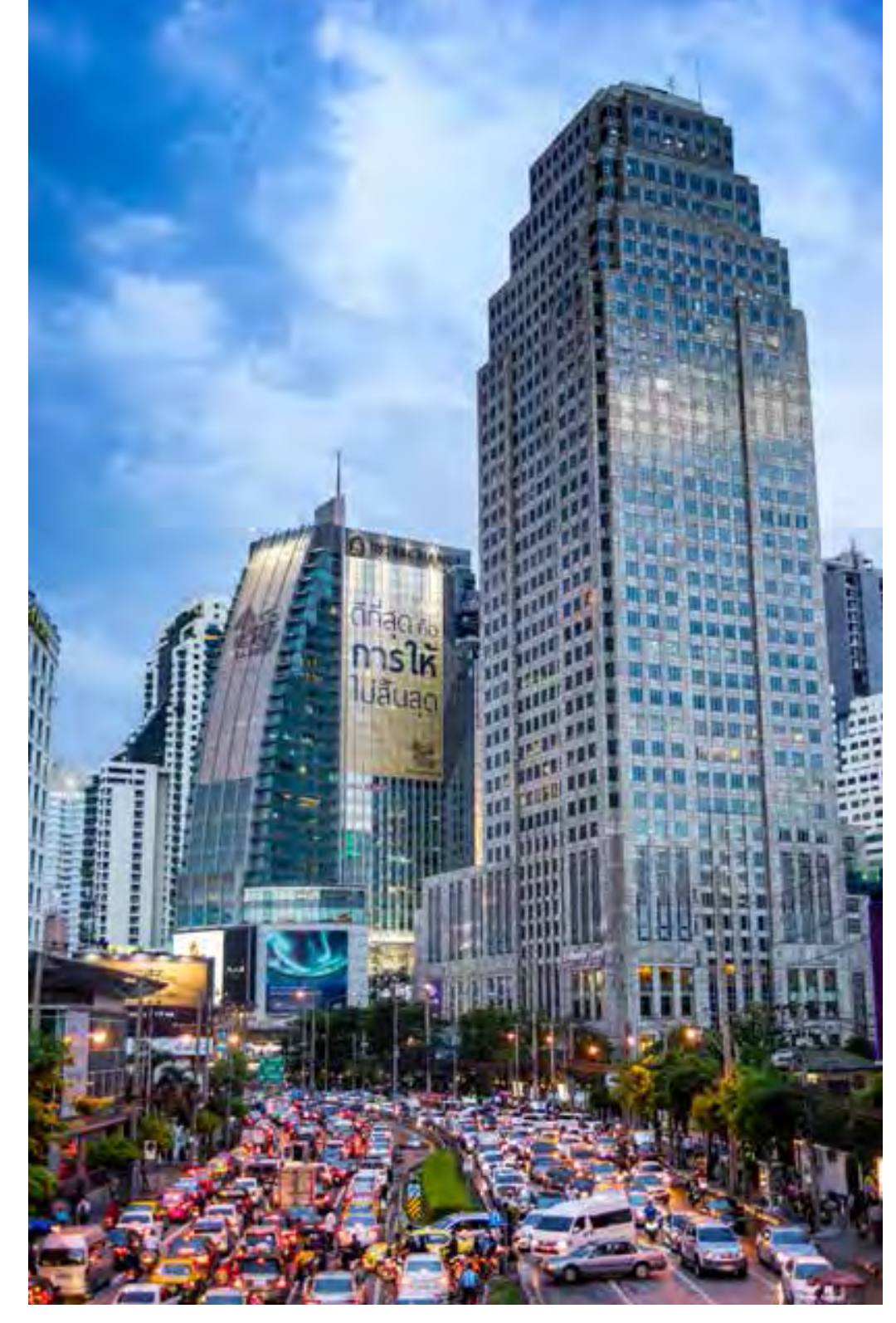

OWARDTHEFUTURE 98 
high-income country, there is a need for ADB to continue its response with innovative packages of financial support allied to world-leading TA.

\section{CHALLENGES}

Despite Thailand's impressive development achievements over the last 50 years, there is still plenty of work to do in terms of broadening and deepening the country's development. The challenges include stubborn pockets of poverty, regiona disparities, environmental degradation and depletion of natural resources, energy security, and economic competitiveness dynamic global and regional contexts. Considerable progress has been made with regard to regional cooperation, but work remains to be done on full integration. There is an urgent need to continue the upgrading of the country's human resources, research capacity, and education system if Thailand is to avoid the middle-income trap-the slowing of growth brought about by a failure to move up the value chain into innovation-driven realms of production. Thailand must also find welfre solutions to an aring society, and otherwise strengthen the social safety net.

From ADB's point of view, the principal challenge is adjusting its business modalities to match Thailand's status as a MIC.

\section{THE WAY FORWARD}

As in the past, the precise shape and form of the partnership between ADB and the Government of Thailand will be negotiated and agreed between the two sets of parties, based on the twelfth national plan and ADB's Strategy 2020. Discussions might focus on some of the following key areas:

$\mathrm{RCl}$ will continue to be a priority focus, given Thailand's strategic position as a regional hub and the centrality of RCI to ADB development agenda. ADB will continue to partner with Thailand to help neighboring countries. Emphasis will be placed on seeking to ensure th collective development potentiat of regiona realized. The recent opening up of Myanmar provides a timely opportunity for intensifying the process of $\mathrm{RCI}$.

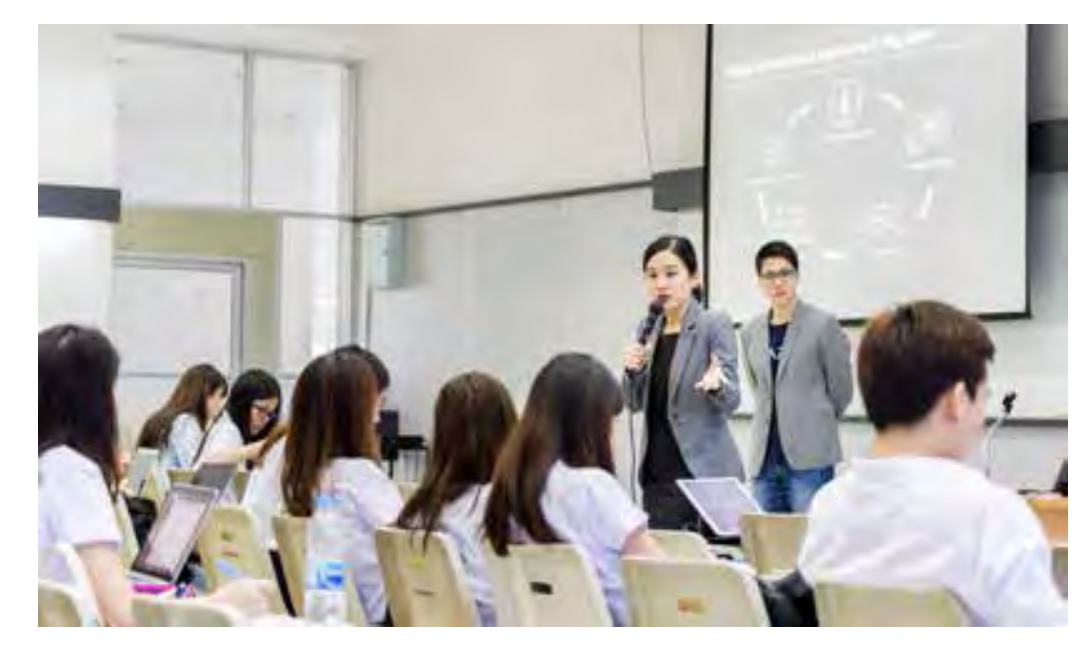

Building on past work in the field of renewable energy and other climate-friendly innovations, ADB aims to focus on cutting edge, niche, and pioneering investments, helping Thailand explore new paths toward sustainability and competitiveness that commercia financial sources may be reluctant to back, but which are essential to Thailand'spath toward future growth. ADBcanuse its knowledge resources and strong credit rating to underpin confidence at the vansuard of future development ADB will continue to play a role

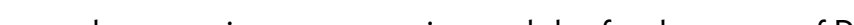

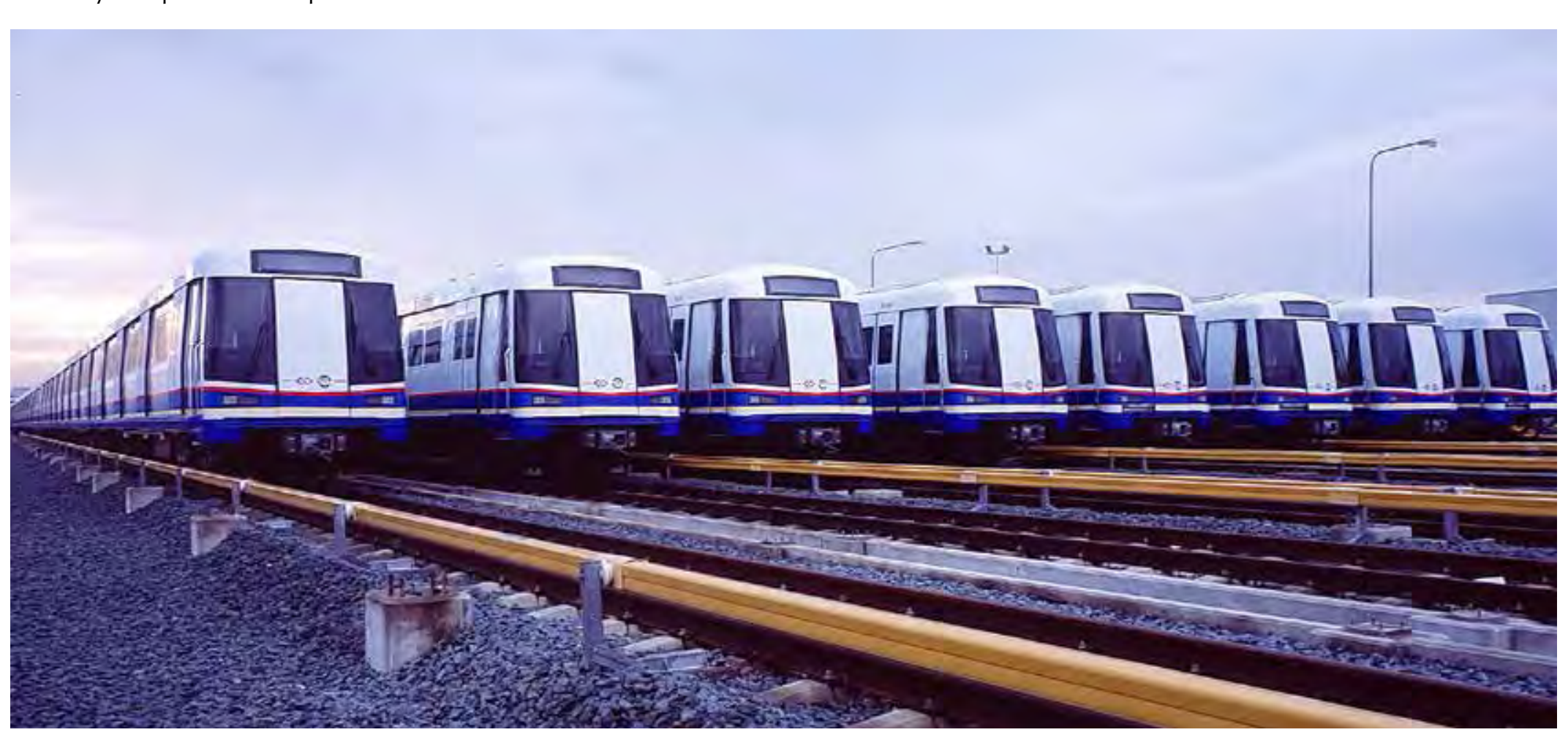

Photo Credit: Bangkok Expressway and Metro Public Company Limited aEN ic and social sectors at the national and subnational levels. ADB will also continue to lend support to the strengthening of Thailand's infrastructure development and natural ecological ADB stands ready to assist Thailand in adopting the Tha Economy 4.0 model of development, which would help with the transformation of the country toward a value-based economy, in the process avoiding the middle-income trap. The building of systems, with a particular emphasis on river basin management. 
ovative finance and financial technology (fintech) and a means of strengthening financial inclusion, smart farming and smart enterprise, high value-added services, creative culture, and so on will require considerable investment in human resources, technology, worker skills, and innovation capacity. ADB will provide financial support to Thailand to enhance research and technology, as well as improve innovation management to accelerate inclusive and sustainable economic development, and contribute to improving overall living conditions. ADB will also continue to use its knowledge resources to underpin good governance, which the government recognizes as an essential ingredient of competitiveness, justice, and inclusive and green growth.

\begin{abstract}
ADB will continue to develop innovative financing products and smart knowledge solutions commensurate with Thailand's status, and its effects here may serve as a model of other countries seeking to make the same transition from an upper MIC to a highincome country.
\end{abstract} A the relationships which have een established with public bodies and, increasingly, private sector entities since the formation of ADB's TRM. These include sustainable energy, with a focus on rooftop solar panels and energy efficiency, the biocultivation of increasingly scarce natural resources, and building on Thailand's leading role in organic and safe food production, as well as leading the dissemination of such echnologies to neighboring countries.

The rail system will also provide an important focal point for ADB's partnership with Thailand, including continued involvement in the expansion of the MRTS, and helping Thailand to accelerate rail connectivity within the country and with its neighboring countries.

New directions might include helping Thailand to strengthen the sustainability of its rapidly growing tourism sector, lending assistance to the public health and education sectors, and supporting both biomedical and biotechnology development.

ADB will continue to develop innovative financing products and smart knowledge solutions commensurate with Thailand's status, and its effects here may serve as a model of other c seeking to make the same transition from an upper MIC to a highincome country. ald

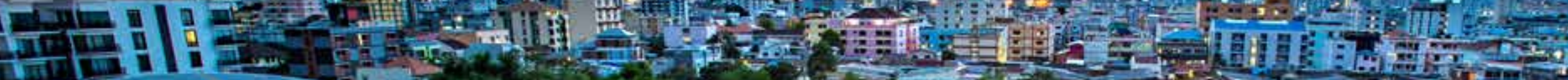
HIIII I

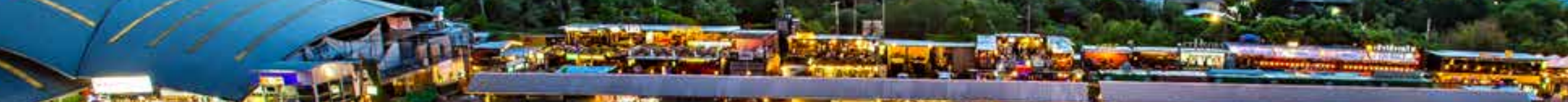
30 रे
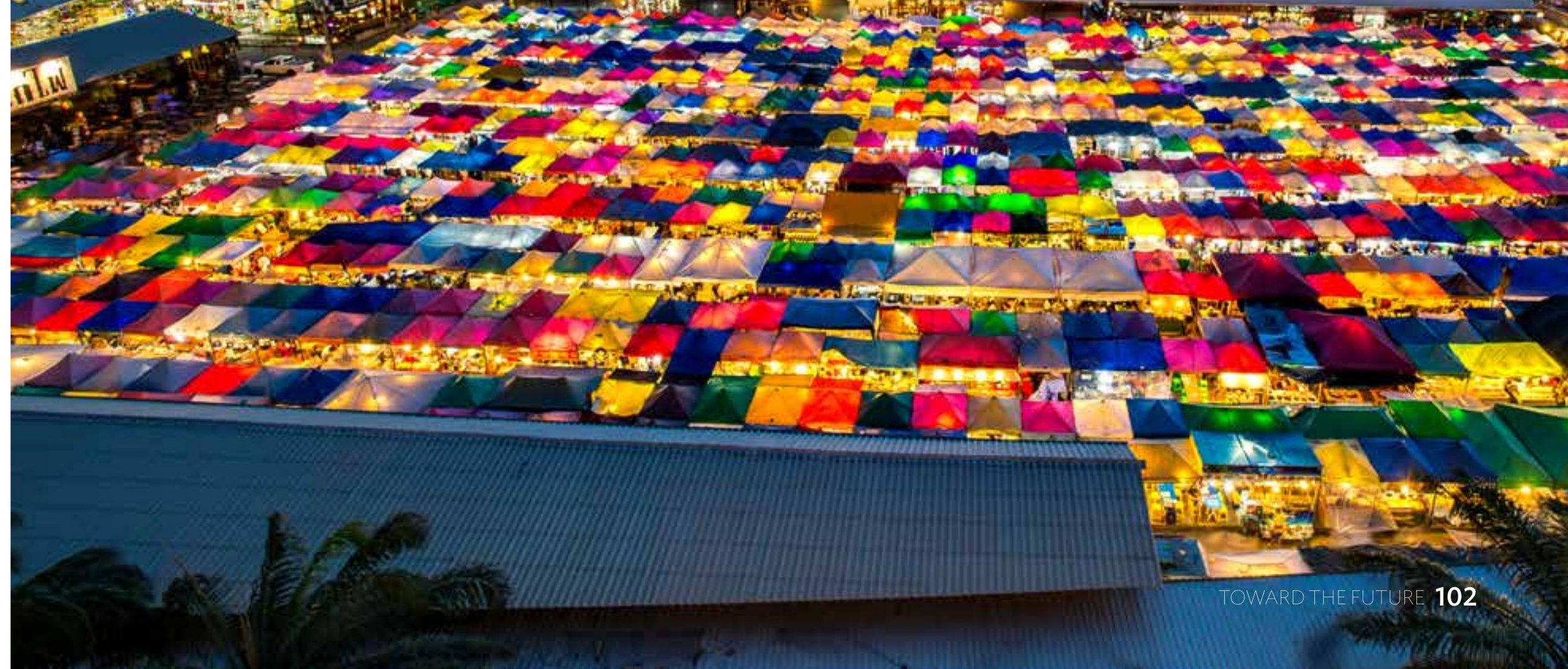


\section{REFERENCES}

Asian Development Bank. 1992. A Generation of Growth: The Asian Development Bank's First 25 Years. Manila:

Asian Development Bank. 2015. Energy Outlook for Asia and the Pacific. Manila.

Bird, Kelly, Kelly Hattel, Eiichi Sasaki, and Luxmon Attapich. 2011. Poverty, Income Inequality and Microfinance in Thailand. Southeast Asia Working Paper Series, No. 6. Manila.

Board of Investment. 2014. Thailand's Alternative Energy. Thailand Investment Review. Thailand: Board of Investment. www.boi.go.th/tir/ issue/201403_24_3/42.htm (accessed 23 November 2016).

Burke, Paul J. and Zsuzsanna Csereklyei. 2016. Understanding the Energy-GDP Elasticity: A Sectoral Approach. CAMA Working Paper No. 45.2016. Canberra: Australian National University, Crawford School of Public Policy, 4.

Economist Intelligence Unit. 2009. Global Microscope on the Microfinance Business Environment, 2009. London: EIU Center for Financial Inclusion. graphics.eiu.com/upload/eb/Microfinance_ENG_WEB_Sept\%2025.pdf (accessed 19 November 2016).

Government of Thailand, Ministry of Energy. 2011. Thailand: 20-Year Energy Efficiency Development Plan, 2011-2030. Thailand: Ministry of Energy, 2-1.

Government of Thailand, Ministry of Energy. 2015. Thailand Alternative Energy Development Plan, 2015-2036. Thailand: Ministry of Energy, Department of Renewable Energy Development and Energy Efficiency, 9.

Government of Thailand, Ministry of Energy. 2015. Thailand Power Development Plan, 2015-2036. Thailand: Energy Policy and Planning Office, 2-2.

Tambunlertchai, Kanittha. 2015. Financial Inclusion, Financial Regulation and Financial Education in Thailand. ADB Working Paper Series No. 537. Tokyo: ADB Institute.

Watanabe, Takeshi. 1977. Toward a New Asia. Manila.

White, John. 1970. Regional Development Banks. London: Overseas Development Institute.

\section{ABBREVIATIONS}

ADB Asian Development Bank

AEDP Alternative Energy Development Plan

ASEAN Association of Southeast Asian Nations

BAAC Bank for Agriculture and Agricultural Cooperatives

BCP Bangchak Petroleum Public Company

CTF Clean Technology Fund

DMC developing member country

DOH Department of Highways

EGAT Electricity Generating Authority of Thailand

EPO Fiscal Policy Office

GMS Greater Mekong Subregion

GSB Government Savings Bank

IBRD International Bank for Reconstruction and Developm

IFCT Industrial Finance Corporation of Thailand

IFI international financial institution

$\mathrm{km} \quad$ kilometer

kWh kilowatt-hour

MIC middle-income country

MOPH Ministry of Public Health

MRTS mass rapid transit system

MW megawatt
NEDA Neighbouring Countries Economic Development Cooperation Agency

OECD Organisation for Economic Co-operation and Development

PDMO Public Debt Management Office

PEA Provincial Electricity Authority

PPP public-private partnership

PRC People's Republic of China

$\mathrm{RCl}$ regional cooperation and integration

SET Stock Exchange of Thailand

SFI specialized financial institution

SMC Secondary Mortgage Corporation

SMEs small and medium-sized enterprises

SPP small power producer

SRT State Railway of Thailand

TA technical assistance

TRM Thailand Resident Mission

TICA Thailand International Development Cooperation Agency

VSPP very small power producer 


\section{ADB and Thailand}

A Development Partnership toward Inclusive Growth

Over the past 50 years, the Asian Development Bank (ADB) is proud to have participated in the remarkable transformation of Thailand, one of ADB's founding member countries. Today, ADB supports the addressing of environmental challenges, the building of institutional and operational capacity, and the strengthening of Thailand's international competitiveness. This publication reflects on Thailand's impressive development journey over the past 50 years, and its rise to upper-middle income country status. It is hoped that this publication can also lay the groundwork for future policy directions between ADB and Thailand. As a trusted provider of knowledge and finance, $A D B$ will continue to support sustainable and inclusive growth in Thailand.

\section{About the Asian Development Bank}

ADB's vision is an Asia and Pacific region free of poverty. Its mission is to help its developing member countries reduce poverty and improve the quality of life of their people. Despite the region's many successes, it remains home to a large share of the world's poor. ADB is committed to reducing poverty through inclusive economic growth, environmentally sustainable growth, and regional integration.

Based in Manila, ADB is owned by 67 members, including 48 from the region. Its main instruments for helping its developing member countries are policy dialogue, loans, equity investments, guarantees, grants, and technical assistance.

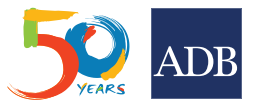

ASIAN DEVELOPMENT BANK

6 ADB Avenue, Mandaluyong City

1550 Metro Manila, Philippines

www.adb.org

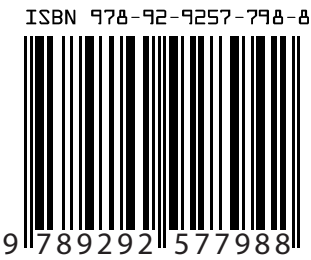

